Bull. Fac. Agric., Cairo Univ., 71: 175-195 (2020).

\title{
DETERMINANTS OF THE DISCONTINUITY DECISION FOR ADOPTING THE COMPOST RECOMMENDED PRACTICES AMONG A SAMPLE OF FARMERS IN KAFR EL-SHEIKH DISTRICT
}

(Received: 30.12 .2020$)$

\author{
By \\ M. F. Ebad-Allah and Hoda M. H. Helil* \\ Faculty of Agriculture,Tanta University and *Agricultural Extension and Rural Development Unite \\ at Kafr El-sheikh, Agriculture Research Center
}

\begin{abstract}
Technological innovations are still effective tools for achieving social and cultural change in many rural societies. This Paper aimed to propose and test a theoretical model for some determinants of the discontinuity decision for adopting the compost recommended practices. To achieve this goal; A sample of 342 farmers were selected in Kafe El-Sheikh. And, Personal interviews were used for collecting the data. Different statistical techniques were used to analyze these data. The most important results indicated that there was no significant relationship between exposure to an extension campaign and the discontinuity decision among the farmers. In addition the results indicated that the antecedent variables have the largest contribution in predicting the tendency of a decision of discontinuity in adopting compost practices more than the process variables. The results also showed that the variable of participating in environmental activities is the greatest important determinant in predicting the discontinuity decision in compost practices in the first and second stage of the logistic regression model.
\end{abstract}

Key words: Agricultural Sustainable Development, Egypt, Decision of Discontinuity, Logistic Regression, Recycling of Agricultural Wastes, Technological Innovations.
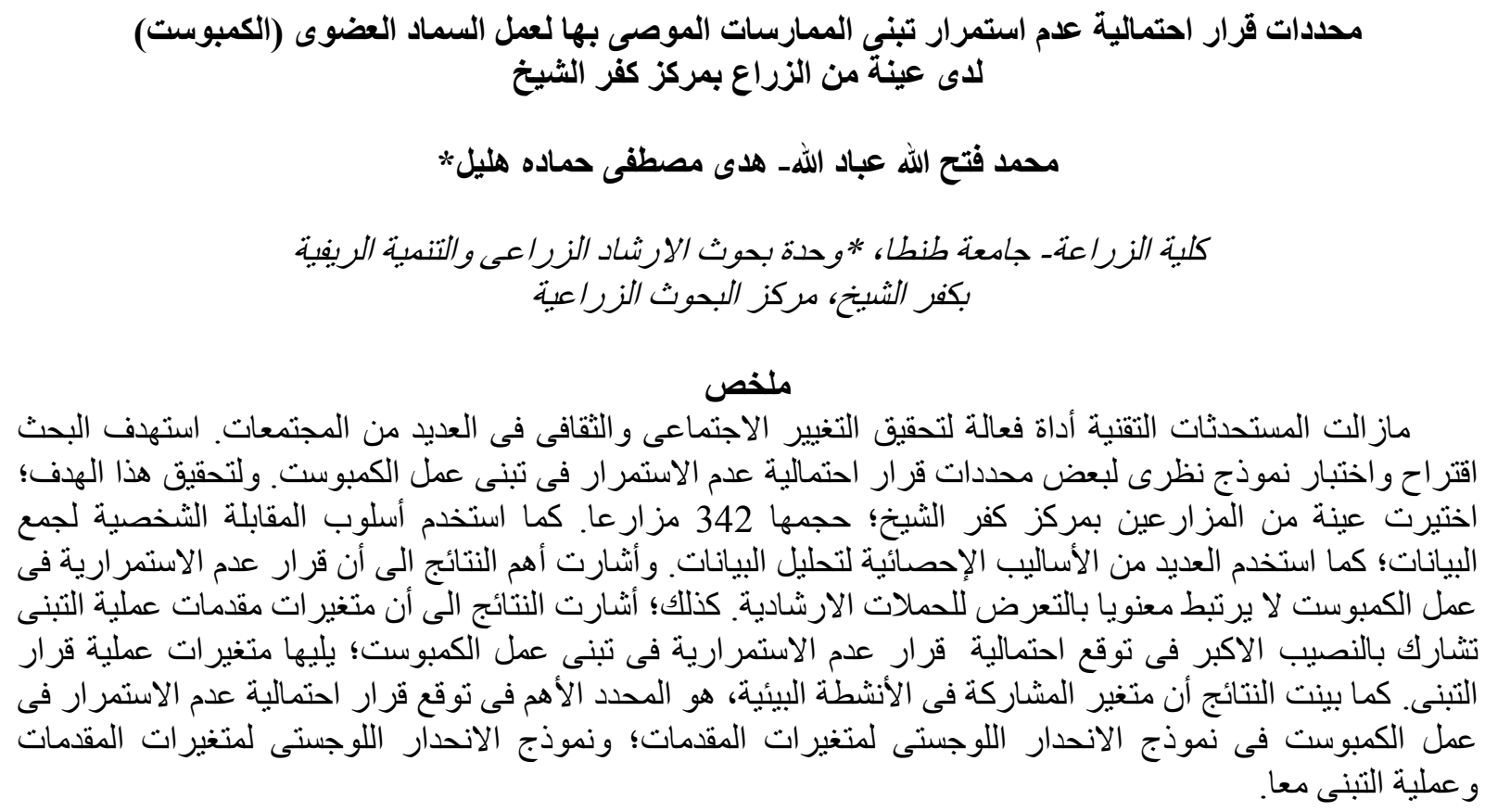
و الزراعية التى ينتمى اليها الزراع تحتاج الى متطلبات

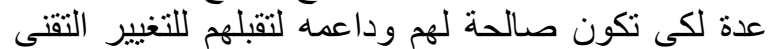

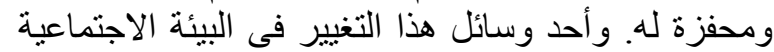

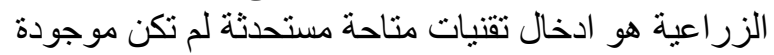

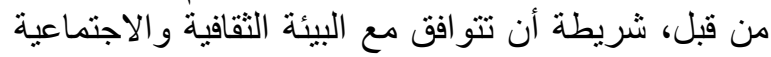

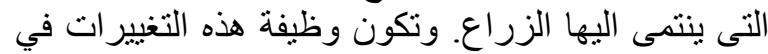

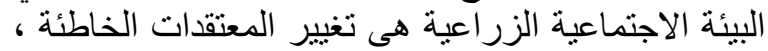

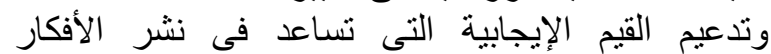

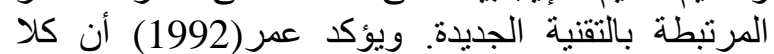
الاستراتيجيتين لإحداث التغيير التقنى مطلوبتينين كحزمة

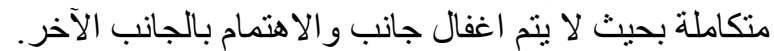
بالإضافة الى ذلك، وقبل الاختيار بين كلا الاستر اتيجيتين

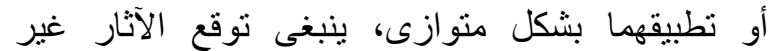

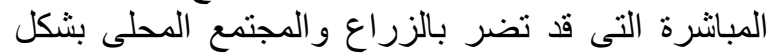

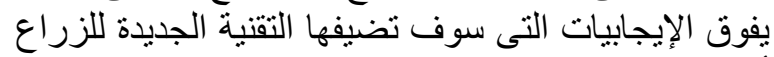

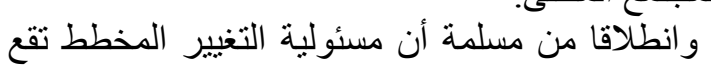

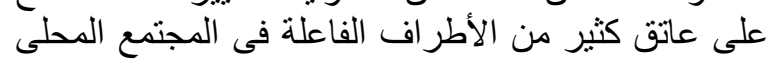

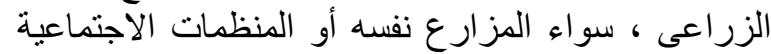

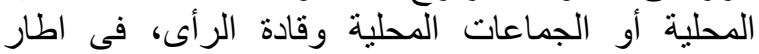

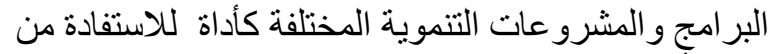

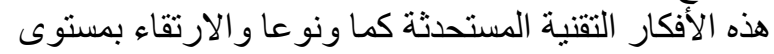

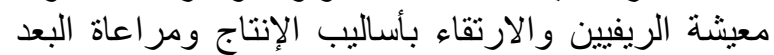

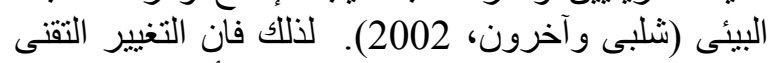

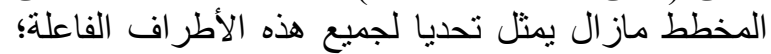

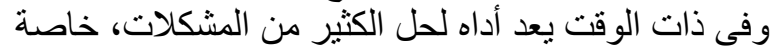

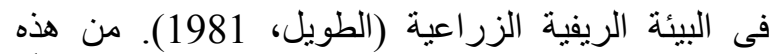

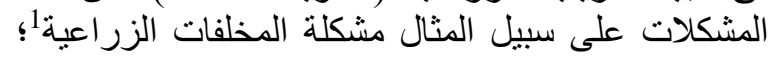

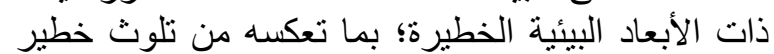

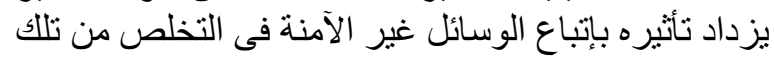

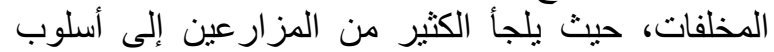
الحرق المباثر كأسهل الطرق لسرعة التخلص من التر بقايا

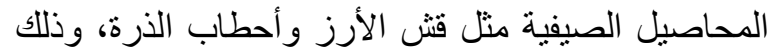

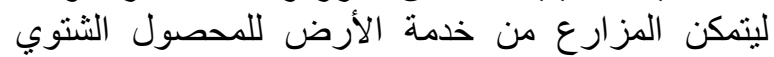

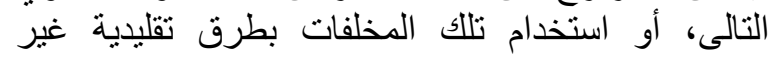

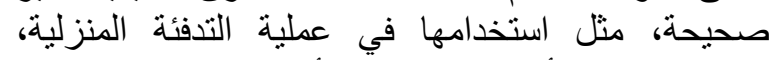

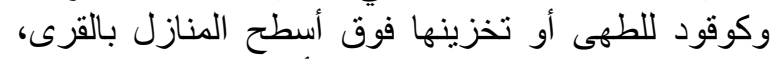

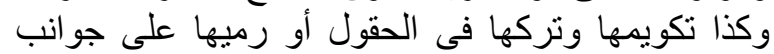

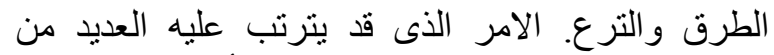

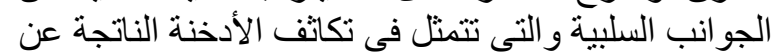
حرق لهذه المخلفات والتى تظهر فى شكل سحابة سوداء، التهاء

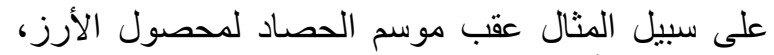
علاوة على أن حرق هذه الدخلفات يؤدى إلى مشكلات

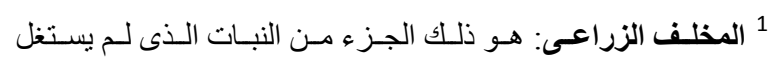

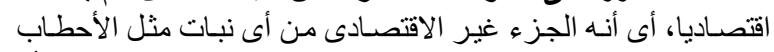

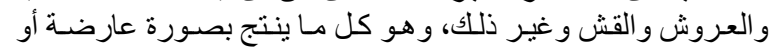

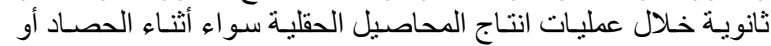

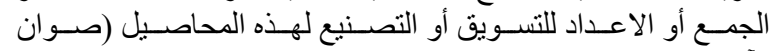
وآخرون، 2010)

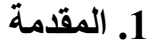

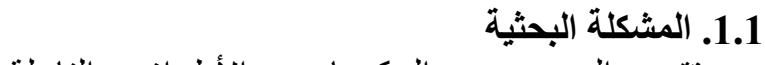

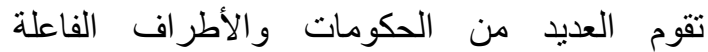

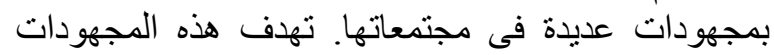

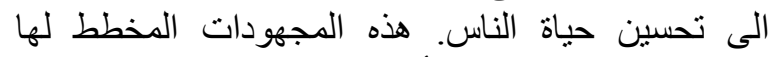

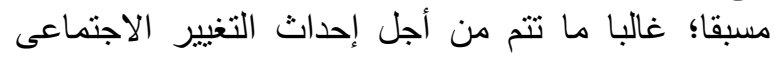

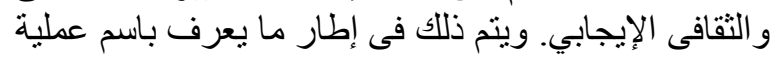

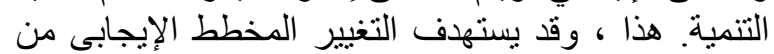

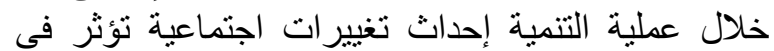

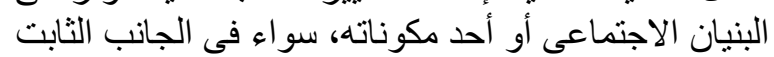

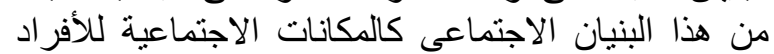

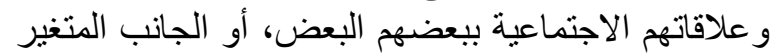

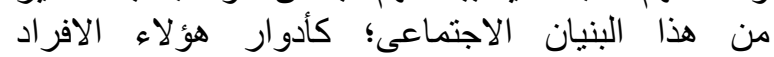

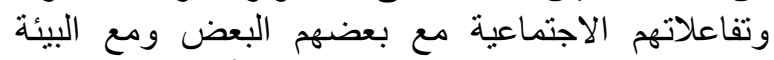

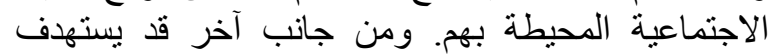
التغيير المخطط من خلاعل عملية التهات التنمية؛ إلى إحداث

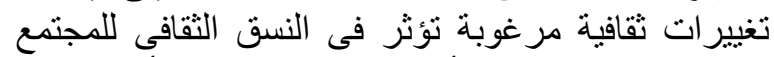

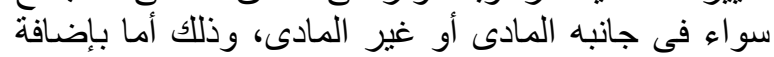

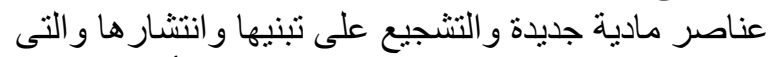

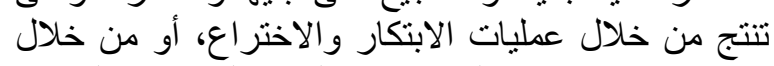

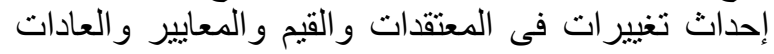

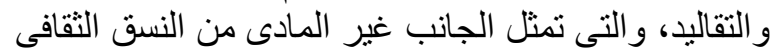

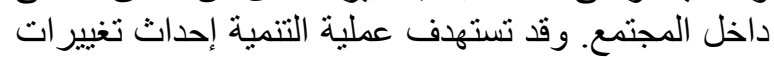
اجتماعية وثقافية لتشمل كل من النسق الاجنماعى والنسق تلنق

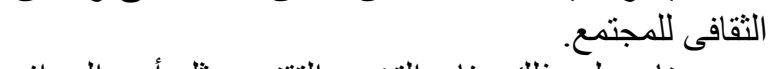

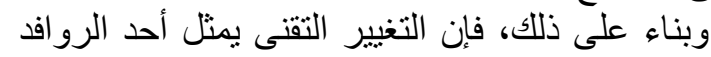

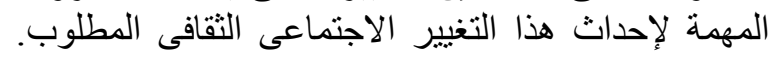

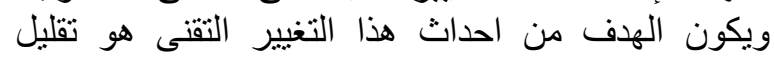

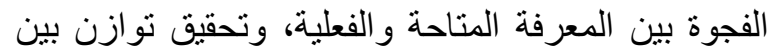

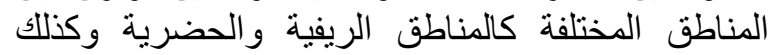
تصحيح الاثار السلبية للتغير غير المخطط أو التقليل من ونا

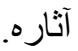

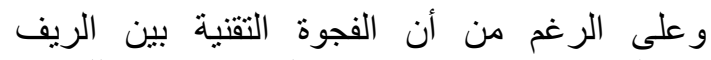

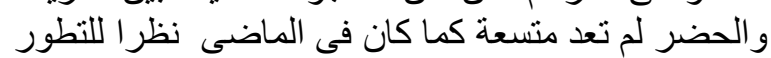

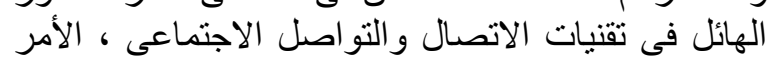

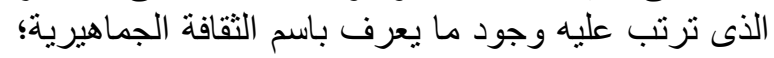

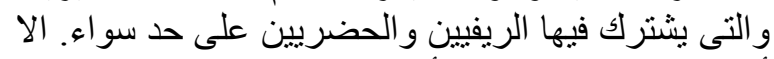

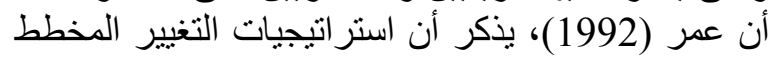

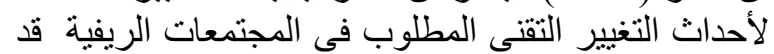

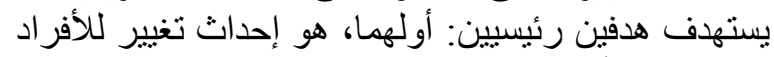

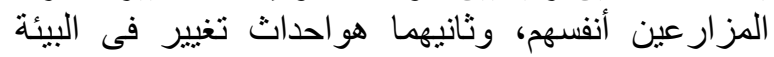

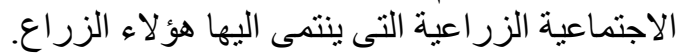

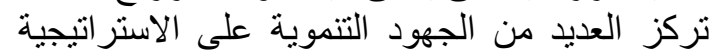

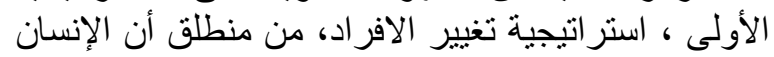

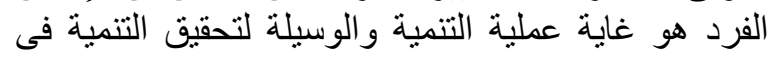

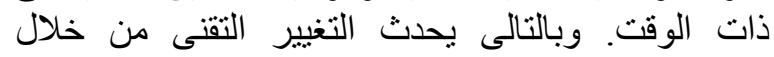

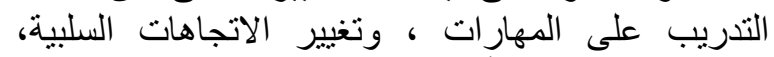

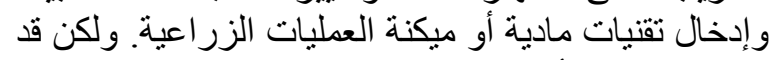
يرى البعض أن استراتيجية تغييز البية البيئة الاجنماعية 


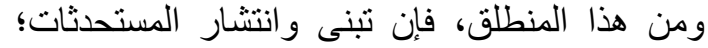

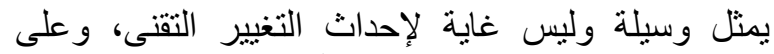

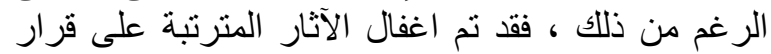

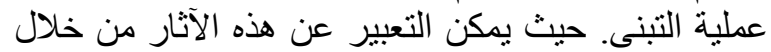

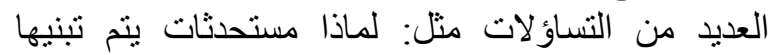

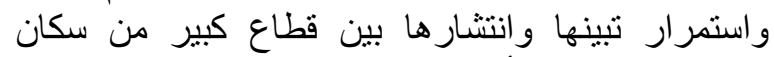

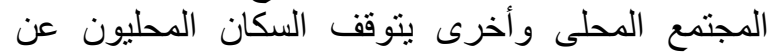

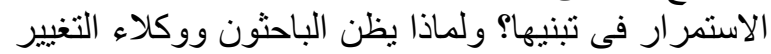

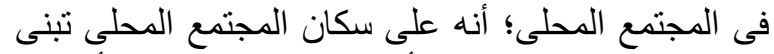

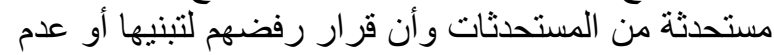

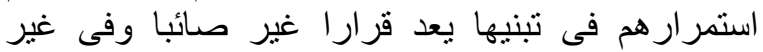

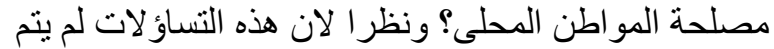

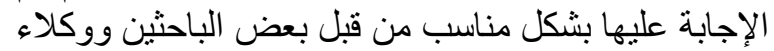

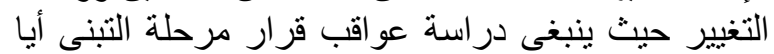

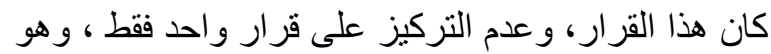

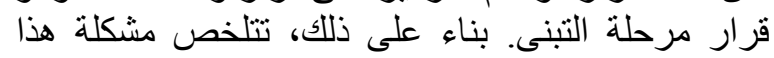

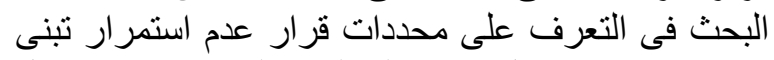

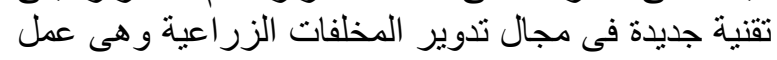
السماد العضوى (الكمبوست).

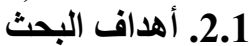
انطلاقاً من المشكلة البحثية ، تتخلص أهداف هذا البحث

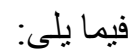
الهذف الاول: بناء نموذج نظرى لبعض محددات قرار

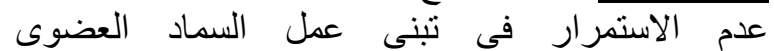

الهـف الثاني: التعرف على العلاقات الثنائية والمتعددة

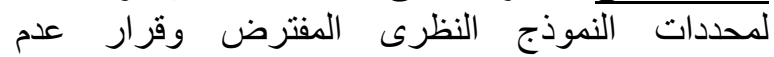
الاستمرار فى تبنى عمل النى السماد العضوى (الكمبوست)، لاى عينة من الزر العي بمركز كفر الثيخ.

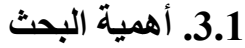

لهذا البحث أهميته من الناحيتين العلمية والتطبيقية.

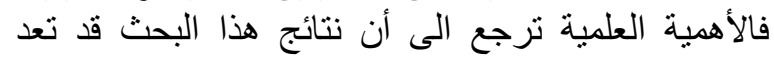

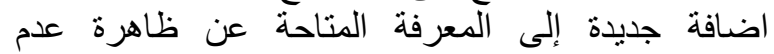

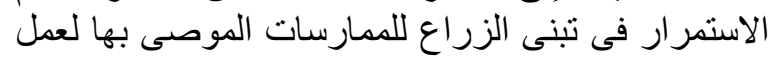

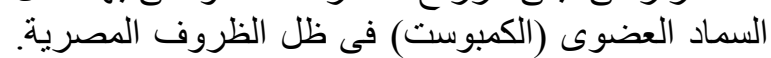

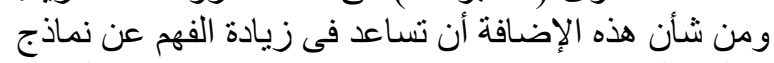

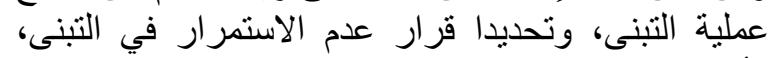

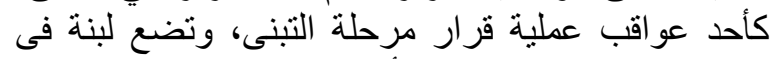

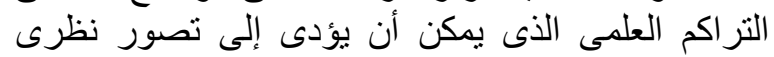

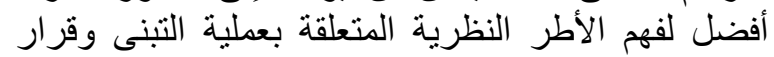
عدم الاستمر ار فيها.

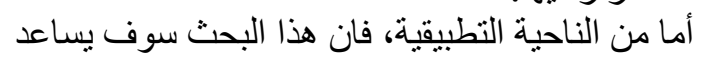

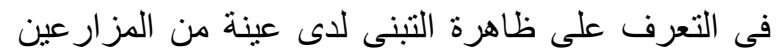

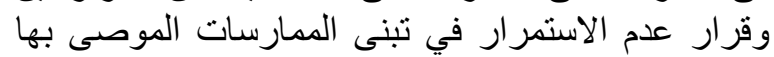

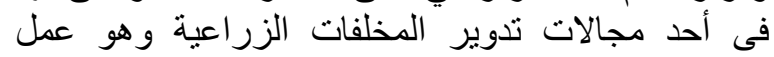

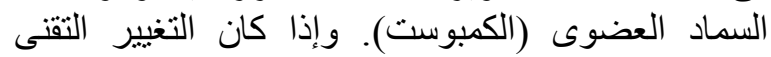

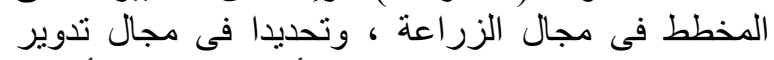

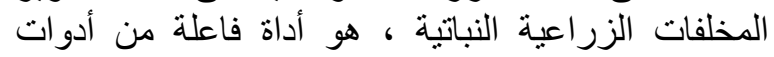
التنمية الزراعية المستدامة، فان الواتية الوقوف على الثى محددات

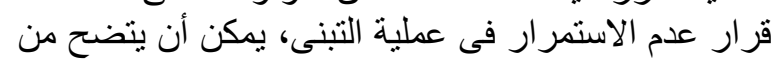

صحية مضاعفة بسبب استنشاق الدخان الملوث بيقايا

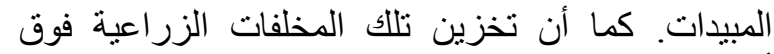

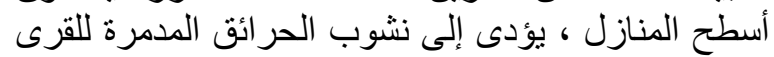

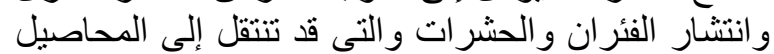
الجديدة فتصيبها. هذه الكميات الهائلة من المخلفات و والممارسات السلبية الهادية

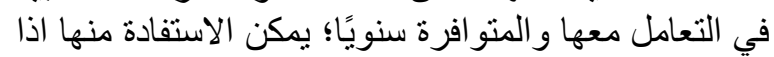

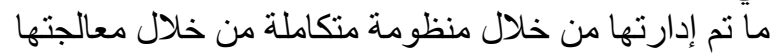

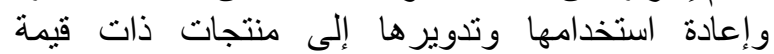

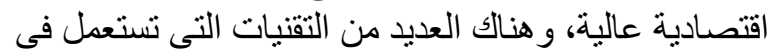

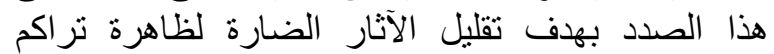

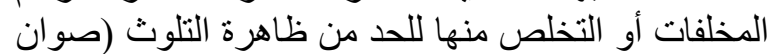

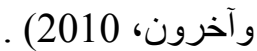

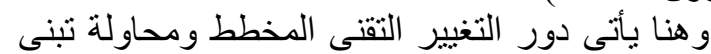

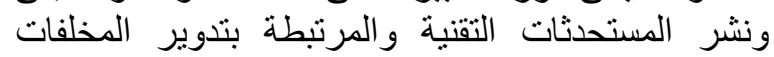

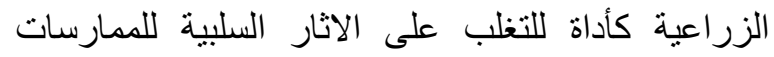

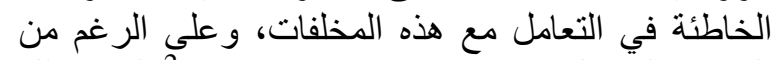

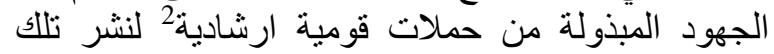

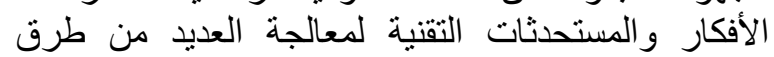

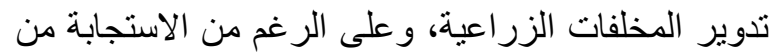

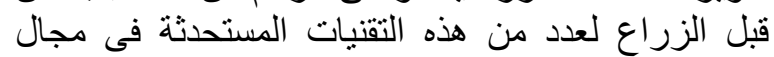

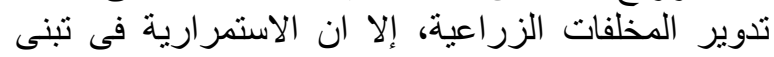

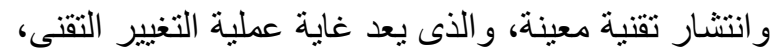

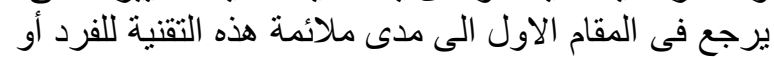

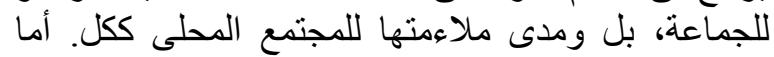

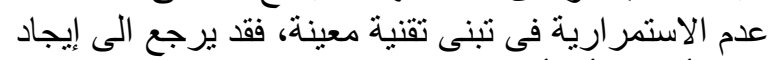

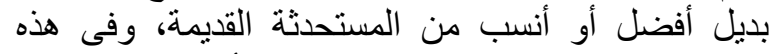

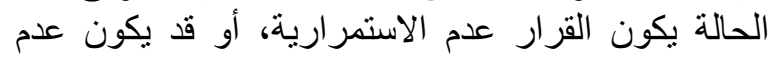

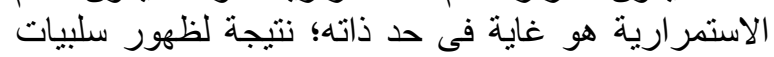
فى التقنية التى تم تبنيها. هذا الاختلاف فى تقبل التغيير التقنى، واتخاذ قرار

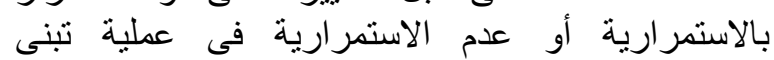

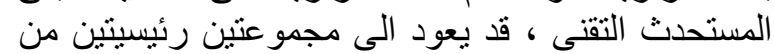

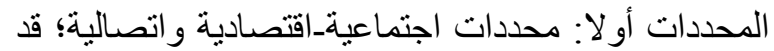

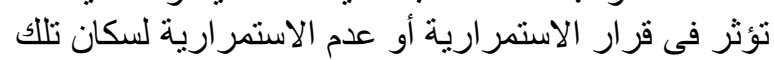

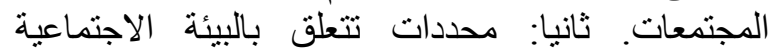

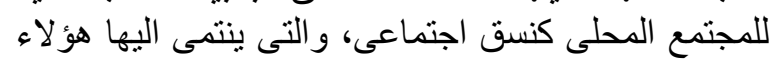

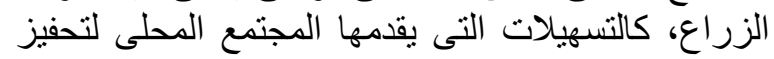

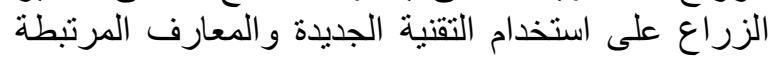

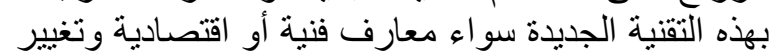

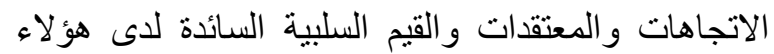

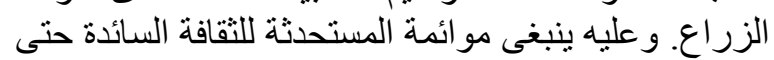

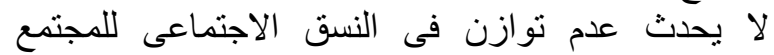

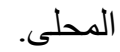

22 الحملة الارشادية: هى نثاط تعليمى مكثن ينتم فى الوقت المناسب،

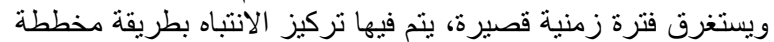
تجاه مشكلة خاصة؛؛ لكى تثير الآنتباه على أكبر مستوى ممكن بالقرية. (Leagans, 1961) 
منها لم يتحقق، أو أن تكاليفها أكبر من العائد منها، أو أن

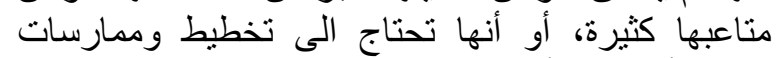

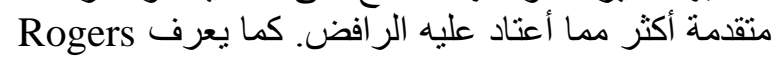

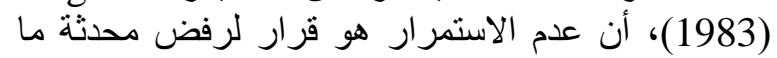

بعد تبنى مسبق لها.

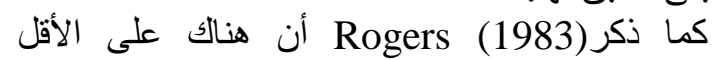
نمطين من أنماط قرار عدم الاستمرار وهما: قرار عار عدم

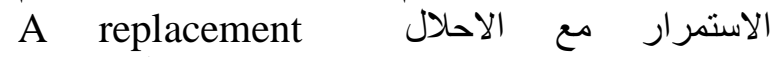
discontinuance

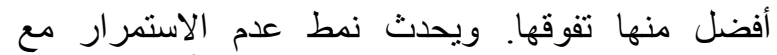
الاحلال نتيجة لان هناك تلان تيارات من الأفكار الجديدة

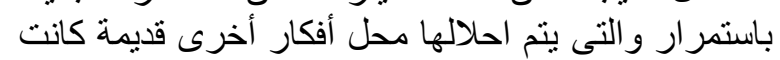

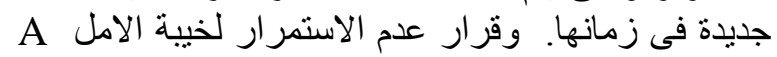
رفض disenchantment discontinuance رفض فكرة ما نتيجة لعدم الرضا لأداء هذه الفكرة. و وهذا

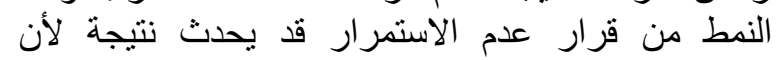

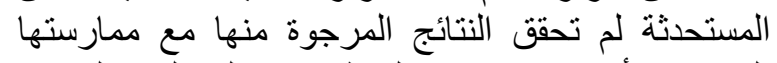

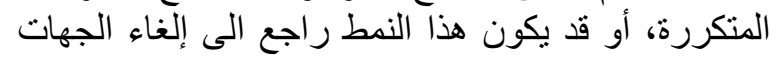

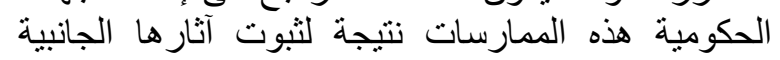

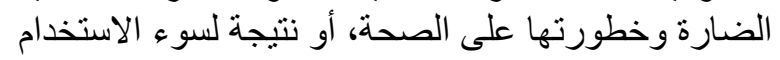

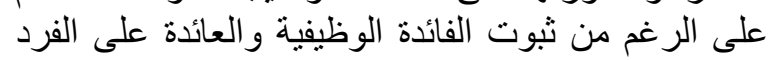
من تطبيق هذه الفكرة.

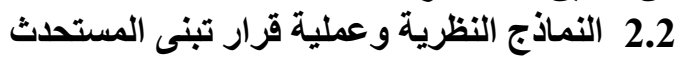

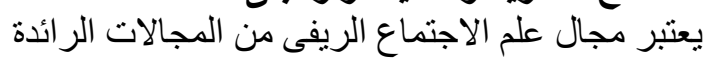

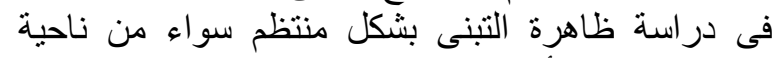

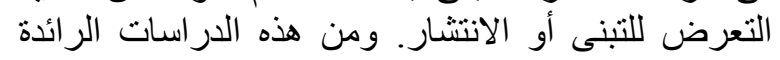

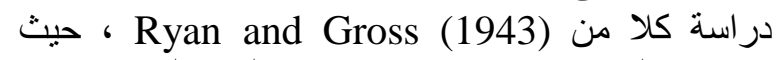
تعرضوا لدراسة تبنى وانتشار تقاوى الذرة الذرة الهجين. بينما

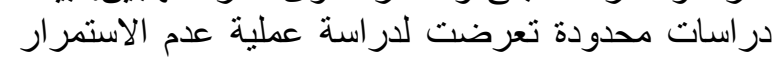

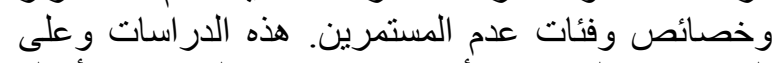

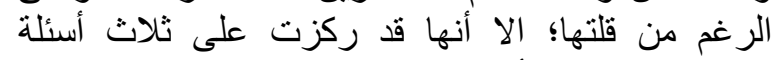

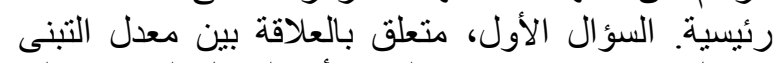

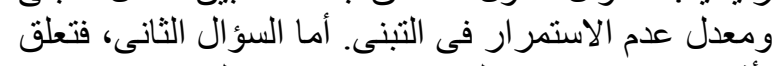

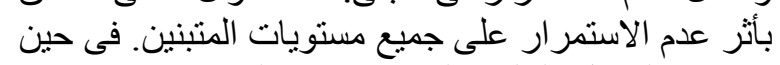

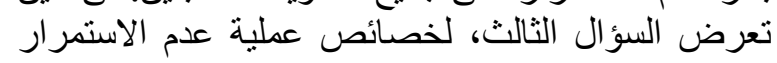

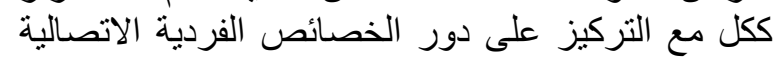

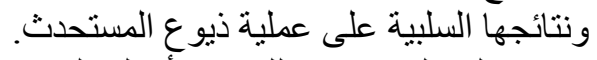

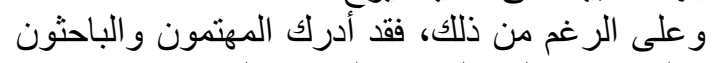

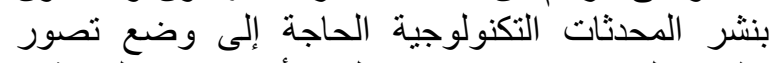

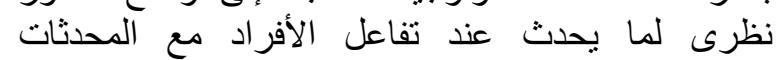

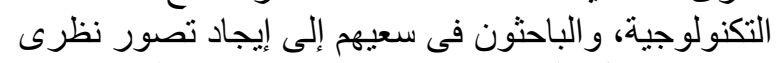

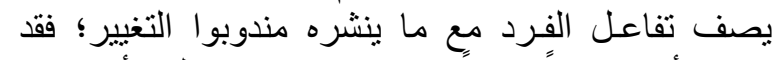

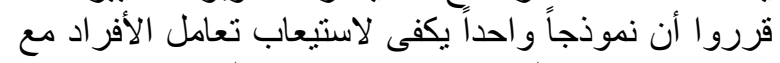

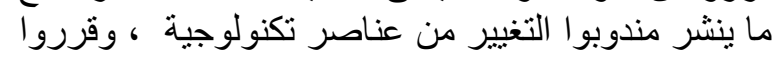

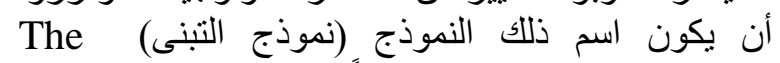

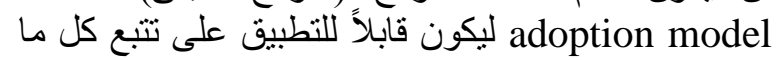
ينت نشره بين الناس من محدثات تكنولوجية لونية.

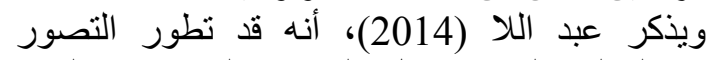

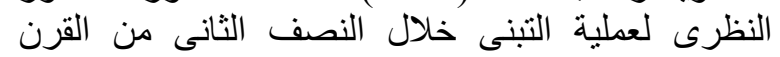
العشرين الميلادى فى ثلاث تيار ات فكرية. التيار الفكرى
اجراء هذا البحث؛ وما يترتب عليه من استكثاف جزئى الإنى

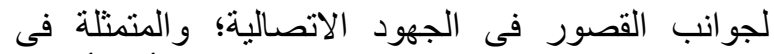

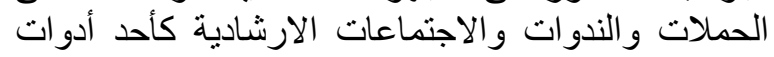

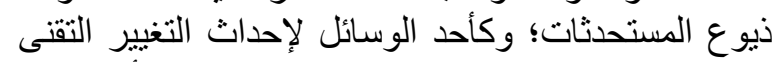

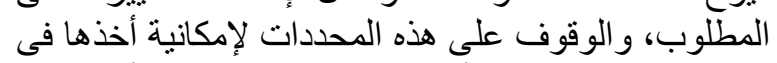

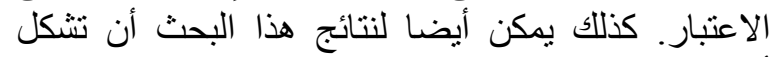

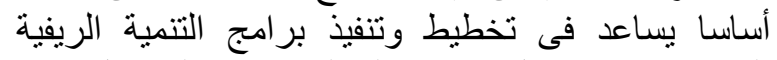

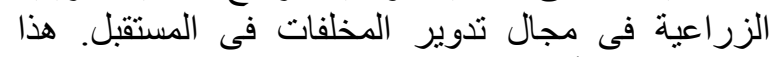

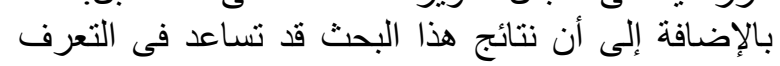

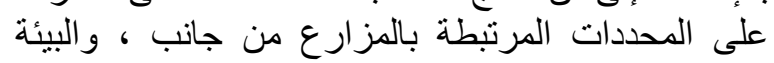

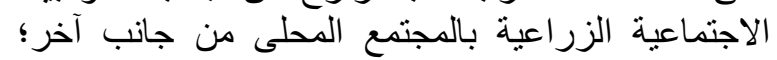

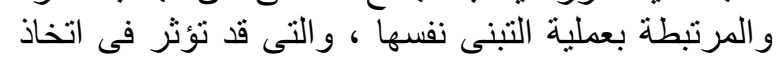

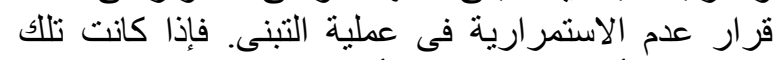

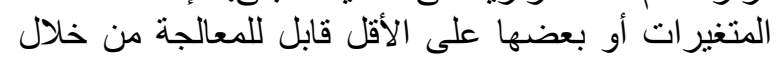

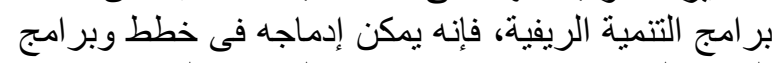

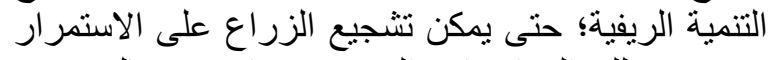

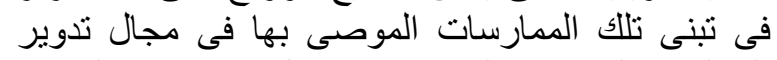

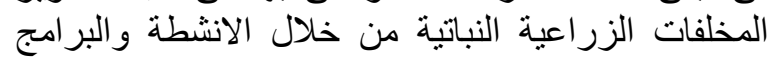
التنموية الريفية المختلفة.

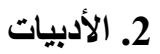

1.2 مفهوم عملية التبنى وقرار عدم الاستمرارية

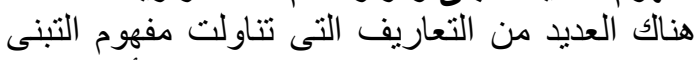

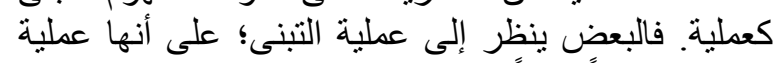

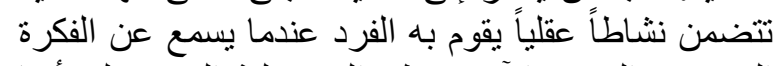

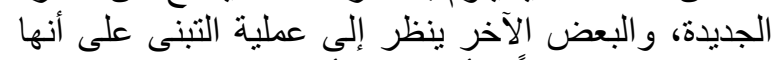

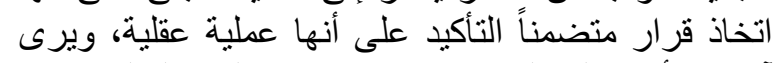

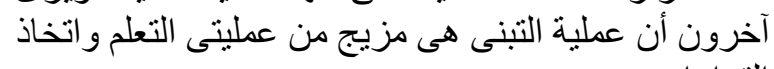

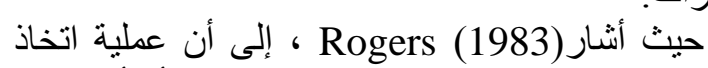

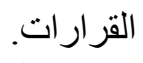

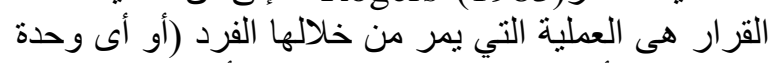

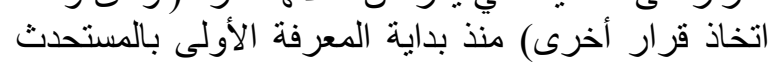

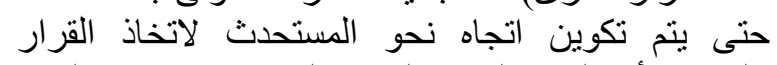

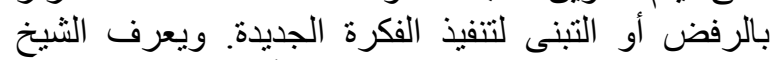

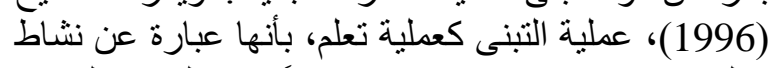

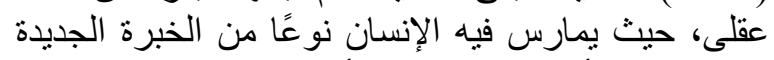

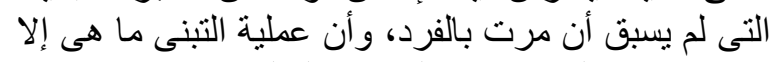

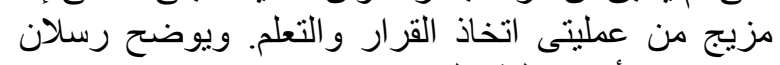

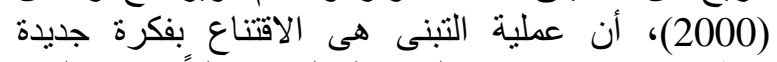

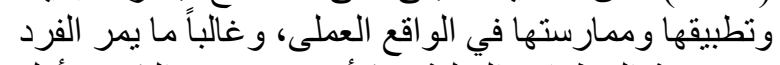

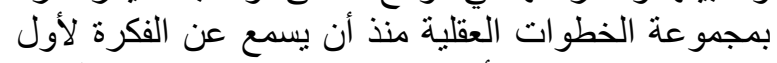

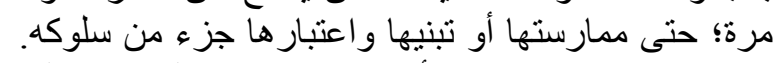

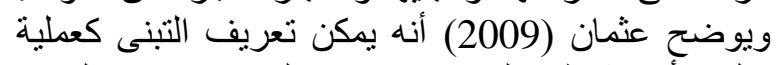
تعلم؛ بأنده نشاط عقان عقلى يمارس فيه الفرد نوع نوع من الخبرة

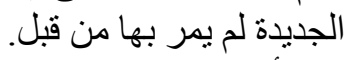

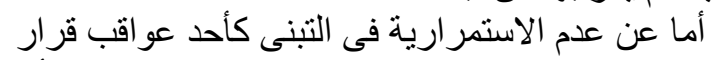

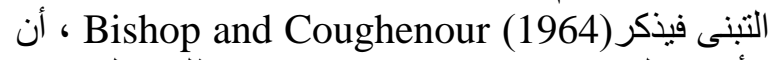

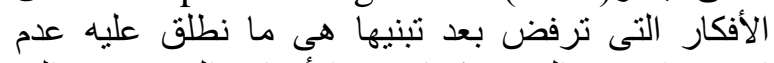

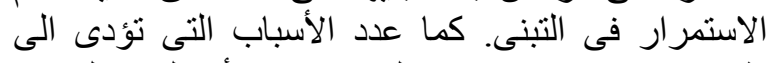

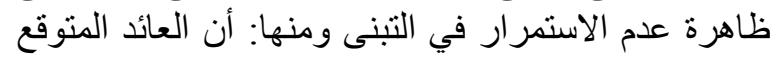




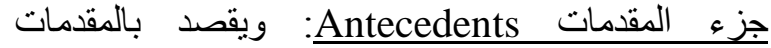
عناصر النسق الاجتماعى الذى يوجد فيه الفيه الفرد، وترجع

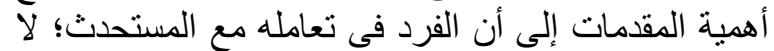

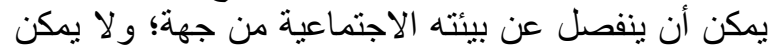

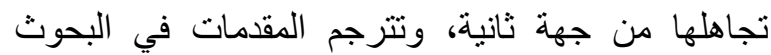

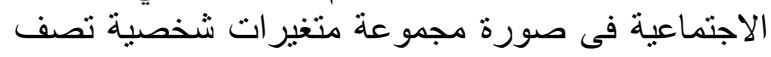

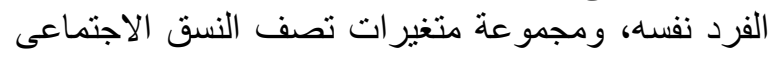
الذى يوجد فيه الفرد.

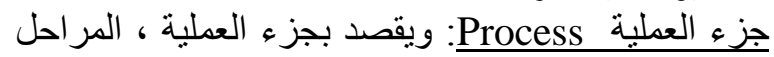

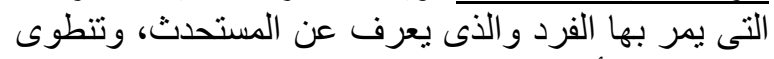

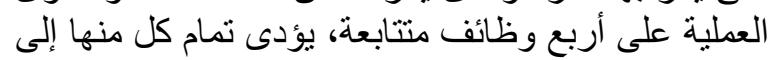
البدء فى الوظيفة التالية وهى: (المعرفة

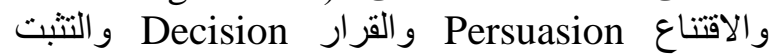

(Confirmation

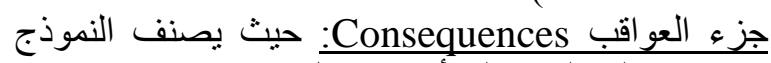

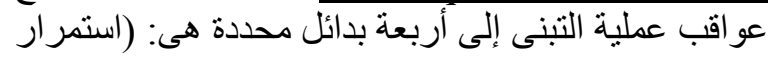

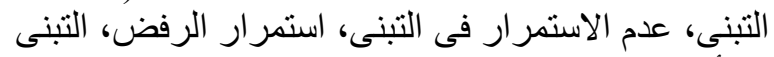

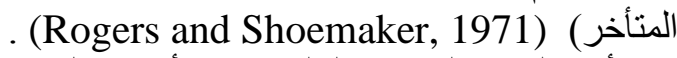

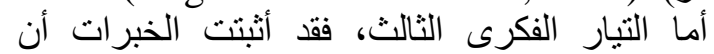

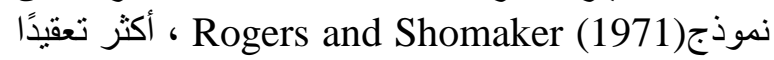
و لا يمكن الاستفادة منه في الدراسة الميدانية بصورة جيدة ،يدة.

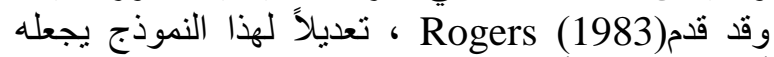

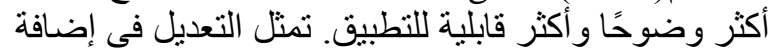

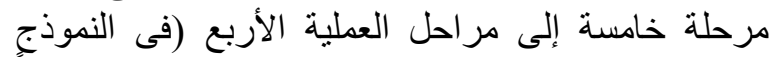

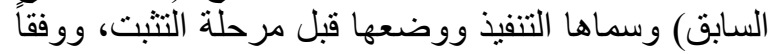

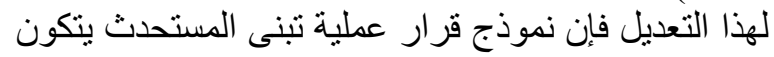
من خمس مراحل متتابعة هى: (المعرفة

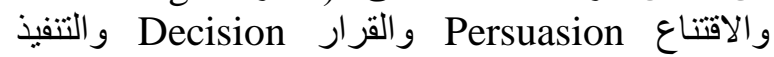
و والتثبت Implementation بالإضافة الى جزء المقدمات والذى تم تعديل أسمه الى جلى

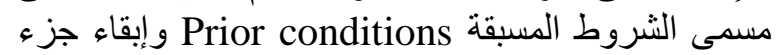
العو اقب Consequences كما هو. ويعقب Rogers)(1983) ، أن الثواهد الامبيريقية

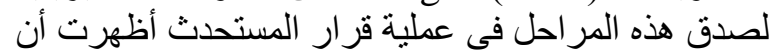

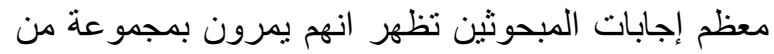

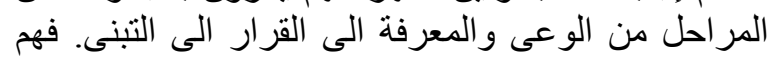

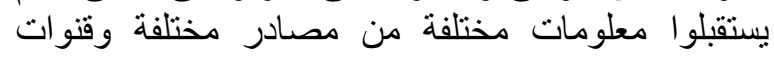

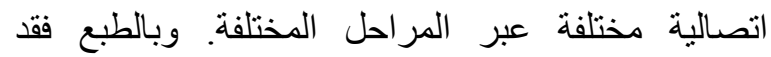
يستخدم الفرد نفس المصدر ونفس القناة الاتصالية ربما بطرق مختلفة فى العديد من المر احل فى عملية اتخاذ قرار الحفار

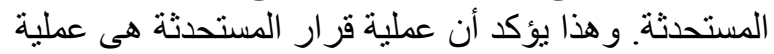

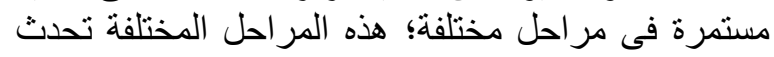

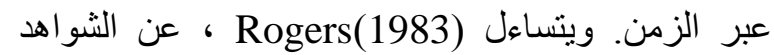

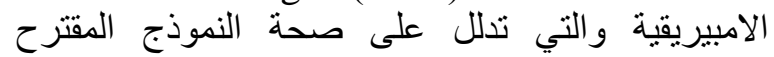

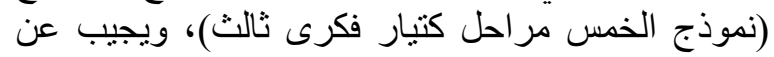

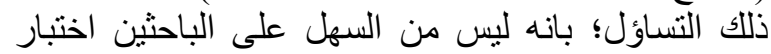

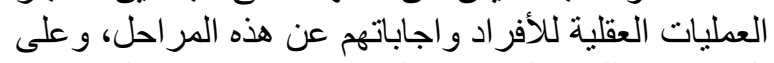

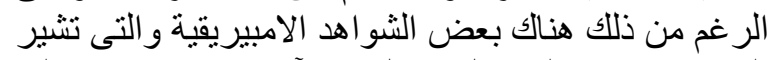

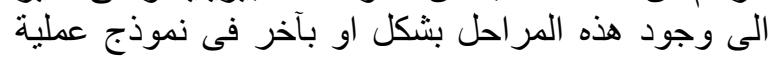

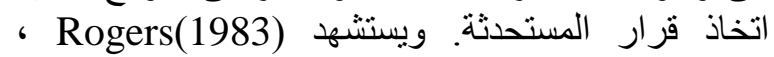

الأول، والذى بدأ عام 1957 عندما قدم عالما الاجتماع الريفى الأمريكيين جورج بيل والأل and Joe Bohlen

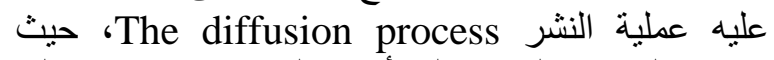
يصور النموذج التبنى على أنه عملية اجتماعية تتم على التى

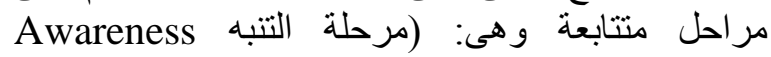
ومرحلة الاهتمام Interest ومرحلة التقييم Evaluation وملنيه

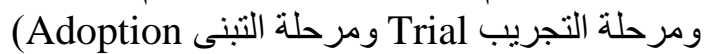

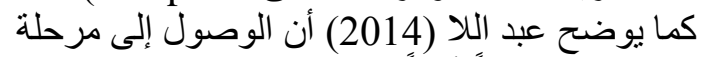

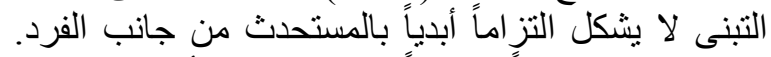

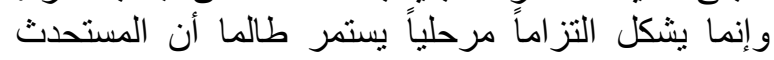

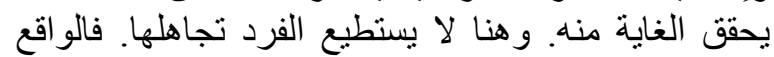

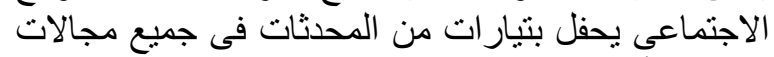
الحياة، الأمر الذى يجعل الفرد ير اجع موقفه باستمر التهار كلما

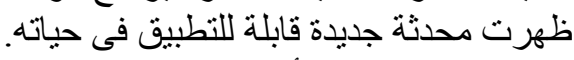

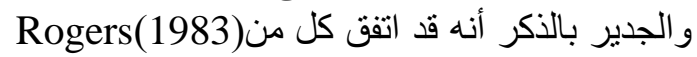

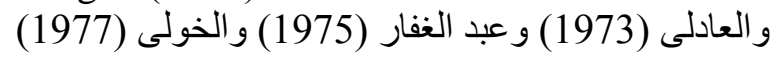
و عبد المقصود (1988) و الطنوبى (1998) مع هذا (1973) التيار الفكرى والذى بصور لمود نموذج التبنى على على أنه عملية

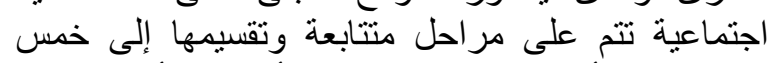

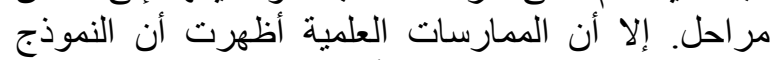

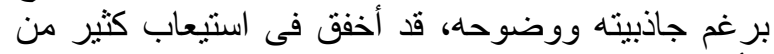

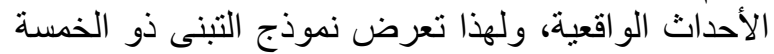

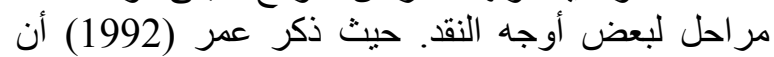

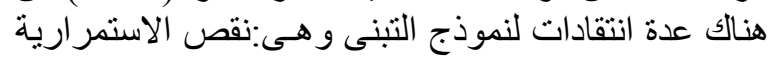

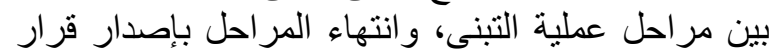

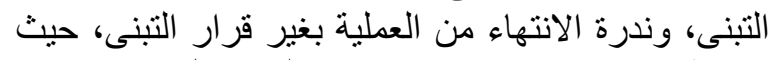

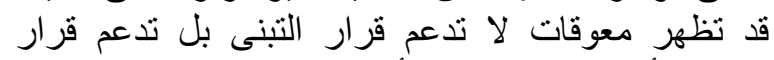

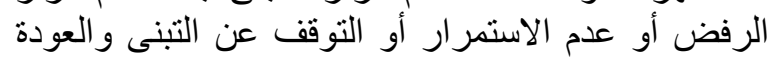
إلى القديم السائد أو التحول إلى فكرة أفضل التصل منها ظهرت

بعدها.

وعلى الرغم من هذه الانتقادات، و التي اظهرتها

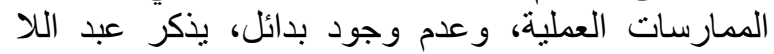

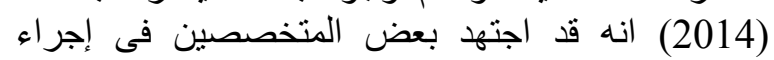

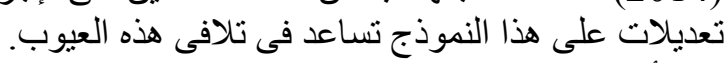

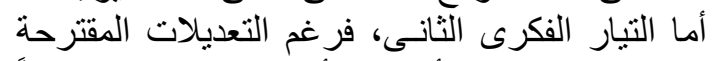

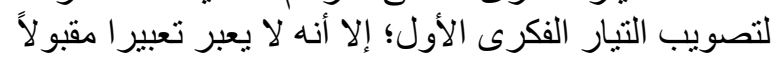

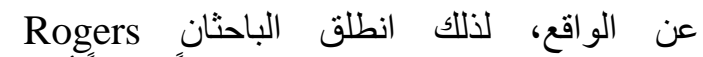
و Shoemaker (1971)، وقدما نموذجاً مختلفاً أطلقا عليه

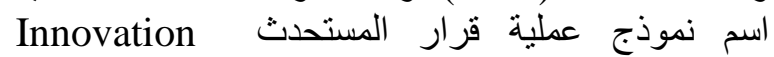
عله decision process

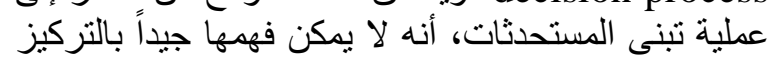

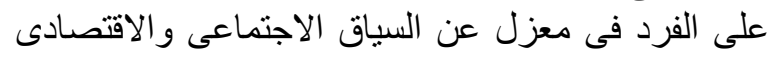

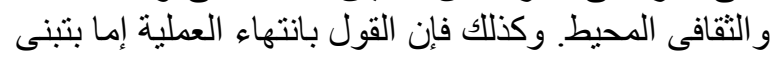

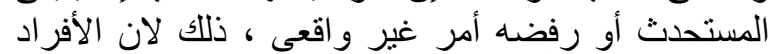

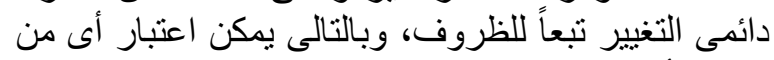

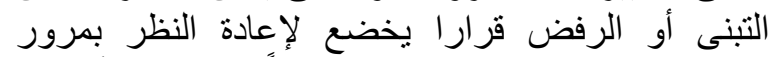

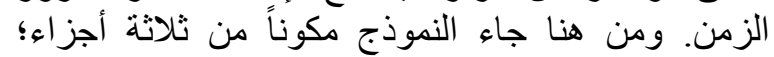
تشكل كل منها حلقة من حلقاء النودن عملية قرار المستحدث وهذه الأجز اء هلى هن: 


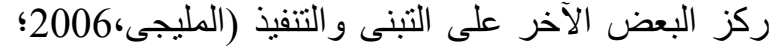

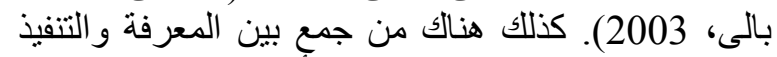

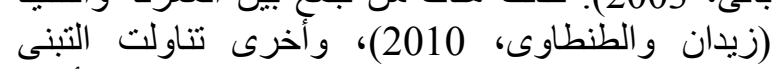
والاستخدام (حمدان، 2005؛ عبد الو هاب، 2003) 2003). و أيضا اليضا

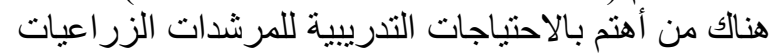

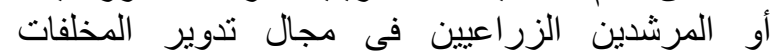

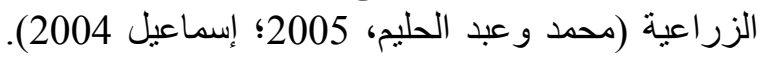
وهناك من تناول ذيوع المستحدثات في مجئ مجال تدوير

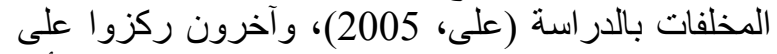

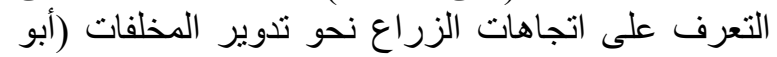

زيد، 2013؛ و هبه ، 1990)

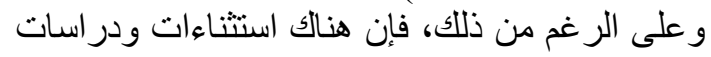

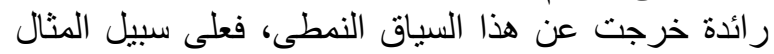

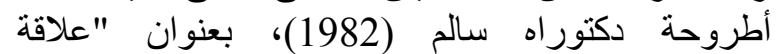
الاتجاهات وقيم المزارعين المصريين برفضئ المض الممارسات

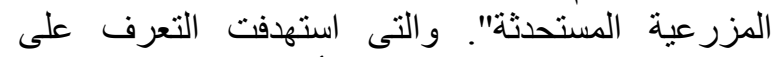

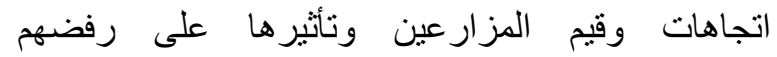

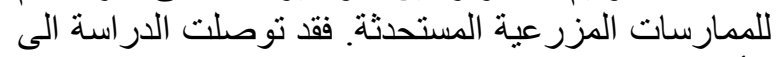

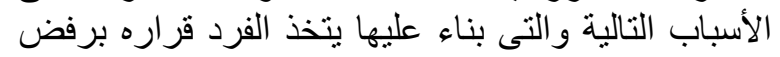

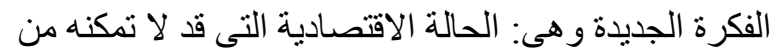

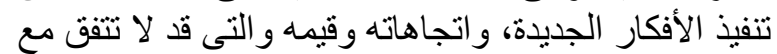

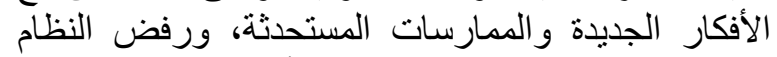
الاجنماعى الذى يعيش فيه لهذه الأفكار، وتعقيد الفكرة الأنية

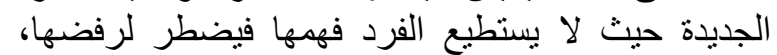

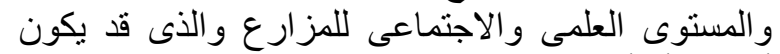
أقل من أو أعلى من الفكرة الجديدة.

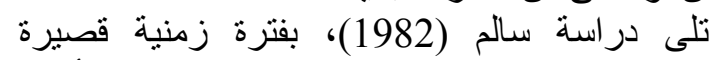

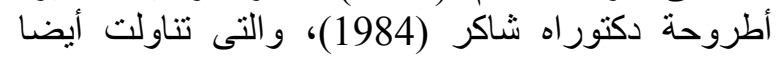

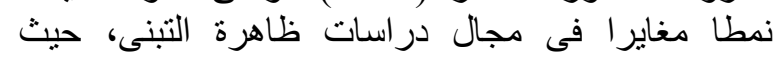

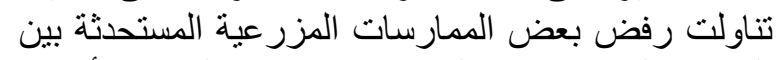

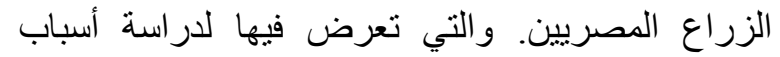

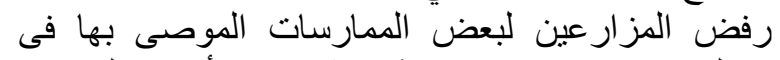

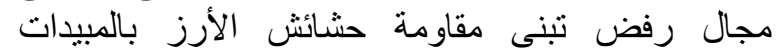

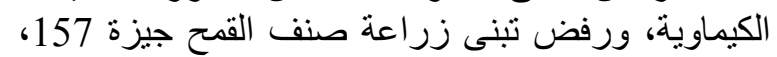

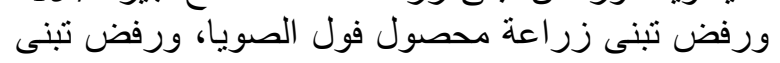

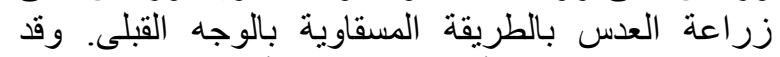

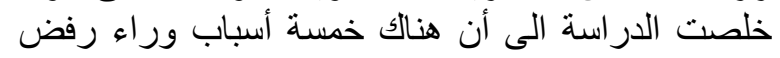

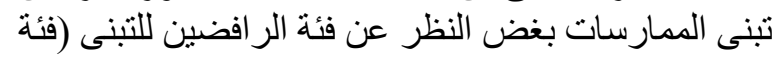

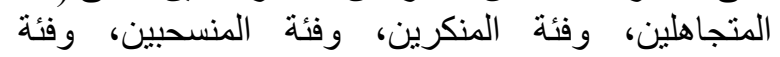

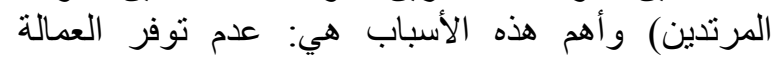

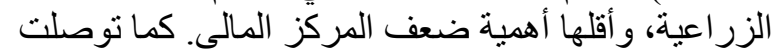

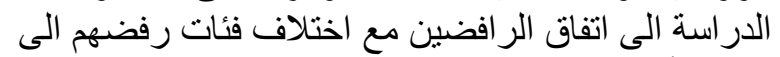

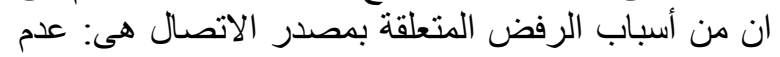

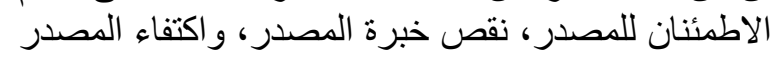

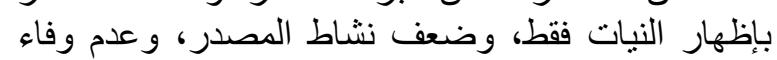

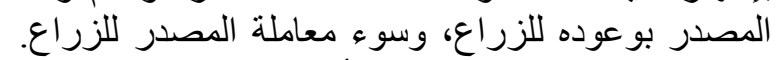

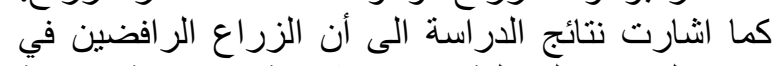

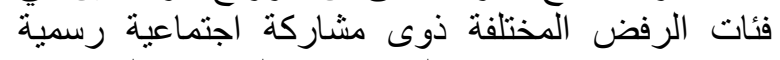

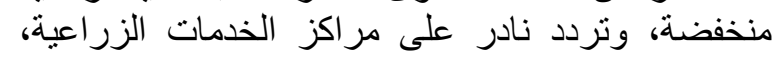

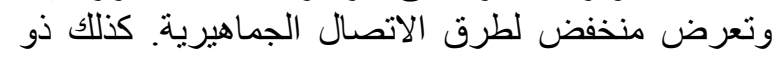

بالعديد من الدراسات والتى تؤيد وجود مراحل نموذج

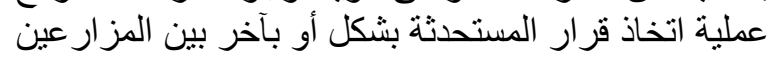

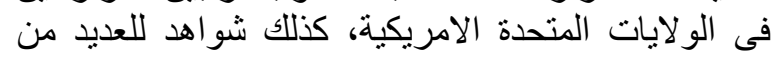
الدر اسات في آسيا.

تشير الثواهد آثيا. بشكل جلى الى وجود مرحلة المعرفة

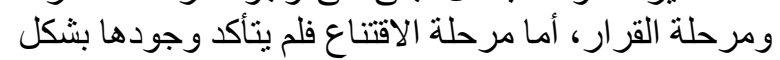

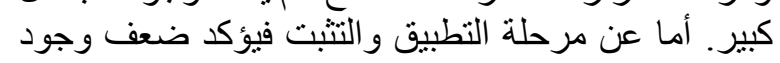

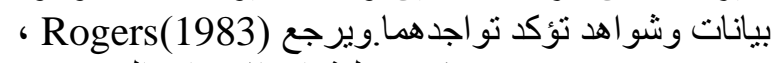

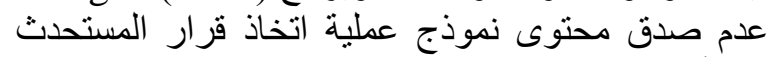

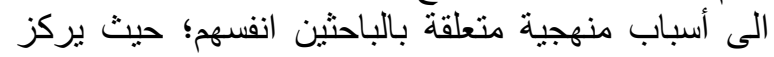

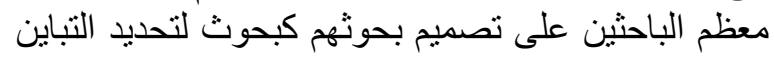

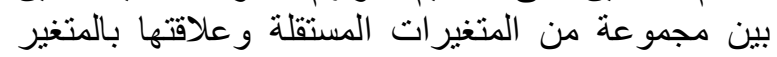

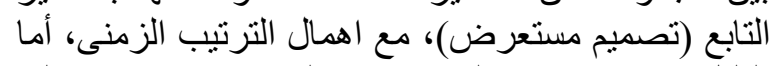

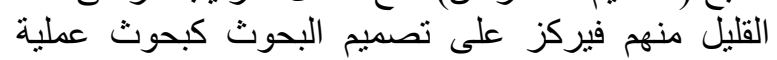

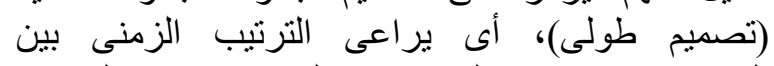

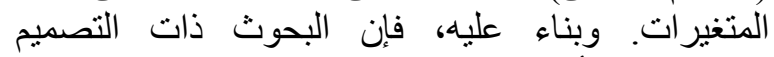
المستعرض ، أى ذو نقطة زمنية واهن واحدة غير كافية وملائمة

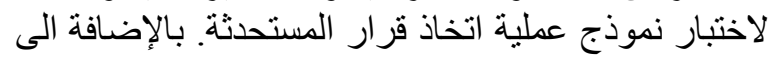

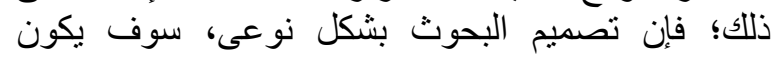

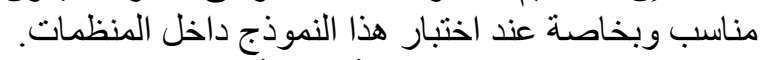

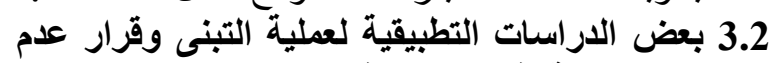

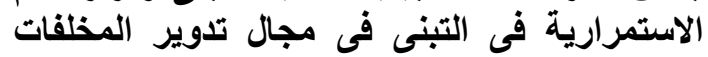

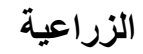

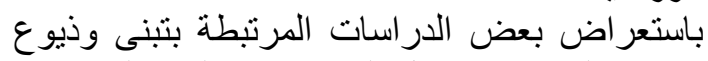

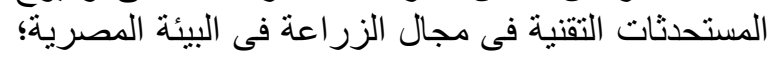

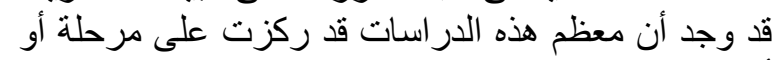

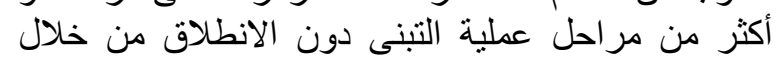

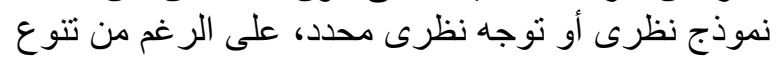

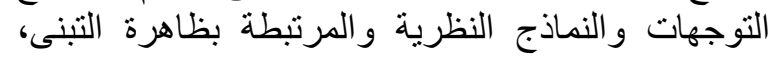
والتى تختلف تبعا للتخصص النظرية الذى ينتمى اليه البهن الباحث.

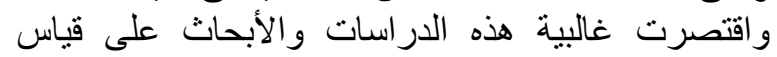

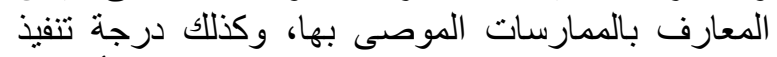

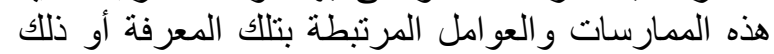

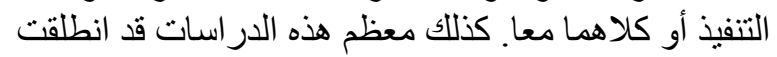

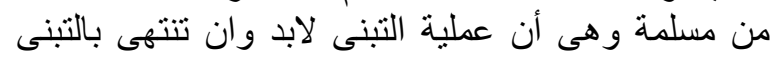

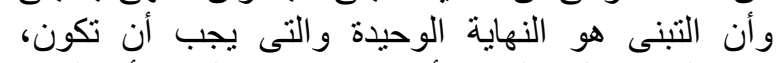

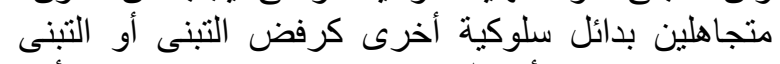

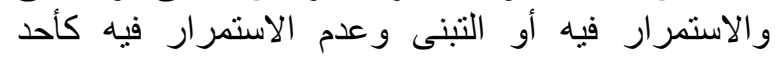

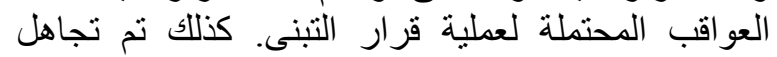

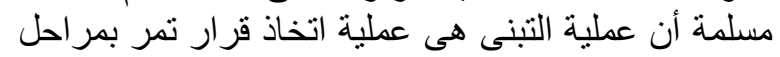

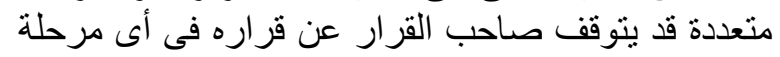

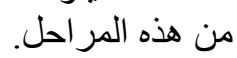

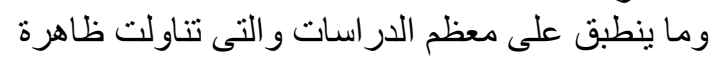

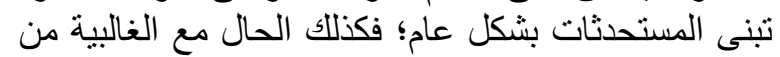

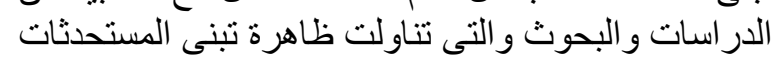

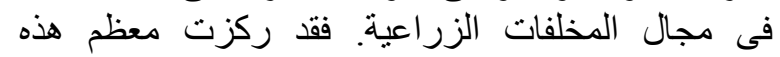

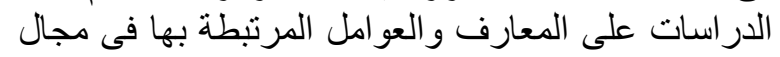

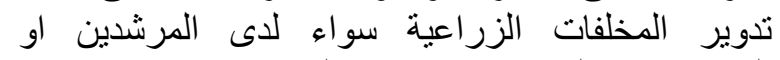

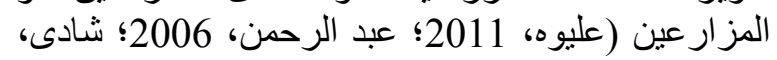
2005؛ شمس، 2003؛ مدكور وميخائيل، 2001)، كما 


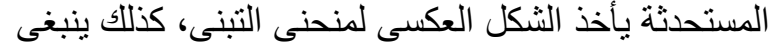

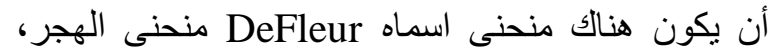

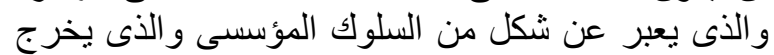
عن النسق الاجتماعى و الثقافى لجماعة أو مجتمع معين.

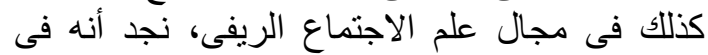

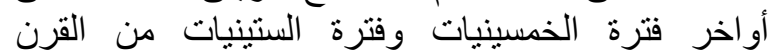

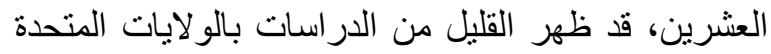

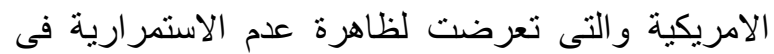

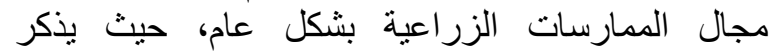
(Bishop and Coughenour(1964) بريف ولاية Kentucky الأمريكية وبعد عشر سنوات

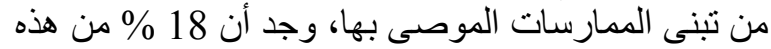

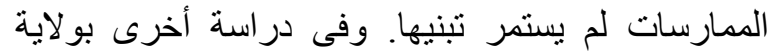

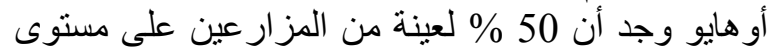

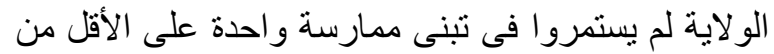

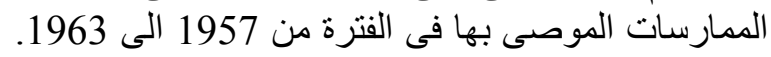

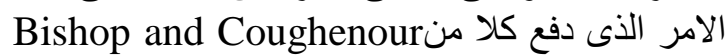
(1964) لدراسة ظاهرة عدم استمرار تبنى الممارسات

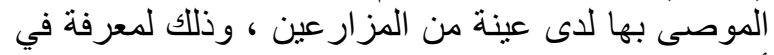
أي مرحلة حدث عدم استمرار في تبنى المثلى المارسات

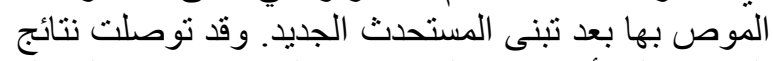

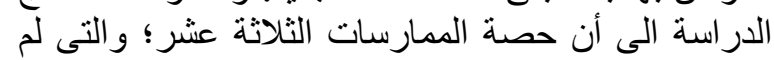
يستمر المز ارعين في تبنيها مقارنة بمعدل التبنى الإجمالى؛

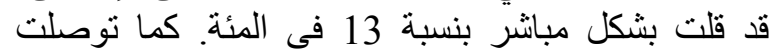

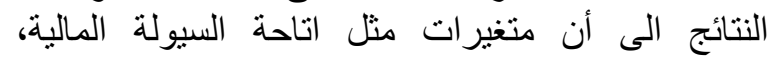

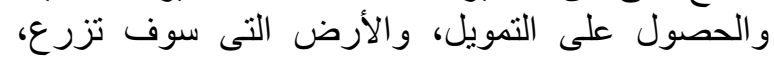

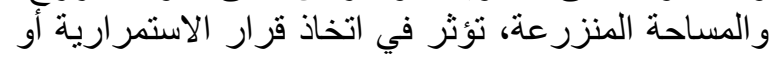

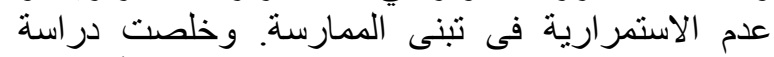
Bishop and Coughenour(1964) مستوى جميع الممارسات الثثلاثة عشر وجميع المزارعين

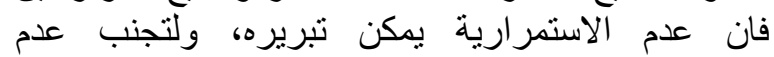

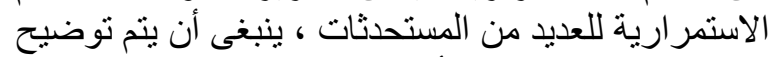

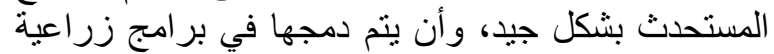

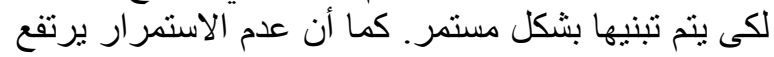

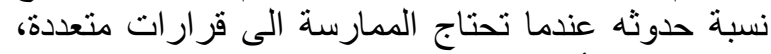

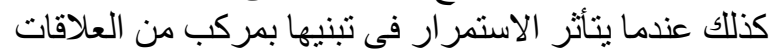

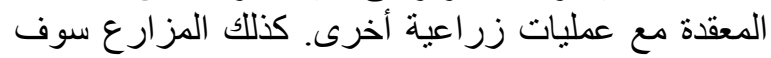

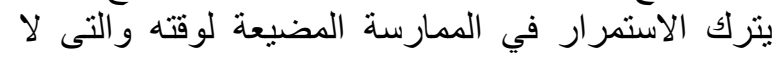

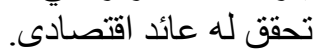

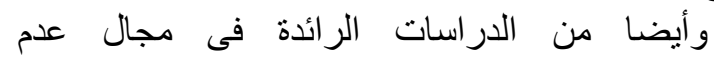

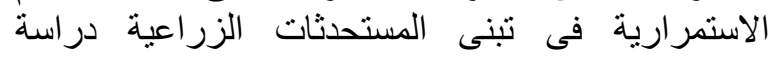

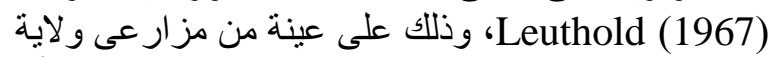

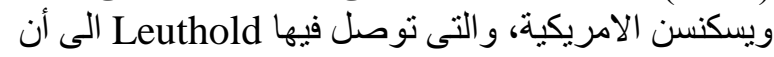

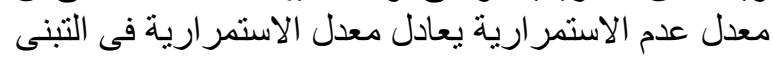
عند أى مستوى من مستويات التبنى وفى التى الى مرحلة زئل زمنية.

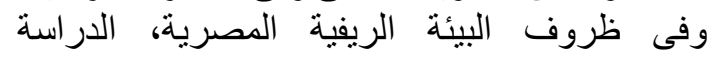

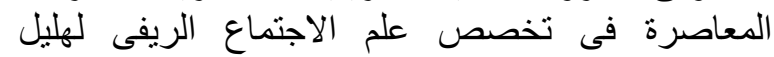

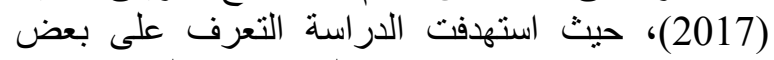

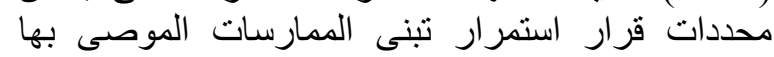
لتدوير بعض المخلفات الزراعية النباتية لأربع معاملات العوصات
قيادية منخفضة، و استبصار وجدانى منوسط، وجمود ذهنى الرئي

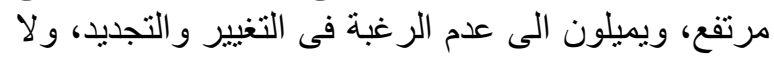

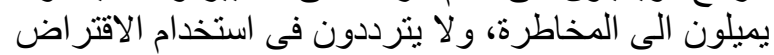

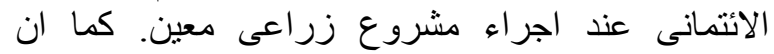
الرافضين بغض النظر عن فئاتهم المختلفة لديهم قيمة فئمة

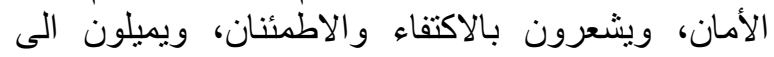

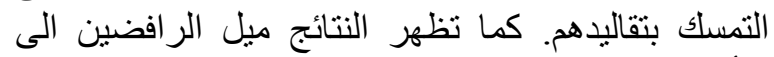

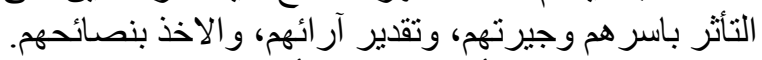

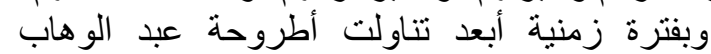

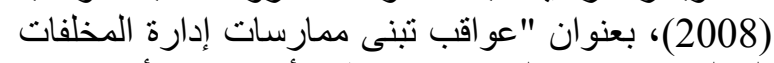

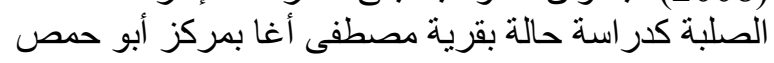

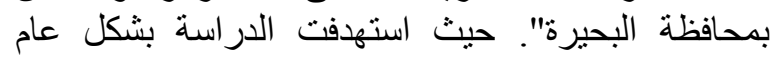
وصف وتحليل العديد من الجوانب المتصلة بعملية تبنى التئي

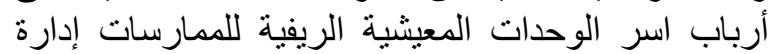

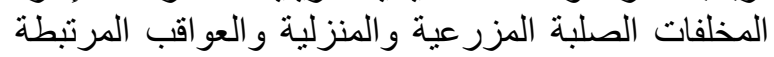

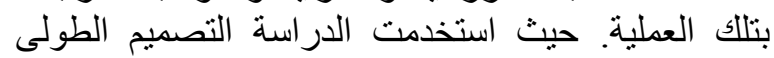

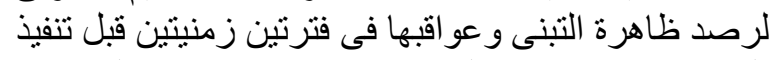

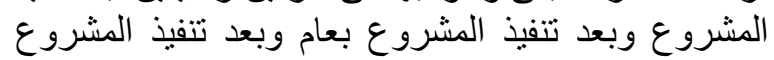

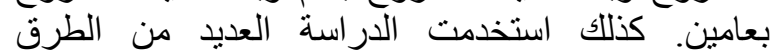

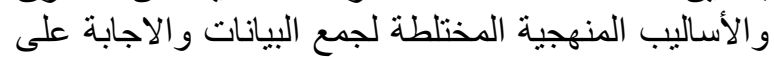

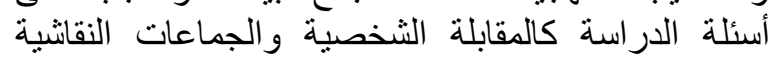

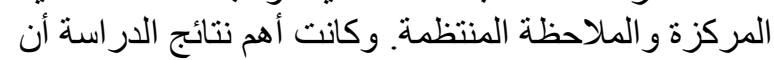

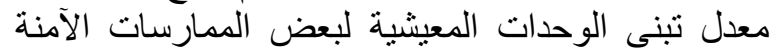

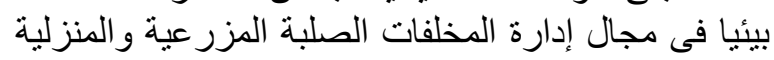

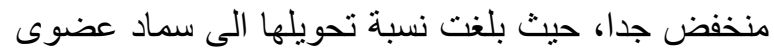

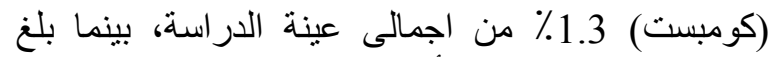

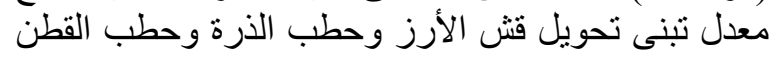

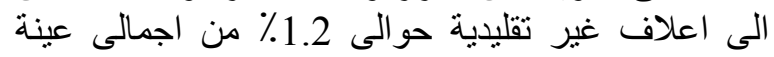

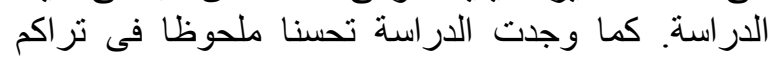
المخلفات الصلبة بالقرية بعد السنة الأولى من التبنى؛ بينى فينما

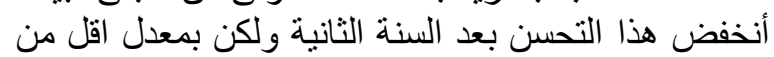

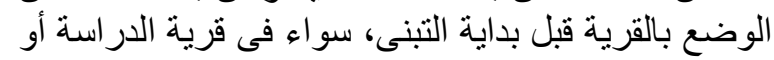

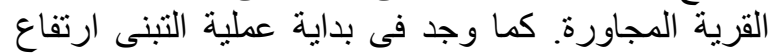

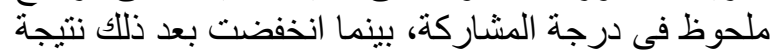

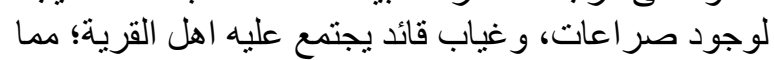

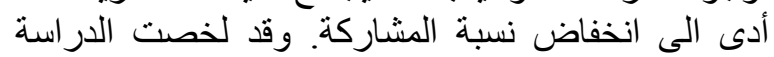

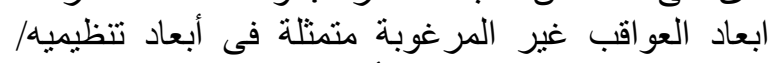
إدارية، و اقتصادية/ تمويلية، وأخر أخرى اجتماعية.

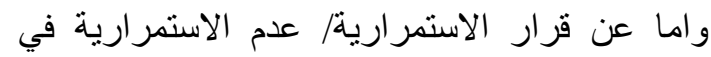

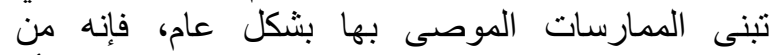

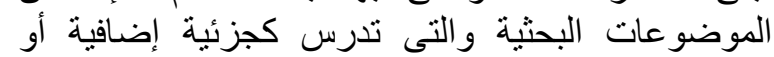

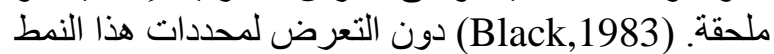
من القرار خلال عملية قرار المستحدثة.

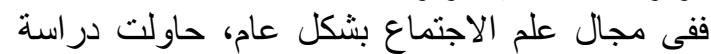

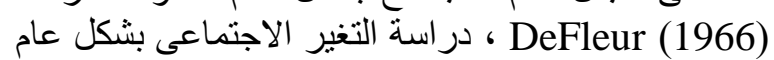

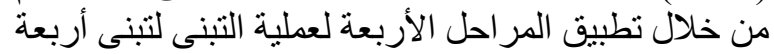

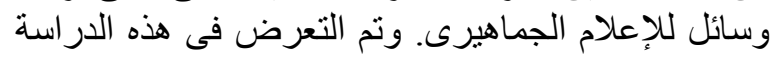

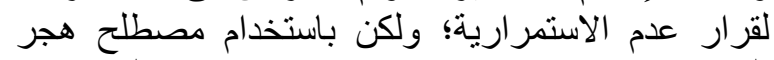

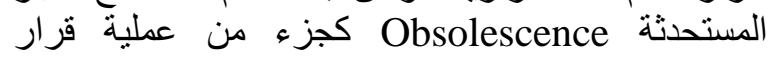
المستحدثة. وتوصلت الدراسة الى أن منحنى هجر 
الثنائى Dichotomous يكون هو المقياس المناسب في وذئ

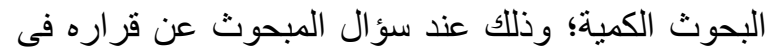

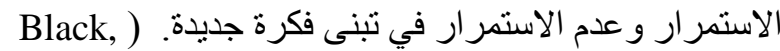

كما حدد العديد من الباحثين الخصائص الثخصية و المرتبطة بمعدل عدم الاستمرارية المرتفع والمنيخ المفضض.

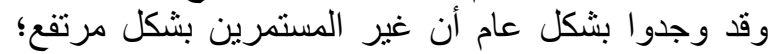

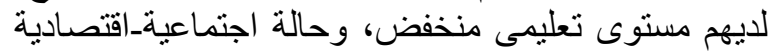
منخفضة، وضعف في الاتصال بوكلاء التغيير.

(Rogers, 1983)

كما لخص(Black (1983) ، مجمو عة من القضايا تم استخلاصها من عملية عدم الاستمر ار فى التبنى بشكل عام الفي

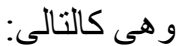

ـالمتبنين ذولى الجئ اتجاه الاستمرارية بصفة عامة لديهم

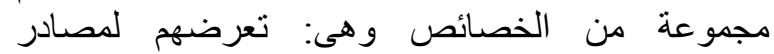

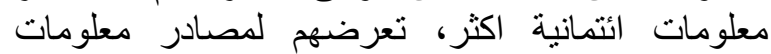

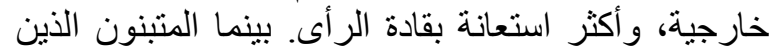

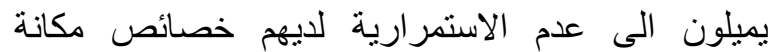

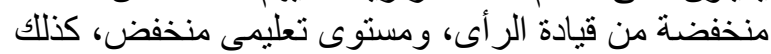
انخفاض التعرض لوسن التيائل الاتصال؛ و هذه النتائج تدعمها العديد من الدر اسة التطبيقية

(Deutschman and Havens 1964; Jorissen 1969;

Leuthold 1965; Leuthold and Wilkening 1965; Leuthold 1967; Silverman and Bailey 1961; Wilkening 1952) ـ المستحدث ذو التسهيلات فى التبنى ذات تأثير ايجابى الإنى

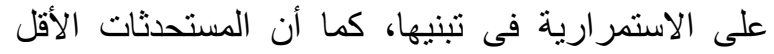

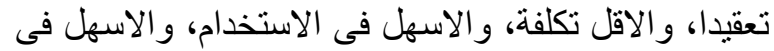
الإجر اءات الإدارية، أكثر جاهزية للتبنى و الاستمر ارية فى الإي

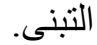
ـ كما أثنارت بعض الدراسات التطبيقية الى أن المعلومات

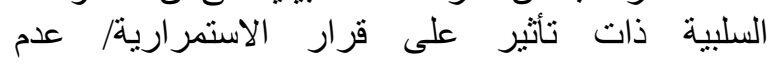

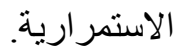

(Johnson and Van Den Ban 1959; Leuthold and Wilkening 1965; Wilkening 1952) المتغيرات ذات التأثير على قرار عملية التبنى ذات أهمية

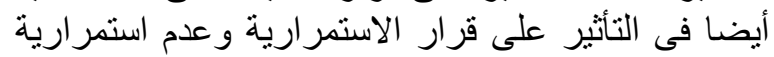

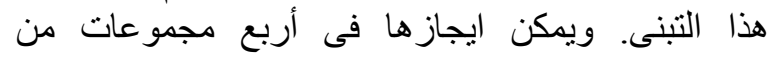

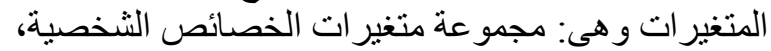

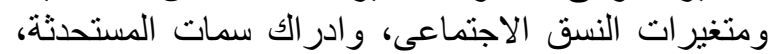

وخبرات الاخرين، واعتبار ات الموقف واعت (Black, 1983).

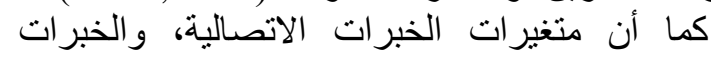

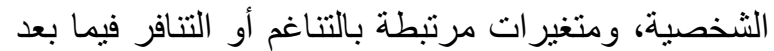

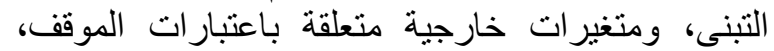

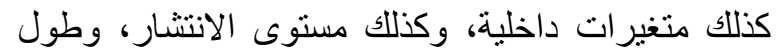

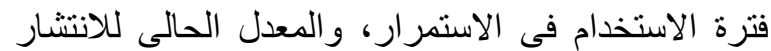

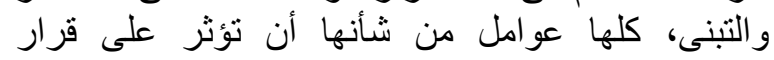
الاستمر ارية و عدم الاستمر ارية (Black, 1983).
و هى: معاملة تبن القمح باليوريا، ومعاملة قش الأرز بغاز

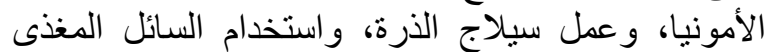

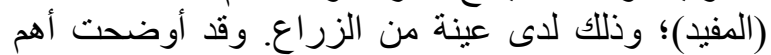

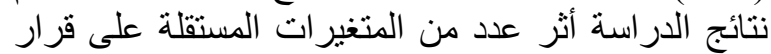

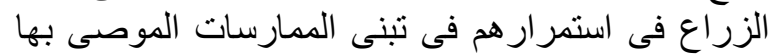

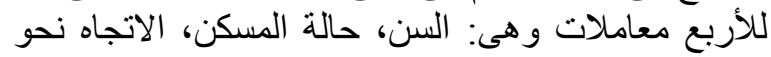

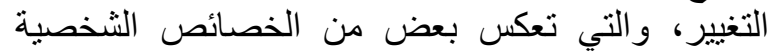

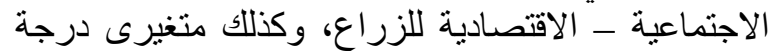

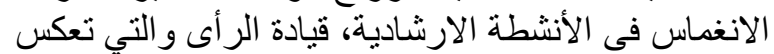

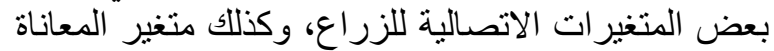

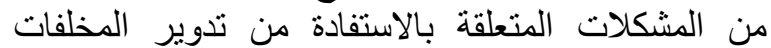

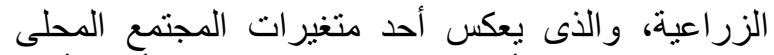

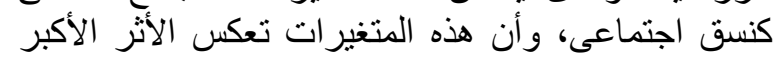

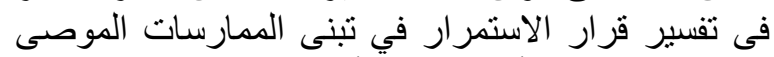

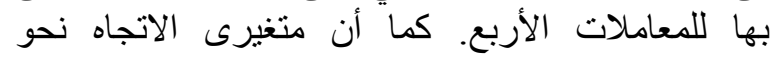

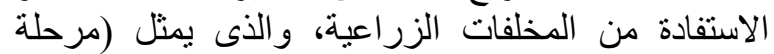
الاقتناع) في نموذج العملية، وكذلك متغير قر الزية ار تبنى وتنفيذ

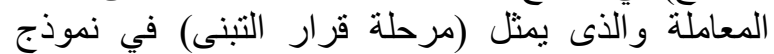

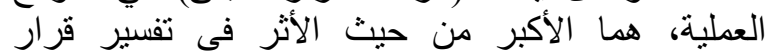

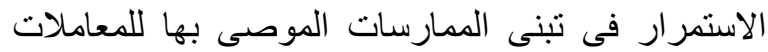

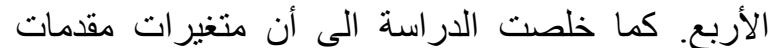

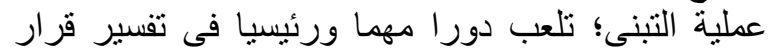

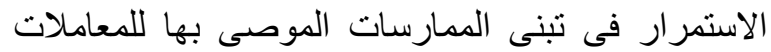

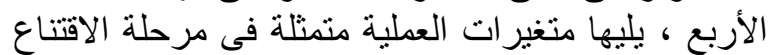

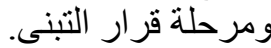

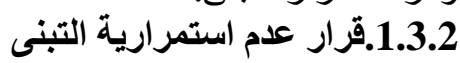

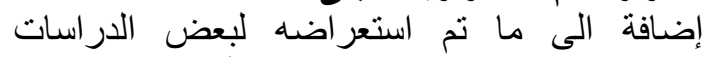

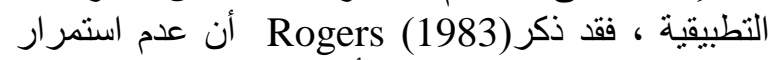

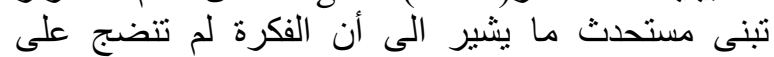

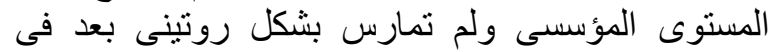
مرحلة التطبيق اثناء عملية قرار المستحدثة. هذا الروتين أقل احتمالا في الحدوث عندما تكون المستحدثة أقل تو افقاه

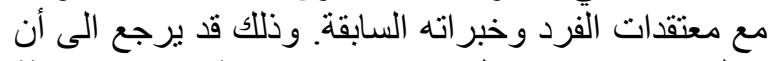

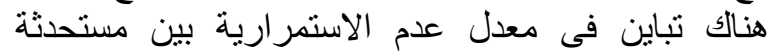

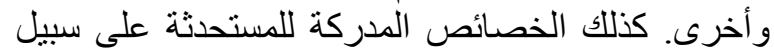

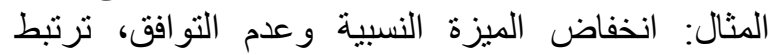

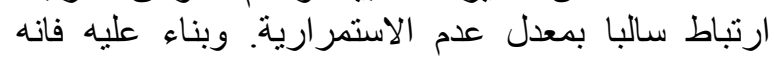
يمكن أن نتوقع أن المستحدثة ذات البثرات الميزة النسبية

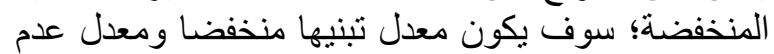

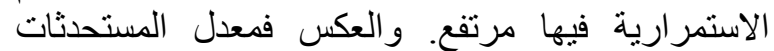

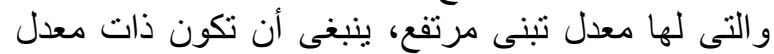
عدم استمر ارية منخفض (Rogers, 1983). هذا ويمكن وصف قرار عدم الاستمرارية كعملية أو أو إن

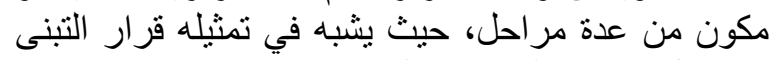

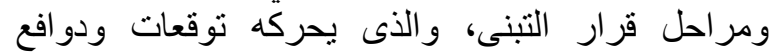

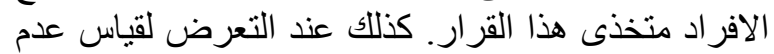
الاستمر ارية/الاستمرارية في التبنى، فان المقياس الأسمى لأسى 


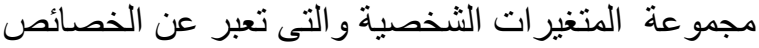

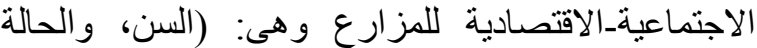

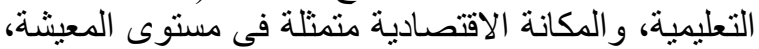
وحيازة الأرض الزراعية، وحيازة الآلات الزية الزية اعية،

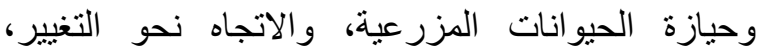

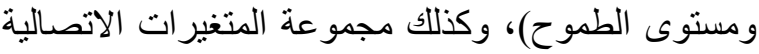

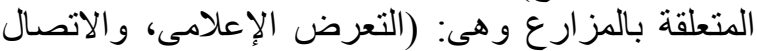

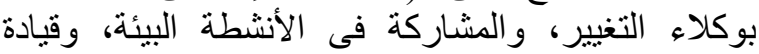

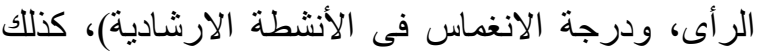

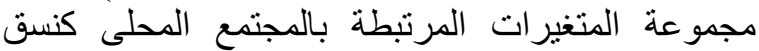

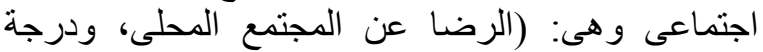

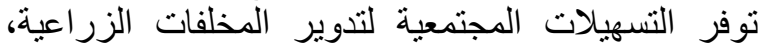
والمعاناة من المشكلات المتعلقة بالاستفادة من تدوير الزير التراتية

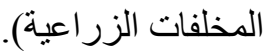

2.4.2 جزء عملية التبنى، ويعبر عن مجمو عة متغيرات

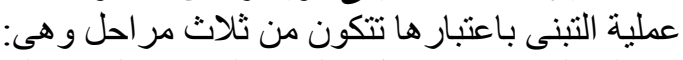

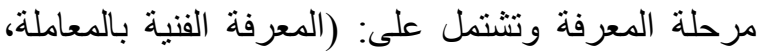
و والمعرفة بالفو ائد الاقتصادية للمعاملة).

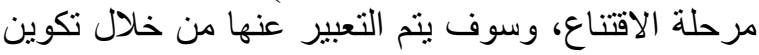
اتجاه نحو الاستفادة من المخلفات الزر التئية

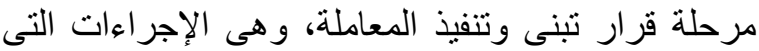
يتبعها المز ارع عار أثناء عملية التنفيذ.

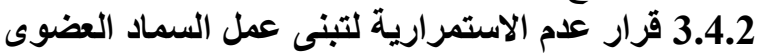

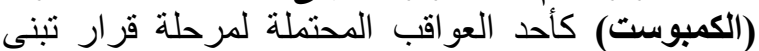

وتنفيذ المعاملة. 3

5.2

لاختبار صحة نموذج احتمالية قرار عدم الاستمر ارية

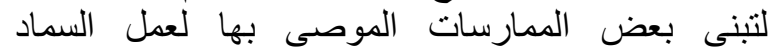
العضوى (الكمبوست)، فسوف يتم اختبار الفروض البعات البحتية التالية؛ وذلك بعد وضعها فى صورتها فئ الصفرية: 1.5.2 الفرض البحثى الأول: توجد علئ علاقة ارتباطية ثنائية بين كل من: (السن، والحالة التعليمية، وحالة الإلة المسكن،

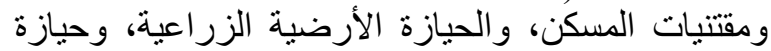

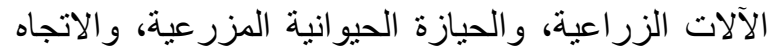

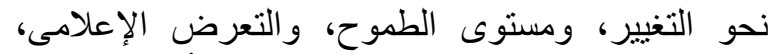
و الاتصال بوكلاء التغيير، و والمشاركة فى الأنشطة البيئية، الإعى،

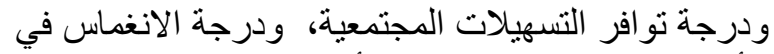

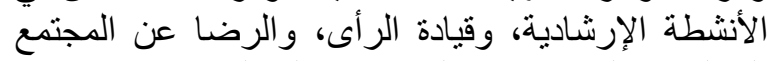

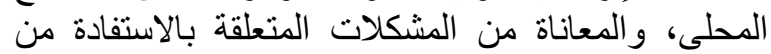
تدوير المخلفات، و المعرفة الفنية بالمعاملة، و المعرفة

$3{ }^{3}$ ينبغى الإشارة هنا الى أن نموذج مراحل عملية اتخاذ القرار حول

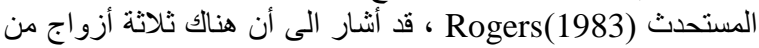

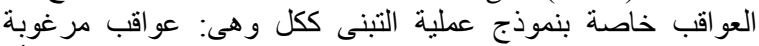

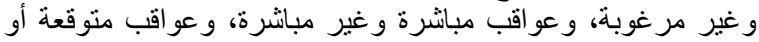

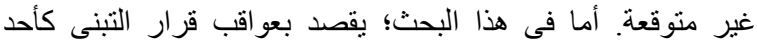

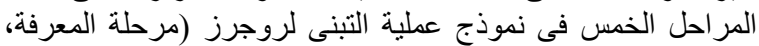
مرحلة الاقتتاع، مرحلة القرار، مرحلة التطبيق، مرحلة التأكيد)،

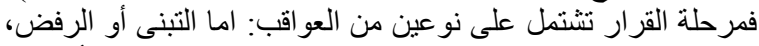

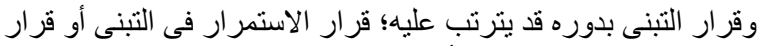

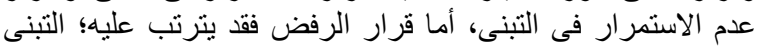
المتأخر أو الاستمر ار فى الرفض. (Rogers, 1983)
4.2. نحو نموذج لقرار عدم استمرارية تبنى وتنفيذ عمل السماد العضوى (الكمبوست)

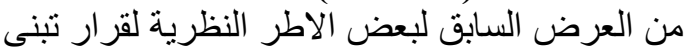

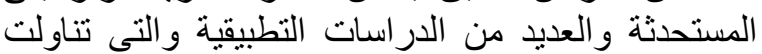

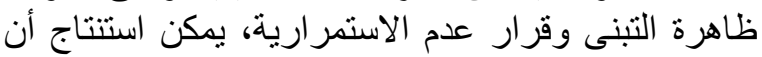

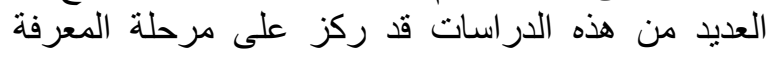

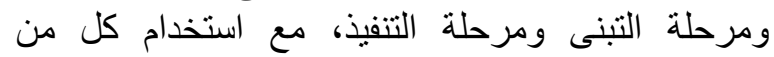
مرحلتى التبنى و التنفيذ بالتبادل من حيث التيث المعنى، و والقليل

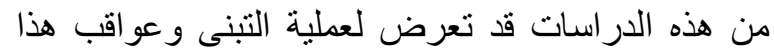

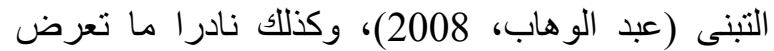

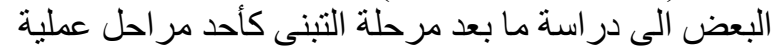

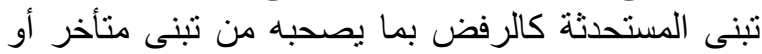
استمرار الرفض شاكر (1984)، أو الاستمرارية وعندم الاستمر ارية فى التبنى.

Bishop and Coughenour(1964), Leuthold1967 ولتحقيق أهداف البحث الحالى ، ونظرا لترات لندرة

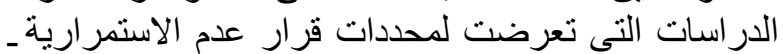

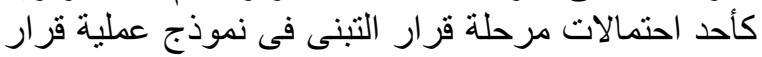

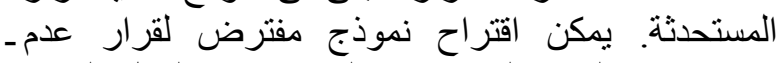

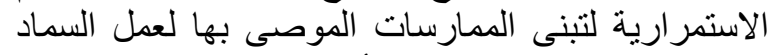

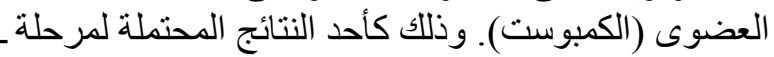
قرار التبنى و التتفيذ فى نموذج عملية قرار المستحدثة.

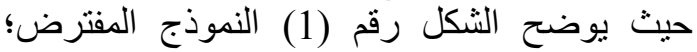
و الذى تم تصميمه بناءً على عدة مسلمات:

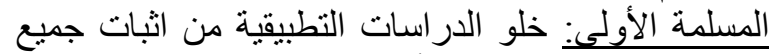

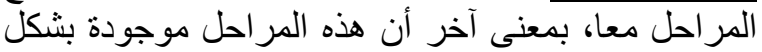

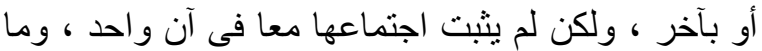
ثبت منها هو مرحلة المعرفة ومرحلة الاقتناع ومرحلة آنس القرار (وقد تشنتمل على قرار التبنى فقط؛ أو قد تثنتمل التهل على التبنى و التنفيذ معا).

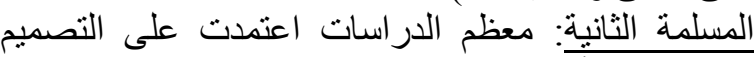
المستعرض أنى جمع البيانات خلال نقطة النقات زمنية واحدة؛ و على الرغم من تفضيل (1983) Rogers ، للتصميمات الفيات

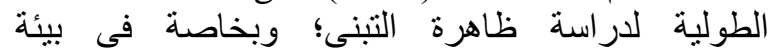
المنظمات؛ الا أن ذلك الامر يصعب تطبيقه عمليا ، لذلك بلك

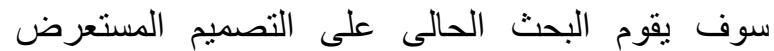
و استخدام التيار المنهجى الكمى. المسلمة الثالثة: معظم الدر اسات قد قامت بقات بقاس متغير اتها

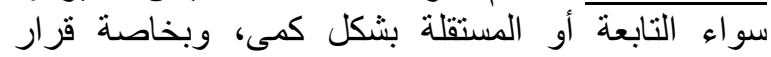

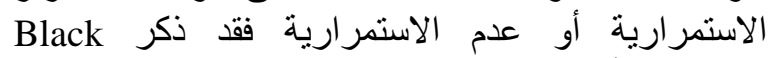

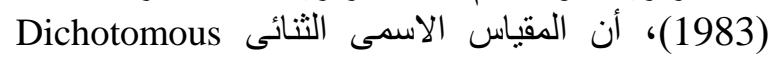

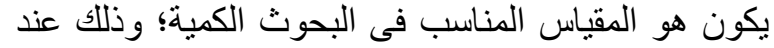

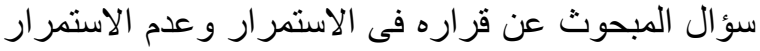

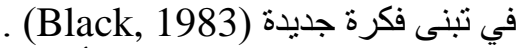
وبناء على هذه المسلمات؛ فيمكن أن يكون النموذج المقترح مكون من ثناثة أجزاء كالتالى التئ

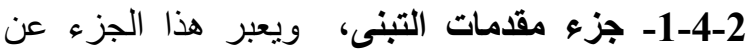

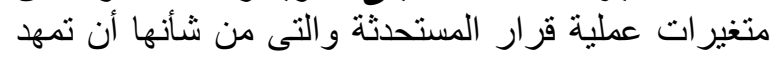
لعملية التبنى والتنفيذ والاستمر ارية أو أو عدم الاستمر ارئية فيها، ويتمثل فى ثلاثة مجموعات من المتغيرات التئن وهى: 
ولتمثيل المجتمع البحثى لمزارعى قرية أريمون

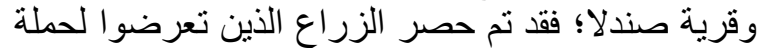

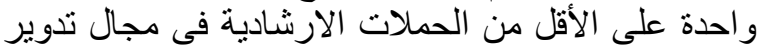

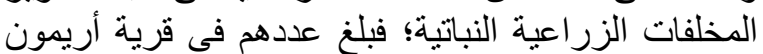

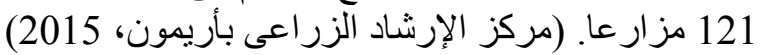

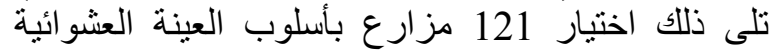

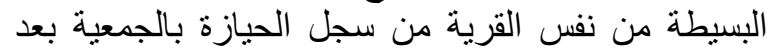

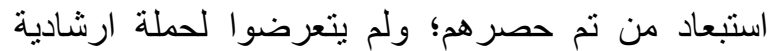

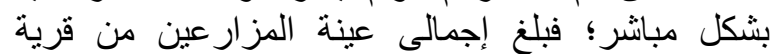

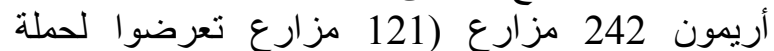

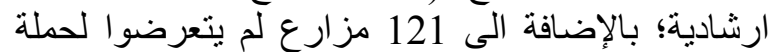

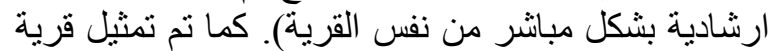
صندلا باختيار 100 مزارع بأسلون بأسلوب العينة العشوائية البسيطة من خلال سجل الحيازة بالجمعية الزراعية؛

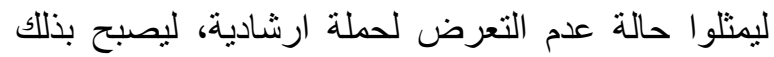
حجم العينة الكلى بكلا القرينين 342 مز ارع كعينة اجمالية لئبح بلية في هذا البحث. 2-3 الاجراءات

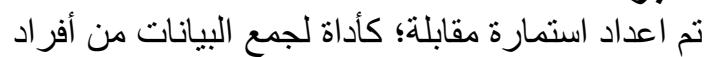
العينة البحثية؛ باستخدام أسلوب المقابلة البيلة الثخصية.

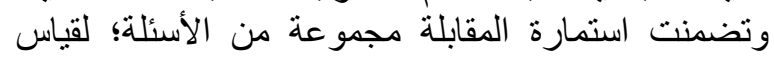

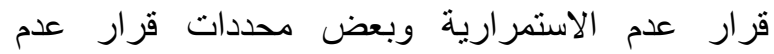

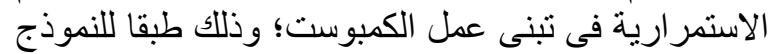

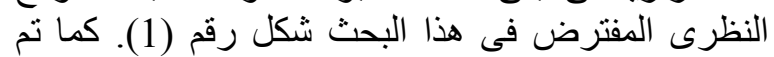

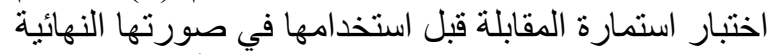

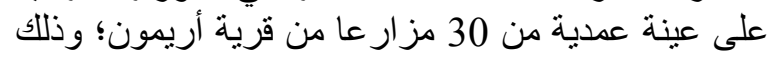
بعد استبعاد أفراد عينة هذا البحثة.

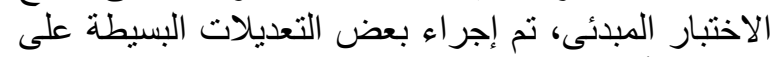

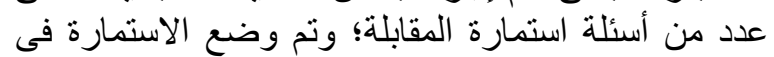
صورتها النهائية. كما تم جمع بيانات هذا البحث في الفترة من بداية شهر مايو 2015م وحتى نهاية شهر أغسطس لفانس 2015م.

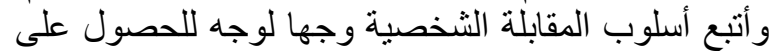

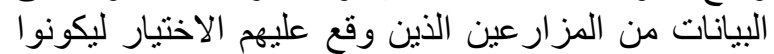

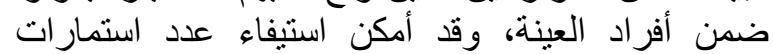

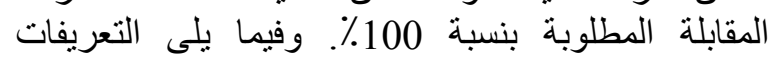

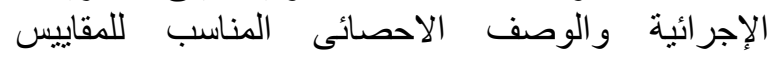

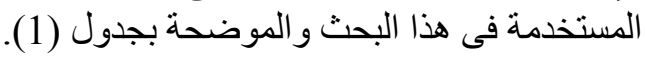
1-2-3 متغيرات المقدمات 1-1-2-3 متغير ات اجتماعية_اتتصادية المفية

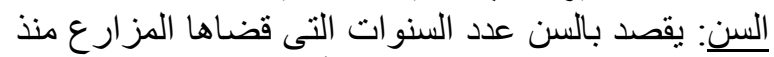
المبلاد وحتى وقت إجر اء البحث لأقرب سنة الته ميلادية.

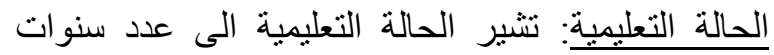

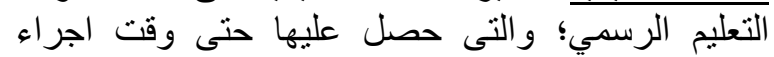

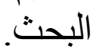

حالة المسكن: يقصد بحالة المسكن كأحد مؤشر ات المكات المكانة

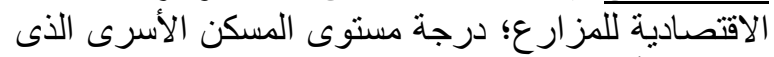

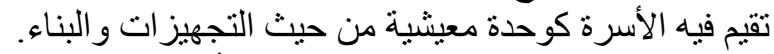
مقتنيات المسكن: يقصد بمقتنيات المسكن كند كأحد مؤشر ات

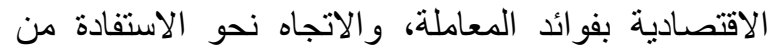

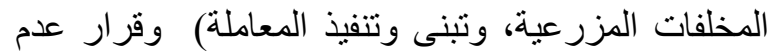

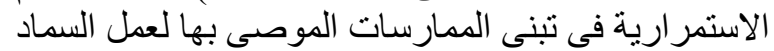

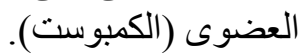
2-5-2 الفرض البحثى الثانى: توجد علاقة ارتباطية بين

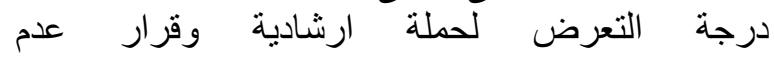

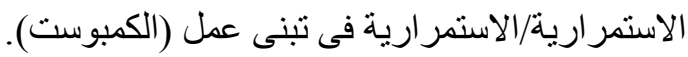

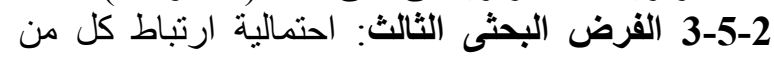

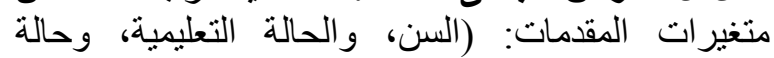

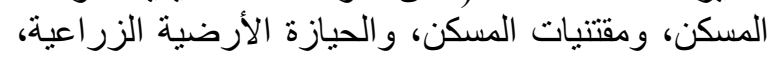
وحيازة الآلات الزراعية، واليكن، والحيازة الحيوانية الأرضية الززرعية، واعية

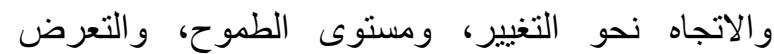

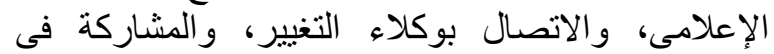

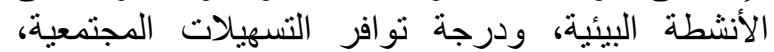

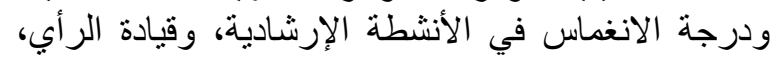

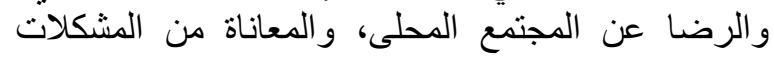

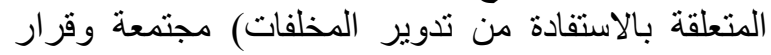

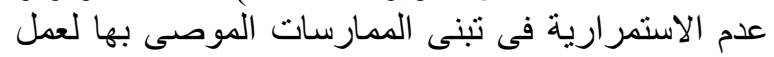
السماد العضوى (الكمبوست).

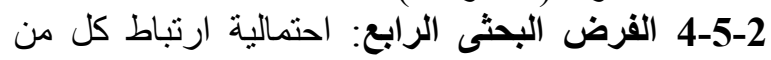

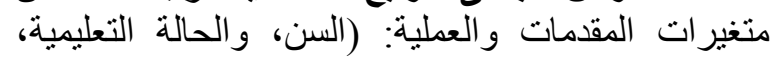

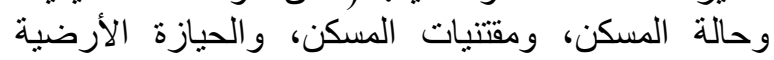
الزراعية، وحيازة الآلات الزراعية، والية، والحيازة الحيوانية الأرضية

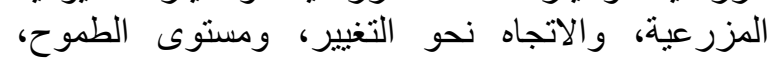

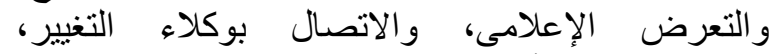

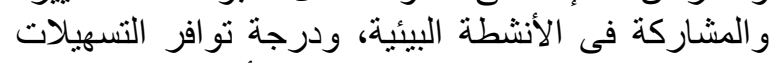

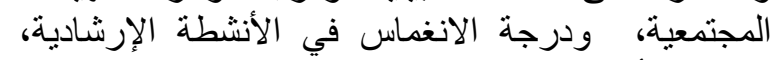

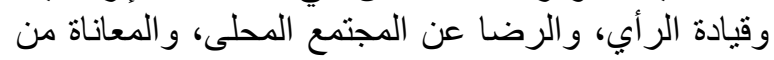

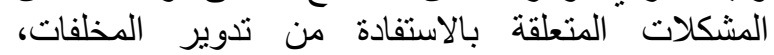

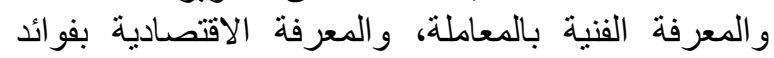

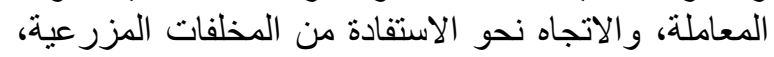

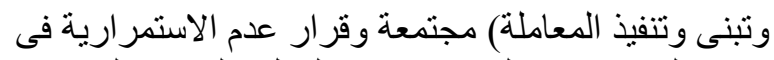

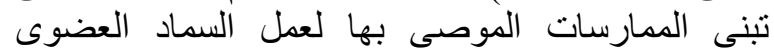

\section{3. الطرق والأساليب البحثية}

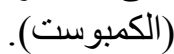

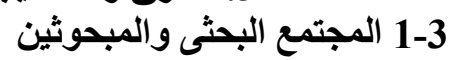

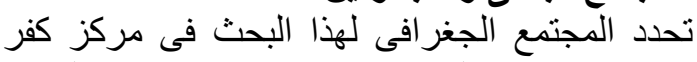

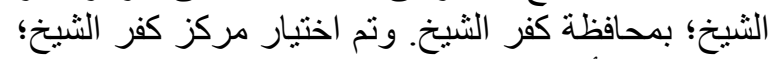

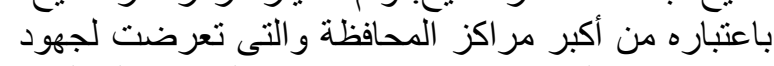

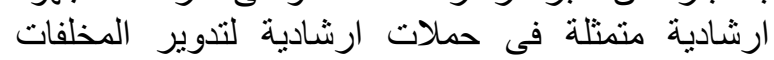

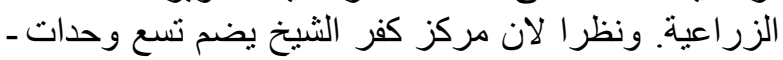

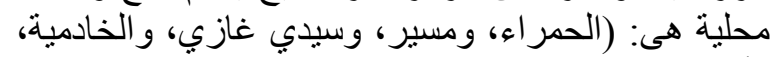

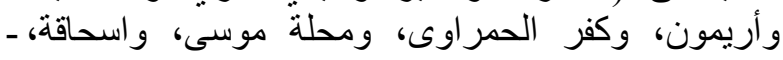

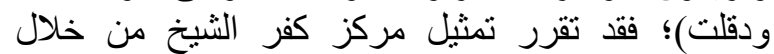

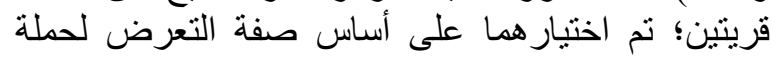

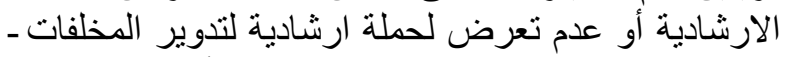

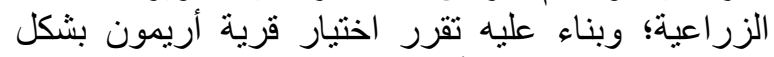

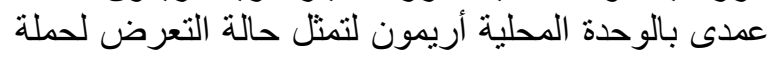

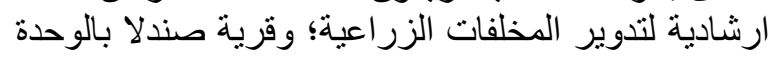
المحلية لتمثل حالة عدم التعرض لحملة ارشادية. 


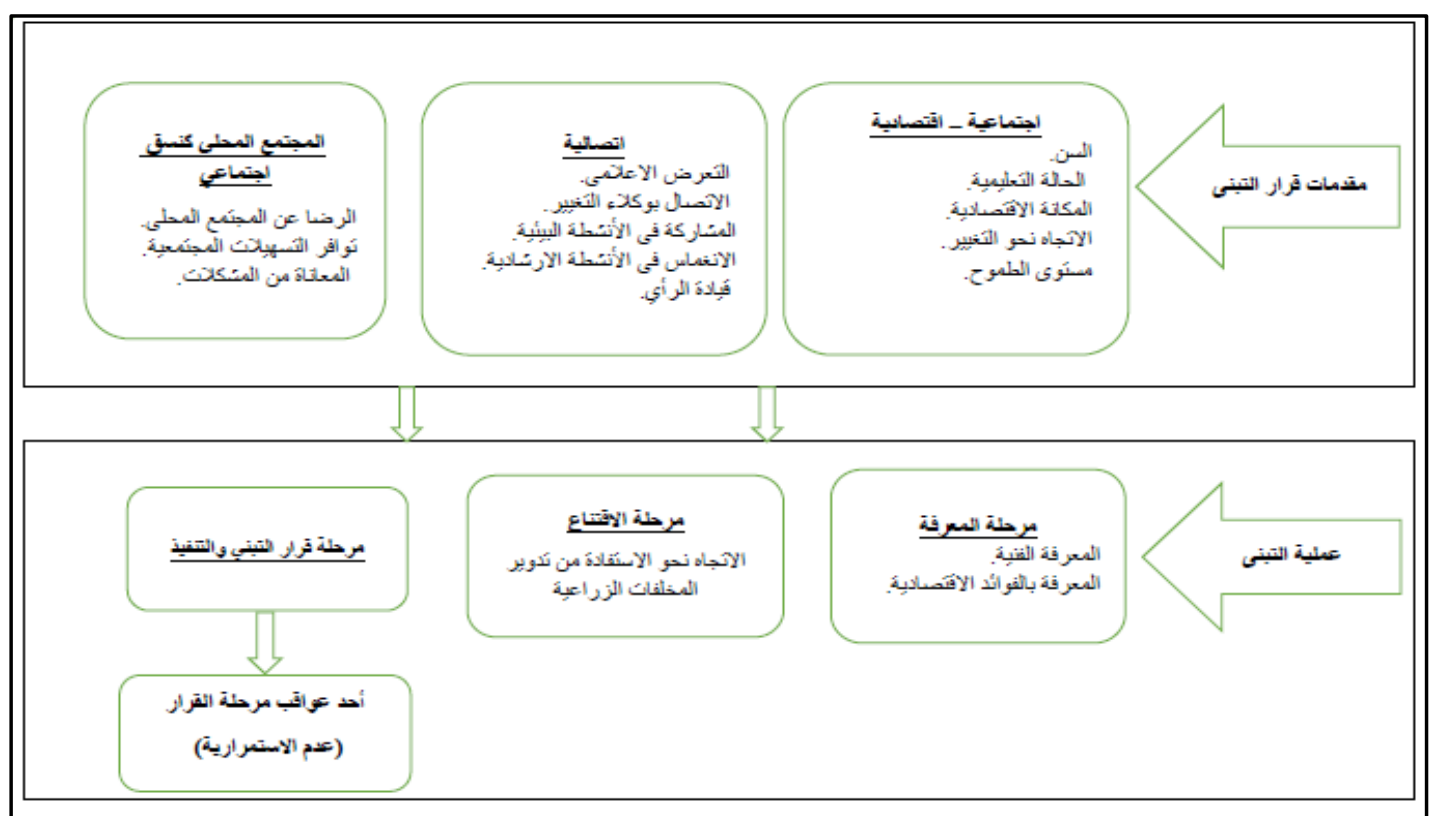

شكل(1): نموذج مفترض لقرار عدم الاستمرارية فى تبنى الممارسات الموصى بها لعمل الكمبوست.

\begin{tabular}{|c|c|c|c|c|}
\hline كعامل ثبات ألفاخ & الالحيارى & الحستوسط & 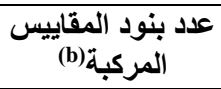 & \multirow[b]{2}{*}{ 1-2-3 مقدمات عملية التبنح } \\
\hline \multirow{2}{*}{\multicolumn{5}{|c|}{ 1-1-2-3 مقتفات عملية التبنية_اقتصادية }} \\
\hline & & & & \\
\hline- & 11.51 & 45.73 & - & 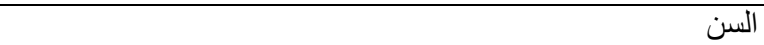 \\
\hline- & 5.63 & 6.18 & - & الحالة التعليمية \\
\hline .632 & 4.33 & 49.12 & 19 & حالة المسكن \\
\hline .851 & 6.65 & 16.42 & 19 & مقتنيات المسكن \\
\hline- & 27.66 & 37.08 & - & الحيازة الأرضية الزر اعية (قير اط) \\
\hline .889 & 7.66 & 6.23 & 12 & حيازة الآلات الزراعية (c) \\
\hline .664 & 2.23 & 3.58 & 10 & حيازة الحيو انات المزر عية (c) \\
\hline .803 & 1.21 & 3.15 & 2 & الاتجاه نحو التغيير \\
\hline .728 & 1.85 & 8.74 & 5 & مستوى الطموح \\
\hline \multicolumn{5}{|r|}{ 2-1-2-3 متغيرات اتصالية } \\
\hline .829 & 3.68 & 3.17 & 5 & التعرض الاعلامى \\
\hline .622 & 9.45 & 4.01 & 3 & الاتصال بوكلاء التغيير \\
\hline .768 & 2.81 & 3.11 & 7 & المشار كة فى الأنشطة البيئية \\
\hline .905 & 4.90 & 3.01 & 6 & درجة الانغماس فى الأنشطة الارشادية \\
\hline .912 & 8.43 & 13.47 & 11 & قيادة الرأى \\
\hline \multicolumn{5}{|r|}{ "3-1-2-3 متغيرات المجتمع المحلى كنسق اجتماعى } \\
\hline .853 & 2.56 & 10.70 & 6 & الرضا عن المجتمع المحلى \\
\hline .622 & 3.25 & 4.54 & 5 & درجة توفر التسيهلات المجتمعية لتدوير المخلفات الزر اعية \\
\hline .757 & 4.82 & 10.22 & 6 & المعاناة من المشكلات المتعلقة بالاستفادة من تدوير المخلفات الزر اعية \\
\hline \multirow{2}{*}{\multicolumn{5}{|c|}{ 1-2-2-3 مرحلة التبنى المعقة }} \\
\hline & & & & \\
\hline .983 & 4.92 & 4.10 & 11 & المعرفة الفنية بالمعاملة (a) \\
\hline .813 & 1.25 & 1.21 & 3 & المعرفة الاقتصادية بفو ائد المعاملة (a) \\
\hline \multicolumn{5}{|r|}{ 2 2-2-2-3 مرحلة الاقتناع } \\
\hline .730 & 2.79 & 2.47 & 6 & الاتجاه نحو الاستفادة من المخلفات الزر اعية \\
\hline \multicolumn{5}{|r|}{ 3-2-2-3 مرحلة قرار التبنى والتنفيذ } \\
\hline .988 & 4.99 & 3.95 & 11 & تبنى وتنفيذ المعاملة \\
\hline
\end{tabular}

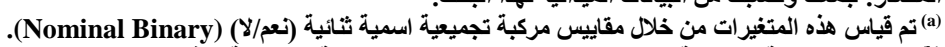

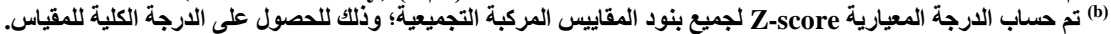

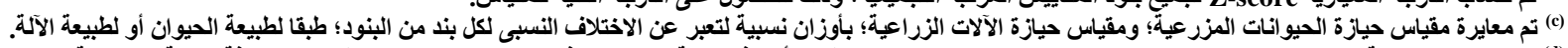

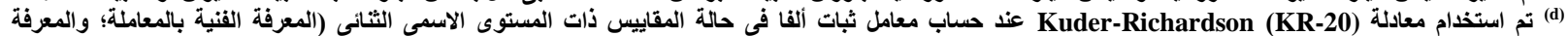


3.1.2.3 متغيرات المجتمع المحلى كنسق اجتماعى المئى

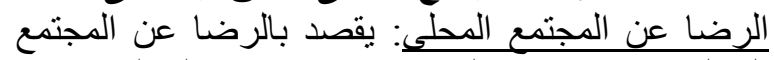

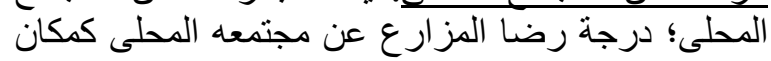

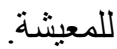

تو افر التسهيلات المجتمعية لتدوير المخلفات الزراعية:

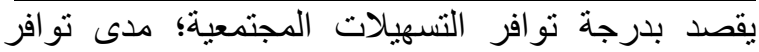

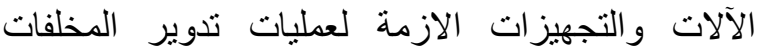

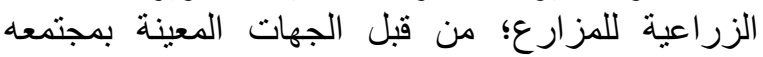

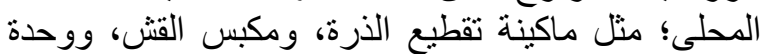

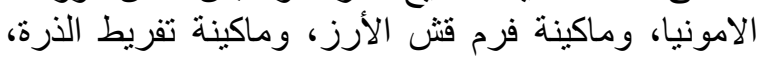

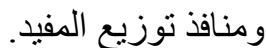

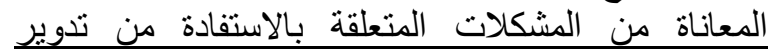
المخلفات الزراعية: تشير المعاناة من المشكلات المئلة المتعلقة

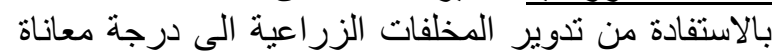

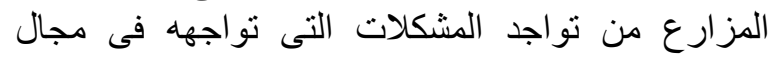

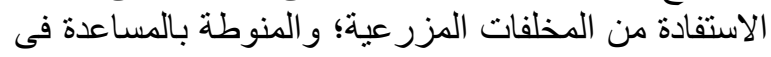

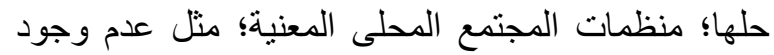

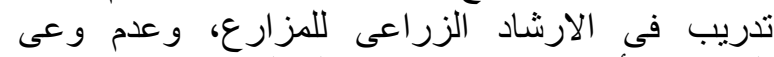

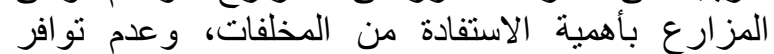

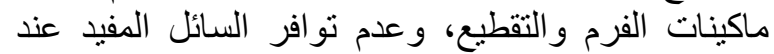

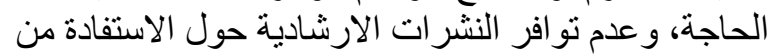

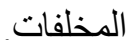

2.2.3 متفيرات عملية التبنى (مرحلة المعرفة؛ مرحلة الاقتناع؛ مرحلة التبنى والتنفيذ) التينى (مرحلة

1.2.2.3 مرحلة المعرفة المئة المينة

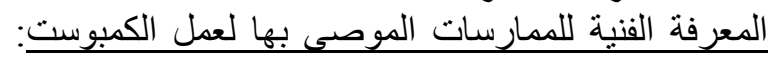

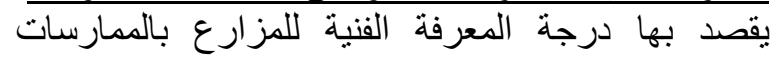

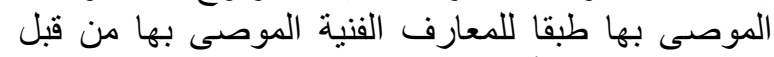

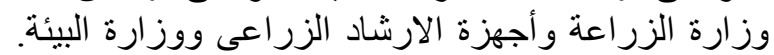

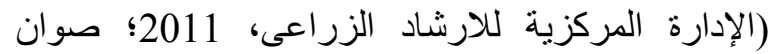
وآخرون، 2010)

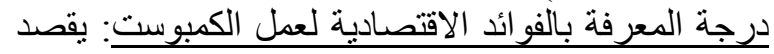

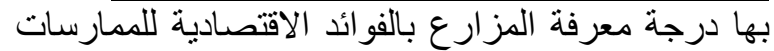

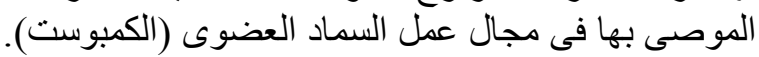

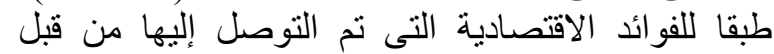

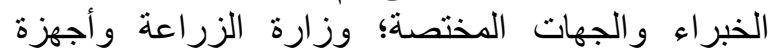

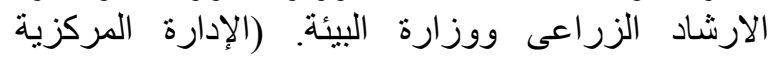

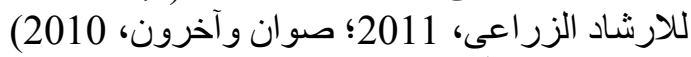

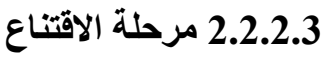
الاتجاه نحو الاستفادة من المخلفات الزراعية (الاقتناع):

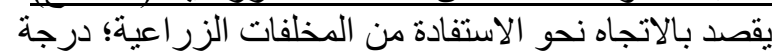

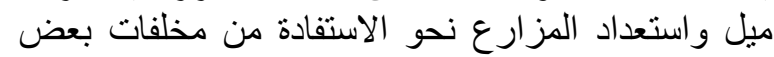

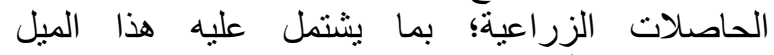

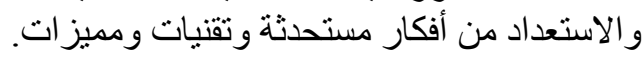
3.2.2.3 مرحلة التبنى والتنفيذ التئي تبنى وتنفيذ الممارسات الموصى بهئي بها لعمل الكمبوست:

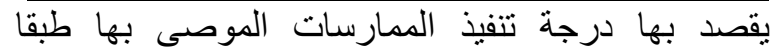

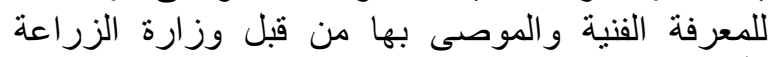
وأجزة الارشاد ووزارة البيئة وذلك بعد اتخاذ المزارع الزراعة
المكانة الاقتصادية للمز ارع؛ عدد الأجزةة المنزلية والتى تمتلكها الاسرة كوحدة معيشية. الحيازة الأرضية الزراعية الأسرية: يقصد بلاعية بالحيازة الأرضية الزراعية الاسرية كأحد مؤشرات الرية الركانة الاقتصادية؛ إجمالى مساحة الأرض الزراعة الزراعية التى يقوم -

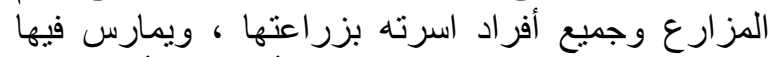

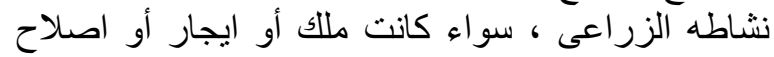

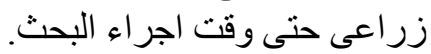

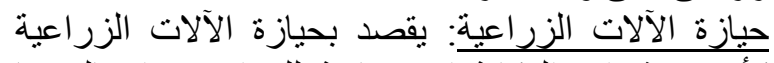

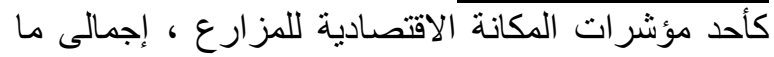
يحوزه ويمتلكه المز ارع من آلات زراعة اللية وقت اجراء إجراء هذا

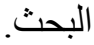
حيازة الحيوانات المزرعية: يقصد بحيازة الحيوانات

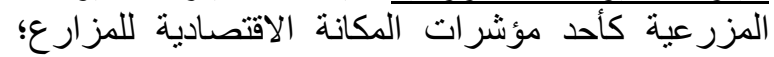

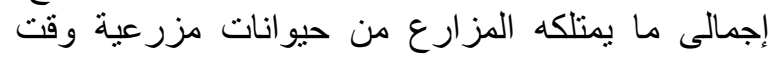
اجر اء هذا البحث.

الاتجاه نحو التغيير: يقصد بالاتجاه نحو التغيير مدى رغبة

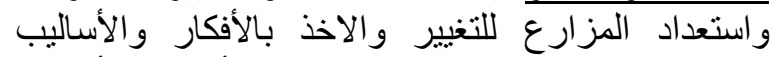
المستحدثة؛ ومدى استعداده لتبنى تللك الأفكار والأساليب

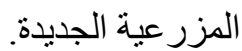

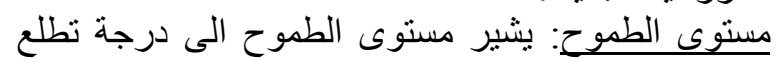

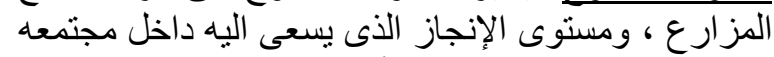

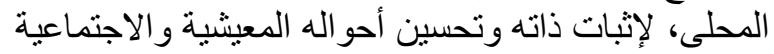

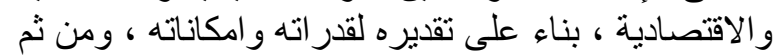

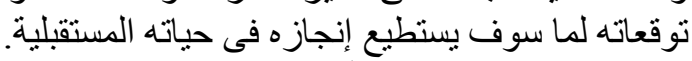

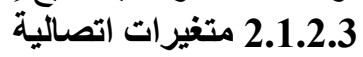

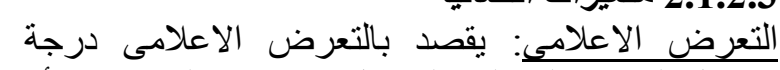

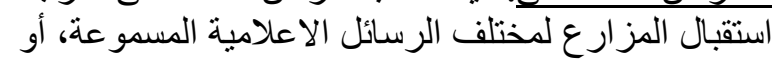

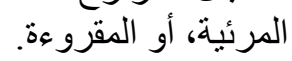

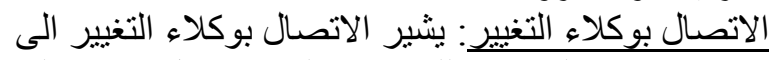

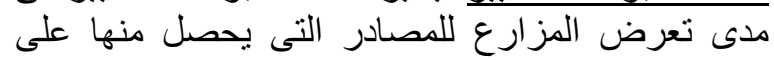

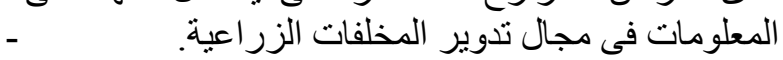

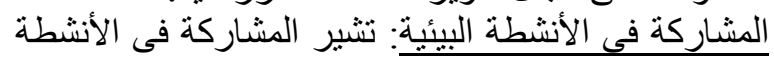

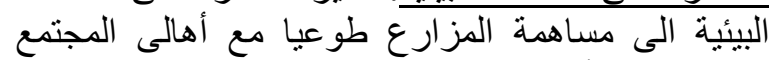

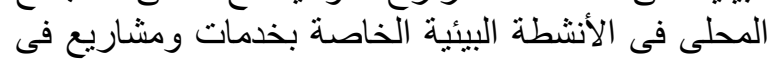

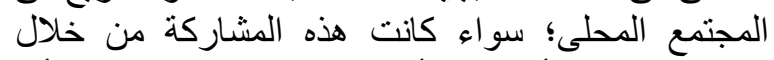

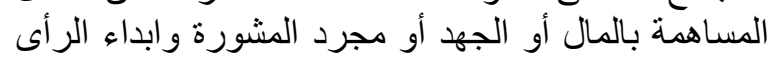
أو الدعاية.

الانغمة الانغماس في الأنشطة الإرشادية: بقصد بدرجة الإنة

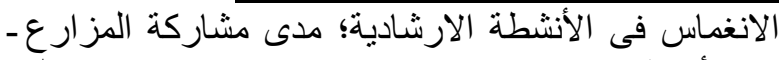

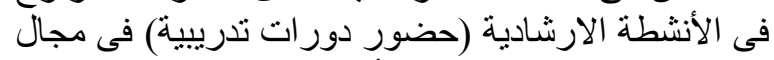

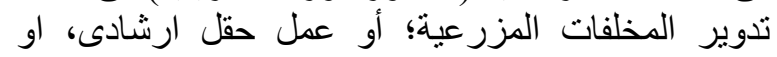

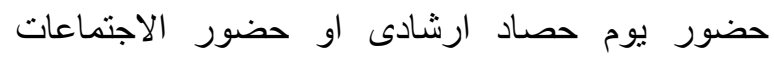

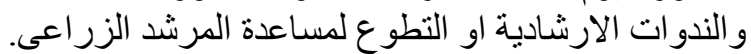

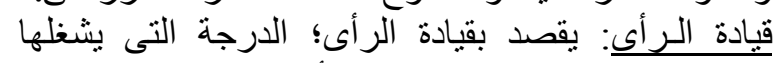

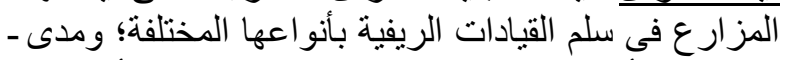

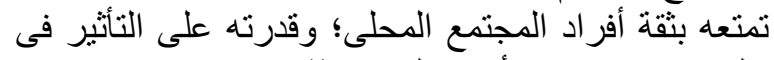
سلوكهم و اقناعهم بالأفكار المستحدثة. 


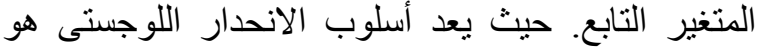

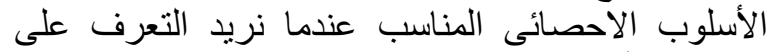

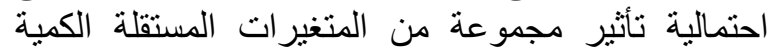

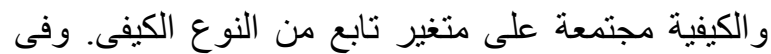

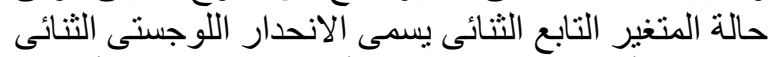
أو Binary حالة متغير تابع من النوع الكيفى ولكن متعدد الفئات

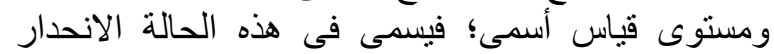

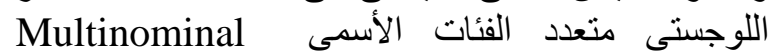

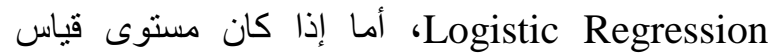
المتغير التابع رتبى؛ ففى هذه الحالة يسمى الانحدار اللوجستى الرنبى Ordinal Logistic Regression. وقد يتم ادخال المتغيرات المستقلة معا مرة واحدة بطريقة

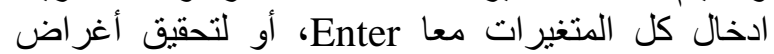

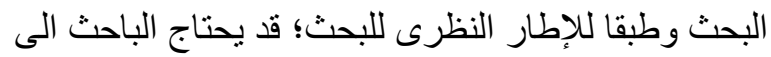

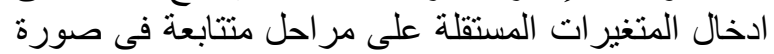

قرار تنبيها. (الإدارة المركزية للارشاد الزراعى، 2011؛

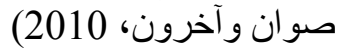
3.2.3 قرار عدم الاستمرار فى تبنى الممارسات الموصى

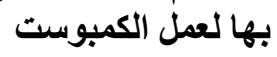

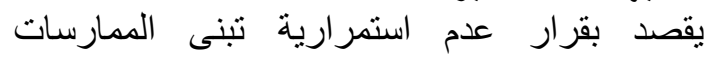

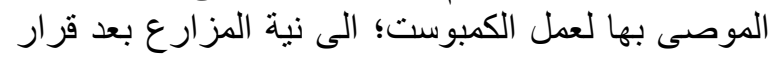

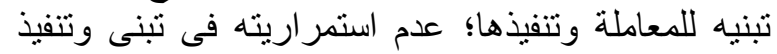

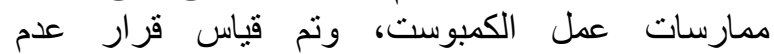

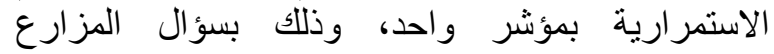

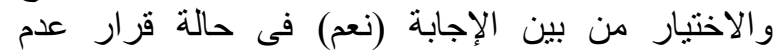

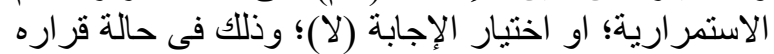

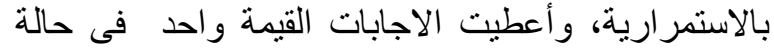

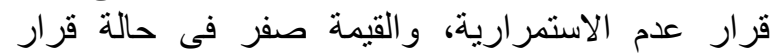

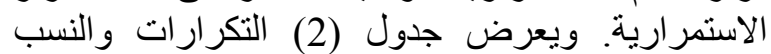

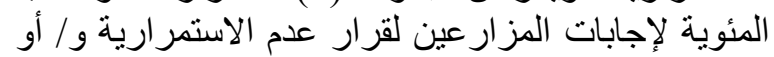

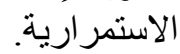

جدول (2): التكرارات والنسب المئوية لقرار عدم استمرارية و/ أو استمرارية الزراع فى تبنى الممارسات الموصى بها لعمل السماد العضوى

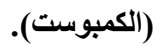

\begin{tabular}{|c|c|c|c|c|}
\hline \multicolumn{2}{|c|}{ قرار الاستمرار } & \multicolumn{2}{|c|}{ قرار عدم الاستمرار } & \\
\hline$\%$ & التكرار & $\%$ & التكرار & \\
\hline 12 & 41 & 88 & 301 & عدم استمر ار / استمر ار تبنى وتنفيذ ممارسات عمل الكمبوست \\
\hline
\end{tabular}

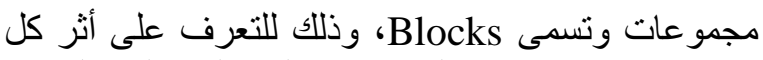

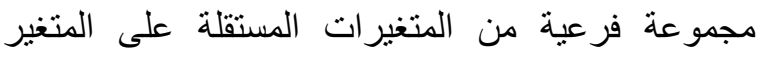

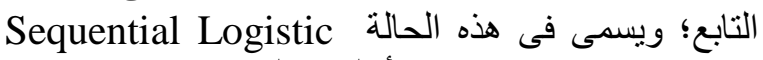
Regression

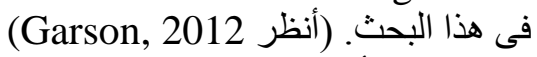
وبعد التأكد من ملائمة البيانات لإجر اء تحليل الإنيل الانحدار

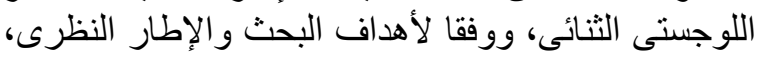

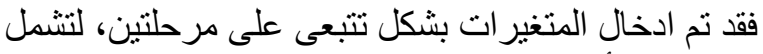

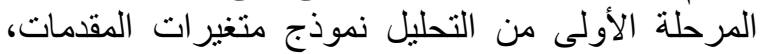

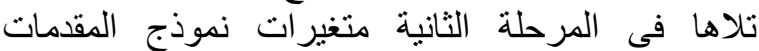

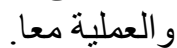

\section{4. النتائج ومناقشتها}

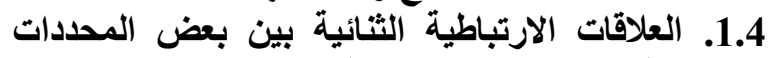

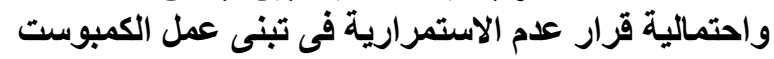

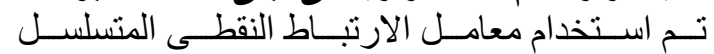
Point- biserial correlation

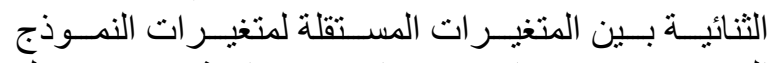

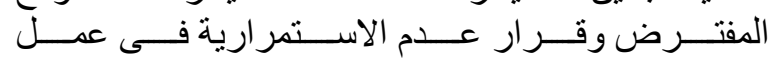

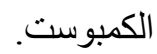

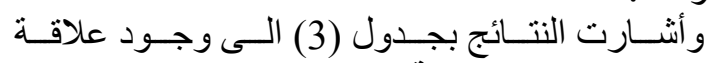

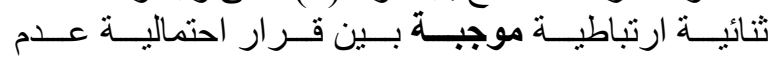

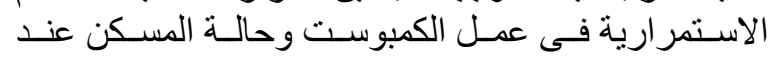

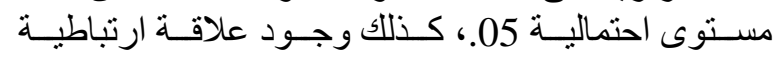

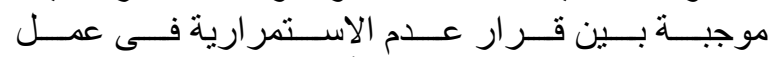

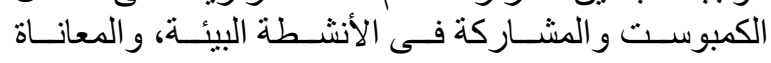

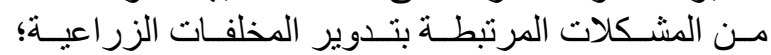

3.3 الطرق والأساليب الاحصائية

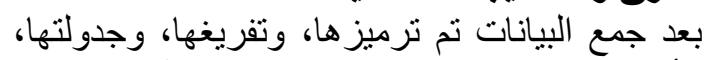

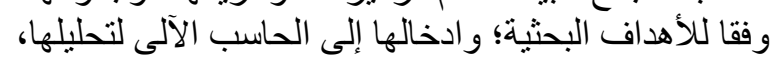

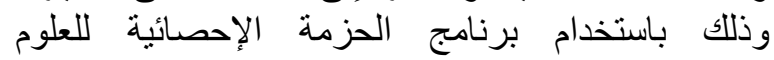
الاجتماعية SPSS الإصدار الثانى والعشرون. Coperation, 2013) الإحصائية الآتية فى التحليل: 1-3-3 حساب التكرارات والنية النسب المئوية والمتوسط

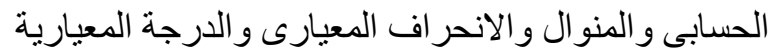
لكتغير ات البحث تبعا لمستوى القياس. 2-3-3 حساب درجة ثبات المقاييس المستخدمة في البحث؛؛

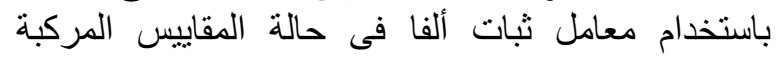

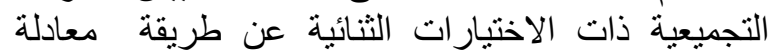

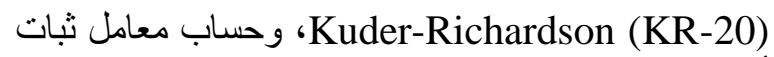
ألفا كورنباخ فى حالة المقاييس المركبة التجميعية ذات الاختيار ات المتعددة.

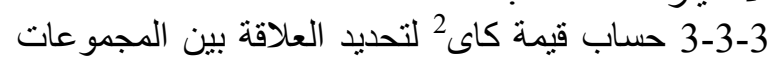

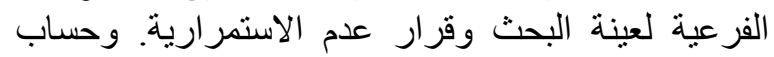
معامل Cramer'sV، لتحديد القوة الاحصائية لهذه العلاقة ولة الإنة

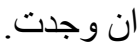

Point- 4-3-3 حساب معامل الارتباط النقطى المتسلسل المئلة و بين المتغيرات المستقلة الكمية

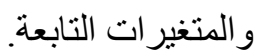
5-3-3 استخدام أسلوب الانحدار اللوجستى الثنائى التتبعى Sequential Binary Logistic Regression واختبار العلاقة بين المتغيرات المستقلة مجتمعة وبين 


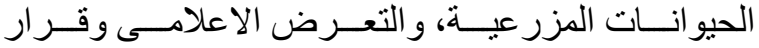

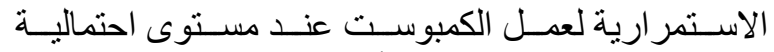

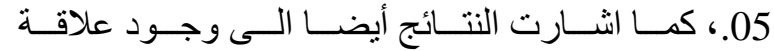

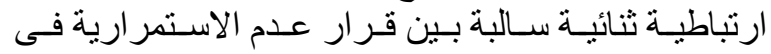

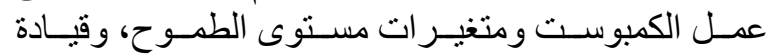

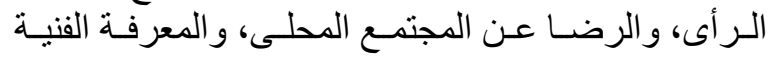

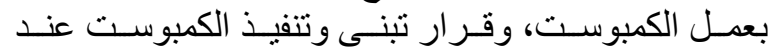

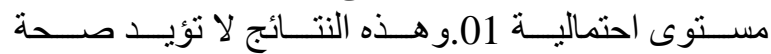

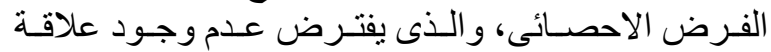

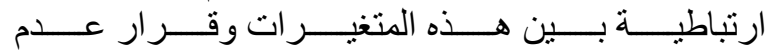

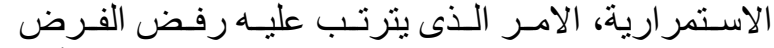

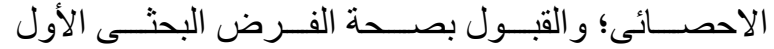

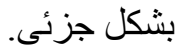

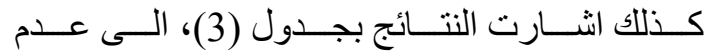

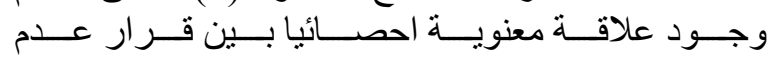

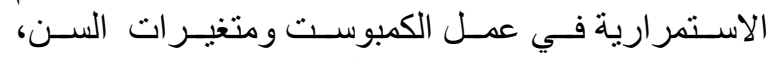

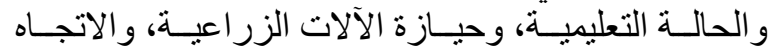

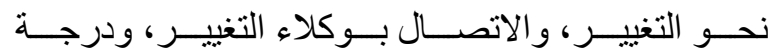

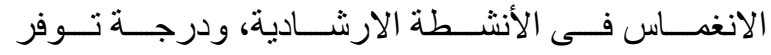

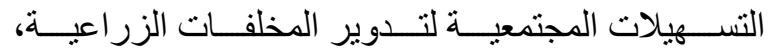

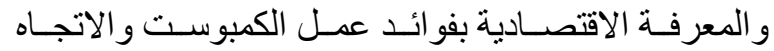

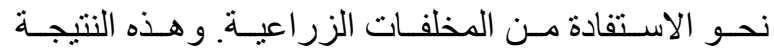

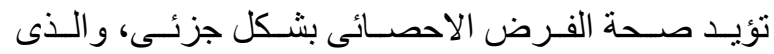

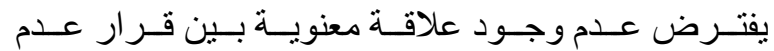

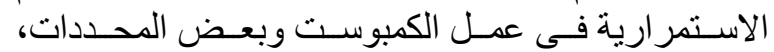

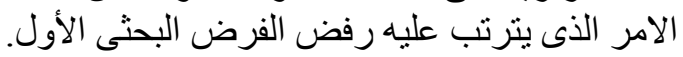

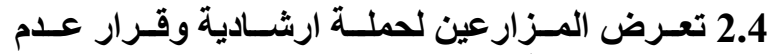

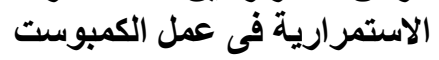

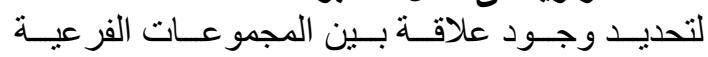

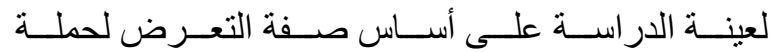

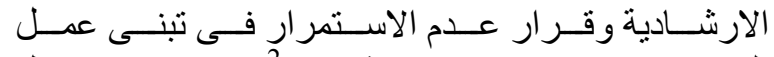

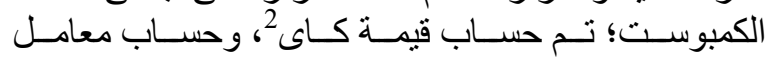
ارتبــاط Cramer's V لاختبـار القــوة الإحصــائية لهذه العلاقة ان وجدت.

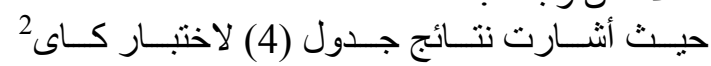

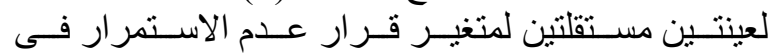

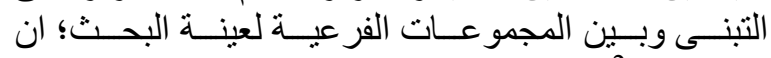

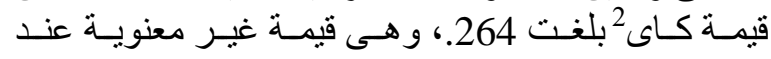

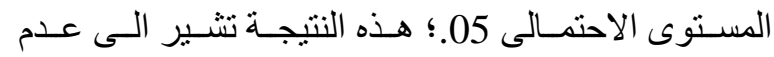

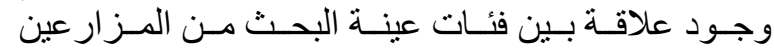

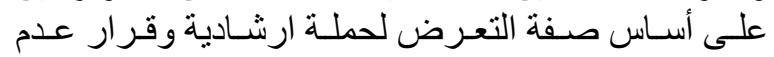
الاستمر ارية فى تبنى عمل الكمبوست.

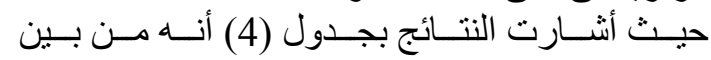

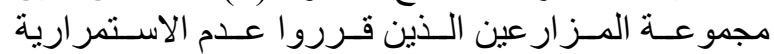

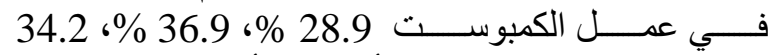

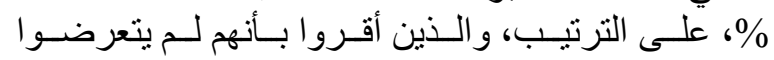

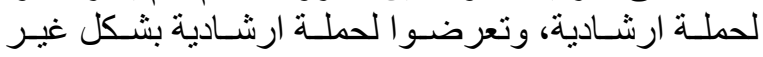
مباثر ، وتعرضو ارنـا لحملة ارشادية بشكل مبانشر .

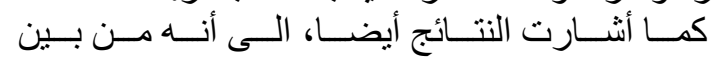

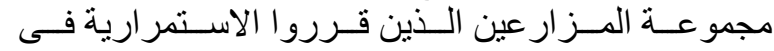

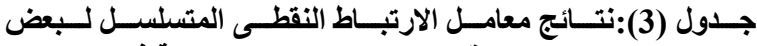

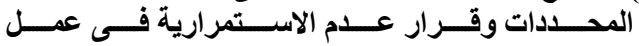

\begin{tabular}{|c|c|}
\hline فى تبنمى عمل الكمبوست الاستمرار & المتغيرات \\
\hline & مقدمات عملية التبنى \\
\hline & متغيرات اجتماعية_اقتصادية \\
\hline-.02 & 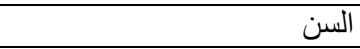 \\
\hline-.04 & الحالة التعليمية \\
\hline $.12 *$ & حالة المسكن \\
\hline$-.13 *$ & مقتنيات المسكن \\
\hline$-.11 *$ & الحيازة الأرضية الزراعية \\
\hline .10 & حيازة الآلات الزر اعية \\
\hline$-.13 *$ & حيازة الحيو انات المزر عية \\
\hline-.01 & الاتجاه نحو التغيير \\
\hline$-.17 * *$ & مستوى الطموح \\
\hline & متغيرات اتصالية \\
\hline$-.11 *$ & التعرض الاعلامى \\
\hline .09 & الاتصال بوكلاء التغيير \\
\hline $.16^{* *}$ & المشاركة فى الأنشطة البيئية \\
\hline 0 & الارشادية الانغماس فى الأنشطة \\
\hline$-.14 * *$ & قيادة الرأى \\
\hline & المحلير كنسق مرتبطة بالمجتمع \\
\hline$-.17 * *$ & الرضا عن المجتمع المحلى \\
\hline .09 & لتدوجير التفخلفات الزيليلات المجتمعية \\
\hline $.18^{* *}$ & الزالاستفادة من تدوير المخلفات المناتة \\
\hline & عملية التبنى \\
\hline & مرحلة المعرفة \\
\hline$-.26 * *$ & المعرفة الفنية بالمعاملة \\
\hline-.02 & المعاملة الاقتصادية بفو ائد \\
\hline & مرحلة الاقتناع \\
\hline .05 & الاتجاه نحو الاستفادة من \\
\hline & المخلفات الزر اعية . \\
\hline & مرحلة قرار التبنى والتنفيذ \\
\hline$-.26 * *$ & قرار تبنى وتتفيذ المعاملة \\
\hline
\end{tabular}

المصدر: جمعت وحسبت من البيانات الميدانية لهذا البحث.

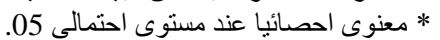
** معنوى احصائيا عند مستوى احتوى احتمالى منى 01.

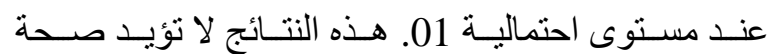

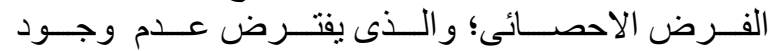

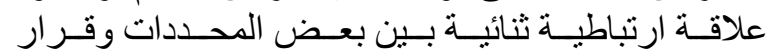

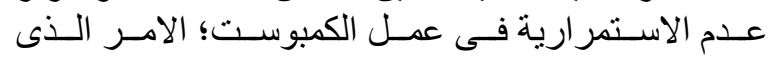
يترتب عليه قبول الفرض البحنَّى الأول بشكل جزئى.

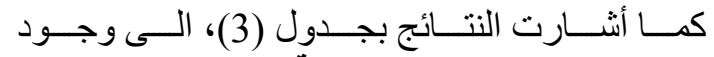

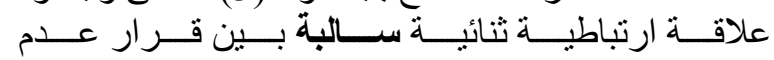

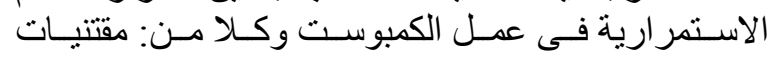

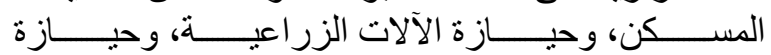




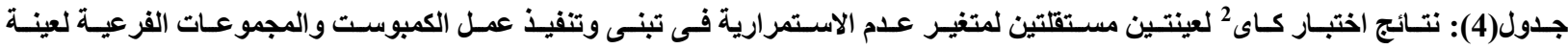

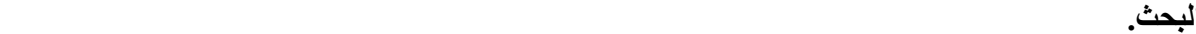

\begin{tabular}{|c|c|c|c|c|c|c|}
\hline \multirow[b]{2}{*}{ المجموع } & \multicolumn{3}{|c|}{ التعرض للحملة الارشادية } & \multirow{2}{*}{\multicolumn{3}{|c|}{ 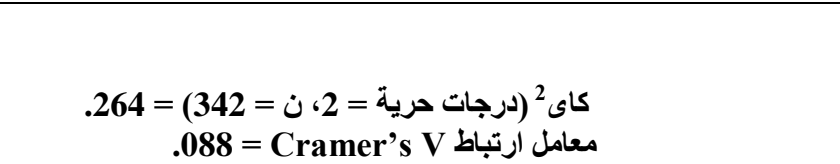 }} \\
\hline & التجموض & التعرض غيورة & مجموعة & & & \\
\hline 301 & 103 & 111 & 87 & الملاحظ & عدم الاستمرارية & \\
\hline $100 \%$ & $34.2 \%$ & $36.9 \%$ & $28.9 \%$ & عدم الاستمرارية/ الاستمر مجمية & & \\
\hline 41 & 18 & 10 & 13 & الملاحظ & & \\
\hline $100 \%$ & $34.9 \%$ & $24.4 \%$ & $31.7 \%$ & عدم الاستمرارية /الاستمر ارية & الاستمرارية & \\
\hline 342 & 121 & 121 & 100 & حجم العينة & & \\
\hline $100 \%$ & $35.4 \%$ & $35.4 \%$ & $29.2 \%$ & عدم الاستمرارية//الاستمرارية بين مجتم & مجموع & \\
\hline
\end{tabular}

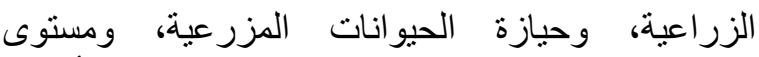

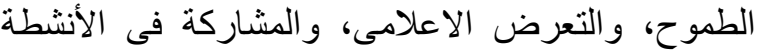

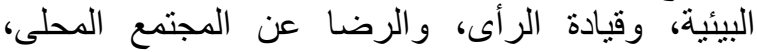

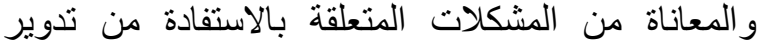

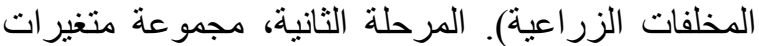

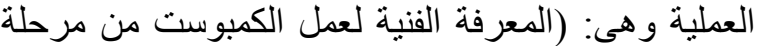
المعرفة، ومرحلة تبنى وتنفيذ عمل الكمبوست). وأشارت نتائج المرحلة الأولى من التحليل؛ أن قيمة كاى2 باستخدام اختبار Omnibus Tests of Model Coefficients (Garson, 2013) المقدمات كانت 79.567 (بدرجات حرية 11، 1342، وحجم عينة 342)، وهى قيمة معنوية عند مستوى احتمالى والتى تثير الى جودة النموذج وقدرته فئه على التمبيز بين

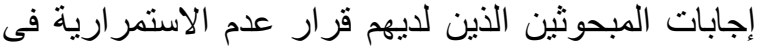

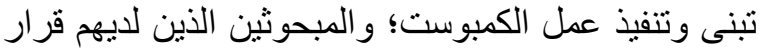
الاستمر ارية فى تبنى وتنفيذ عمل الكمبوست وكئ.

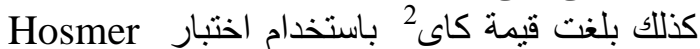
and Lemeshow Test (Hosmer and 4.369 Lemenshow, 1980)

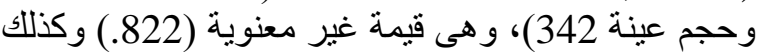

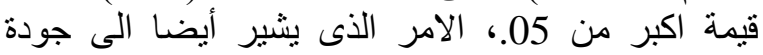
النموذج وقدرته على التمبيز بين إجابات المبحوثين.

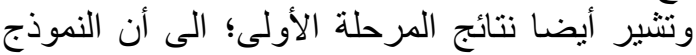

يفسر ما بين 20.8 ٪ طبقا لاختبار Cox and Snell) Square (Cox and Snell, 1989)) (Nagelkerke R Squared (Negelkerke, لاختبار) (1991))

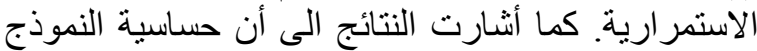
Sensitivity of the model الدقة للأفراد غير المستمرين فى التبنى؛ بينما خصوصية

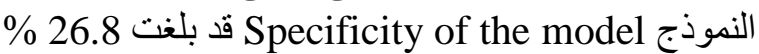
من الافر اد المستمرين والذين تم تحديدهم بشكل صحيح.

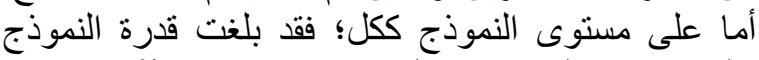
على تصنيف الحالات بشكل صحيح بنسبة 88 \%

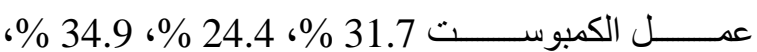

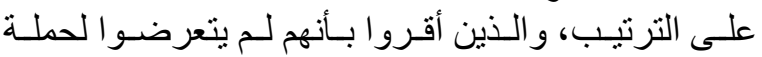

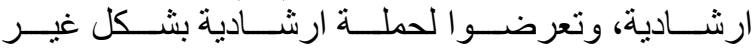

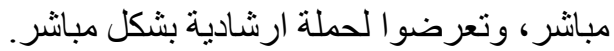

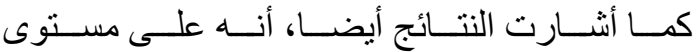

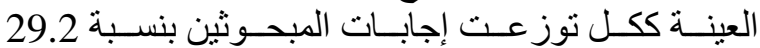

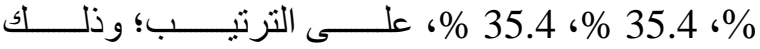

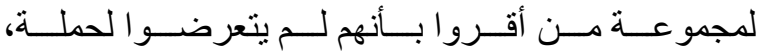

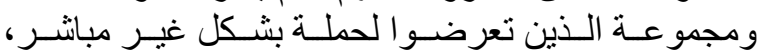

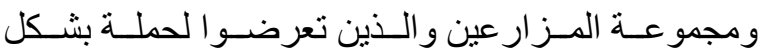
مباشر .

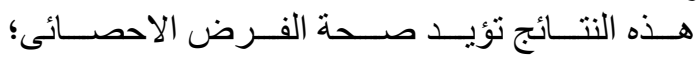

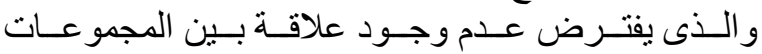

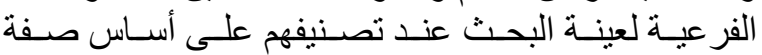

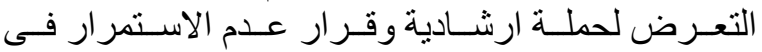

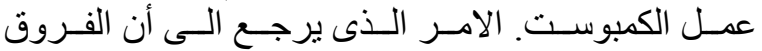

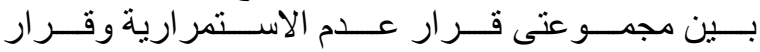

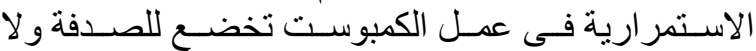

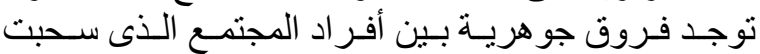

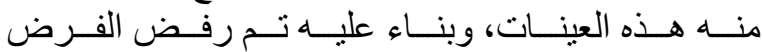

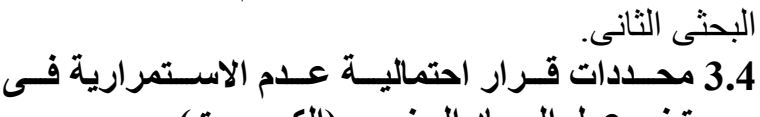
تبنى عمل السماد العضوى (الكمبوست)

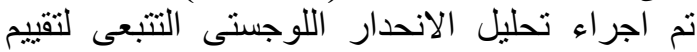

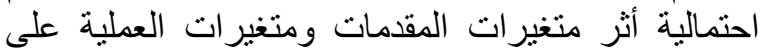

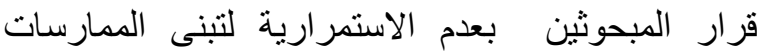

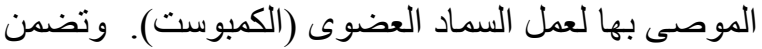

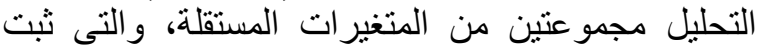

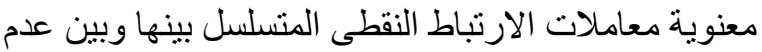

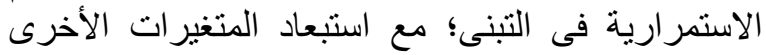

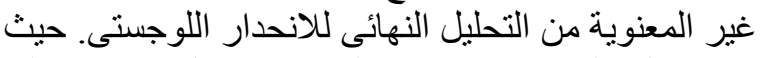

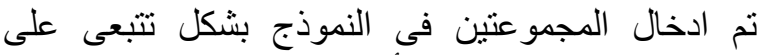
مرحلتين و هما؛ المرحلة الأولى، واشتملت على مجمو عة

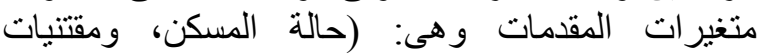
المسكن، و الحيازة الأرضية الزراعية الزية، وحيازة الآلات 
كما أنشارت النتائج بجدول (5)، أن أكبر المتغيرات

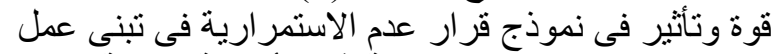
الكمبوست هو متغير المشاركة في الأنشطة البيئية بنسبة

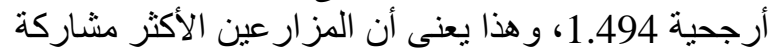

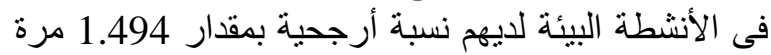

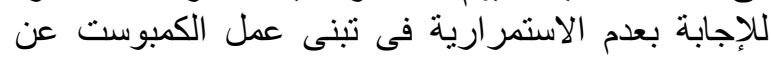

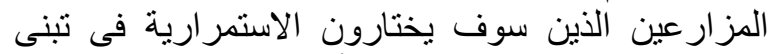

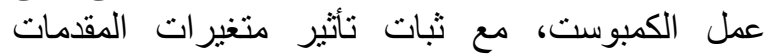
الأخرى فى النموذج. كما كانت أقل المتغيرات قوة ونتأثير فى نموذج قرار

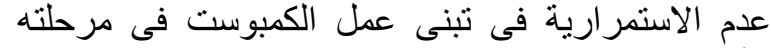

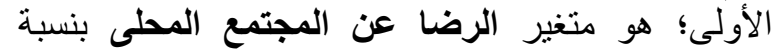

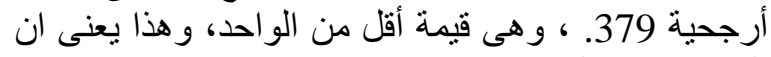

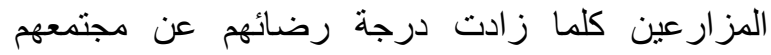

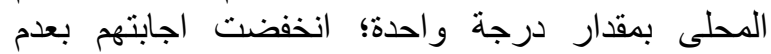

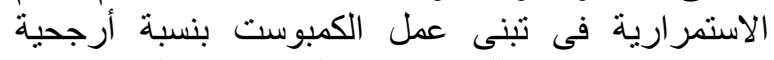

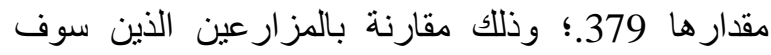

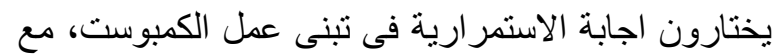

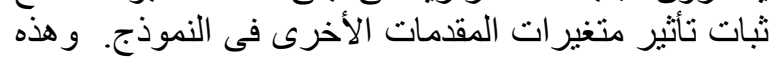

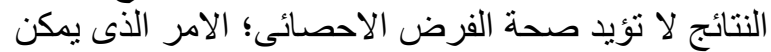
معه قبول الفرض البحثى الثالث. كما أنشارت نتائج المرحلة الثانية من التحليل؛ أن قيمة كاى2 باستخدام اختبار Omnibus Tests of Model Coefficients (Garson, 2013) المقدمات كانت 100.415 (بدرجات حرية 13، 13، وحجم منغيرات

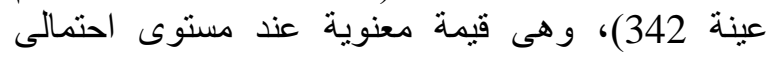

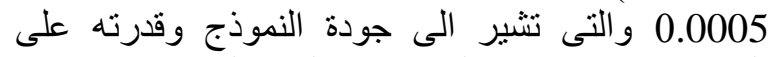

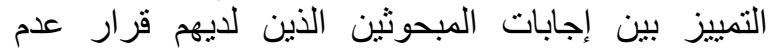
الاستمر ارية فى تبنى وتنفيذ عمل الكمبوست؛ و المبحوثين

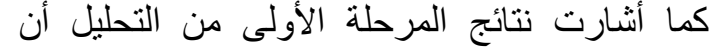

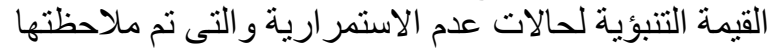

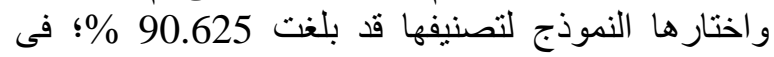
حين كانت القيمة التنبؤية لحالات الاستمر ارية؛ و التى تم

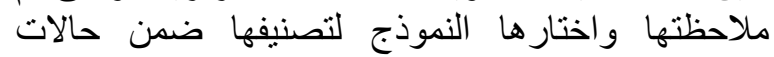
الاستمر ارية مقدار 26.829 \%

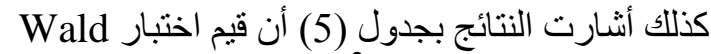

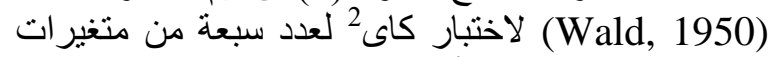

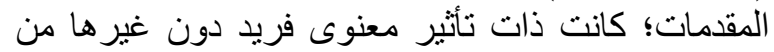

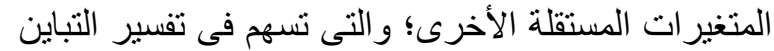
فى النموذج فى مرحلته الاولى وهى: الزئ (حالة المسكن،

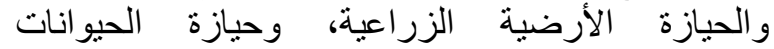

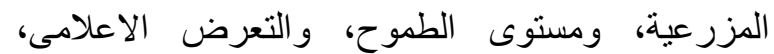

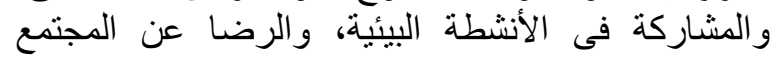

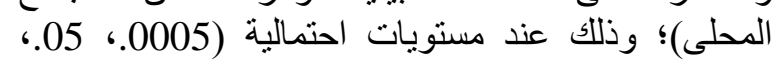

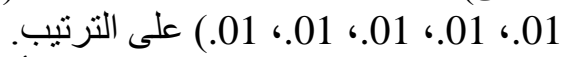

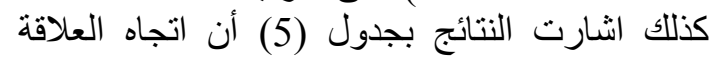

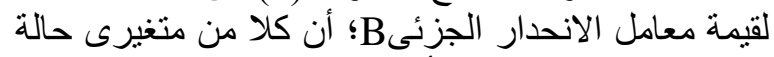

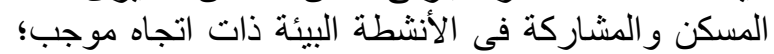

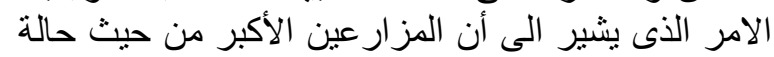

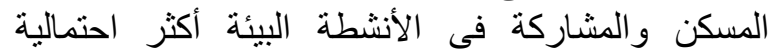

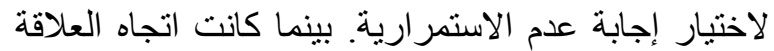

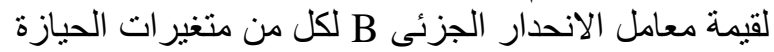

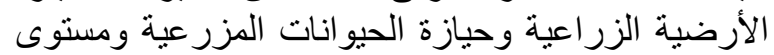

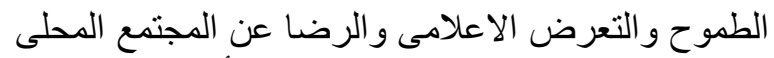

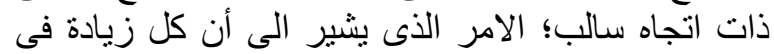

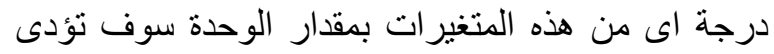

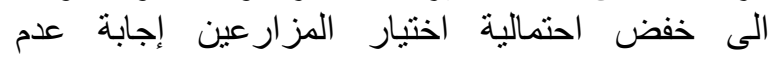

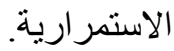

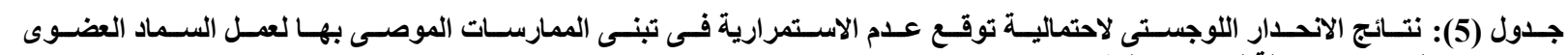

\begin{tabular}{|c|c|c|c|c|c|c|}
\hline \multirow{2}{*}{\multicolumn{2}{|c|}{ 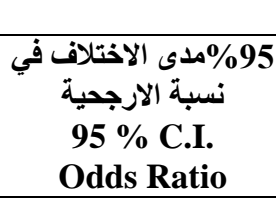 }} & \multirow{3}{*}{ نسبة الارجحية } & \multirow{3}{*}{$\begin{array}{l}\text { قيمة والاية } \\
\text { Sig. }\end{array}$} & \multirow{3}{*}{ 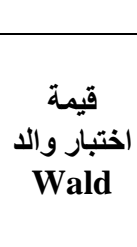 } & \multirow{3}{*}{$\begin{array}{c}\text { الانحدار } \\
\text { الجزئى } \\
\text { B }\end{array}$} & \multirow{3}{*}{ ست) كدالة لمتغيرات } \\
\hline & & & & & & \\
\hline Upper & Lower & & & & & \\
\hline 1.387 & 1.100 & 1.235 & .000 & 12.699 & .211 & حالة المسكن \\
\hline 1.074 & .911 & .989 & .793 & .069 & -.011 & مقتنيات المسكن \\
\hline .999 & .962 & .981 & .041 & 4.173 & -.020 & الحيازة الأرضية الزراعية \\
\hline 1.128 & .957 & 1.039 & .363 & .828 & .038 & حيازة الآلات الزر اعية \\
\hline .943 & .537 & .711 & .018 & 5.630 & -.340 & حيازة الحيوانات المزرعية \\
\hline .828 & .334 & .526 & .005 & 7.716 & -.642 & مستوى الطموح \\
\hline .933 & .715 & .816 & .003 & 8.915 & -.203 & التعرض الاعلامى \\
\hline 1.881 & 1.187 & 1.494 & .001 & 11.664 & .402 & المشاركة فى الأنشطة البيئية \\
\hline 1.159 & .988 & 1.070 & .096 & 2.763 & .068 & قيادة الر أى \\
\hline .832 & .172 & .379 & .016 & 5.842 & -.971 & الرضنا عن المجتمع المحلى \\
\hline 1.178 & .949 & 1.057 & .316 & 1.005 & .055 & تدوير المخلفات المـن المشــكلات المتعلقــة بالاسـتفادة مـن \\
\hline- & - & 9968.404 & .088 & 2.913 & 9.207 & الثابت \\
\hline
\end{tabular}


المحلى و المعرفة الفنية بعمل الكمبوست؛ ذات اتجاه سالب؛

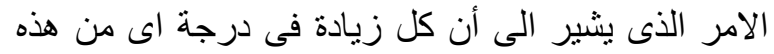

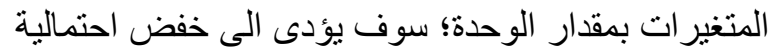
اختيار المزار عين إجابة عدم الاستمر ارية.

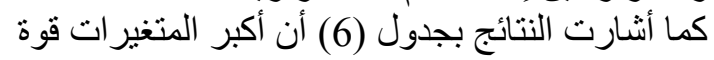

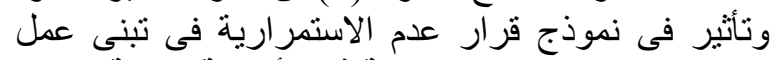
الكمبوست؛ هو متغير المشاركة فى الأنشطة البيئية؛ بنسبة الإنية

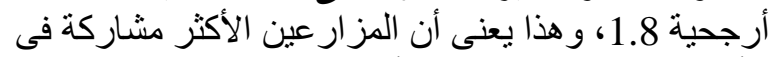

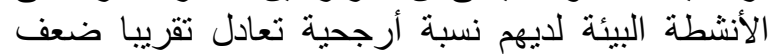

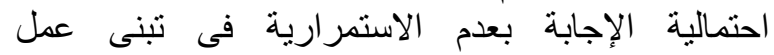

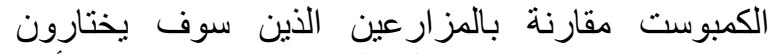

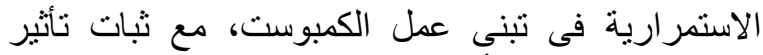
متغير ات المقدمات الأخرى في النموذج النئ

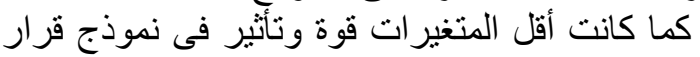

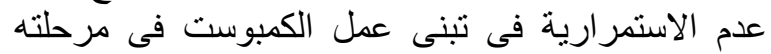

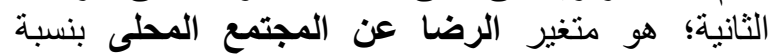

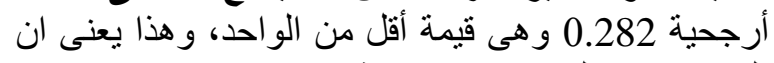

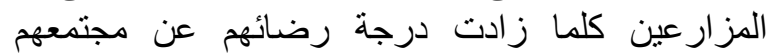

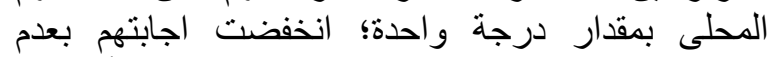

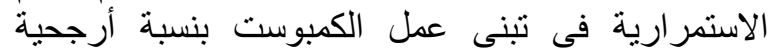

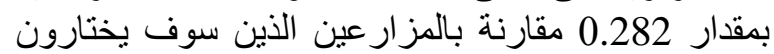

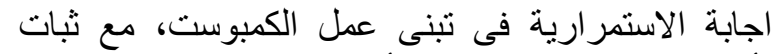

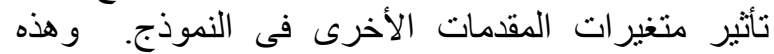

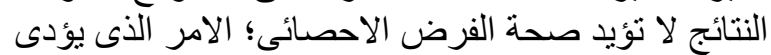
الى قبل الفرض البحنثى الر ابع.

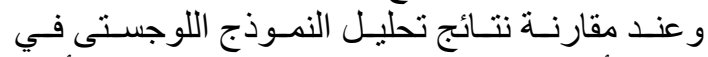

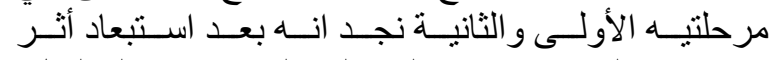

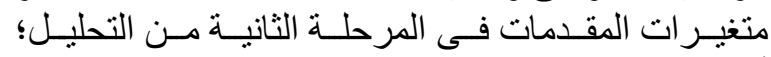

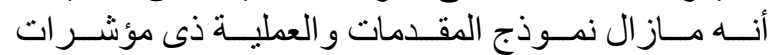

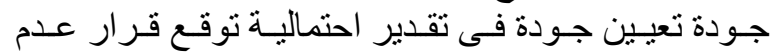

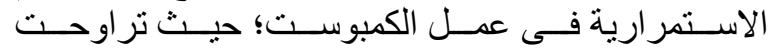

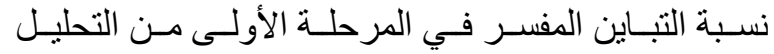

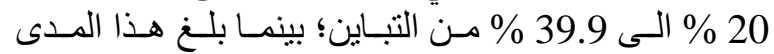

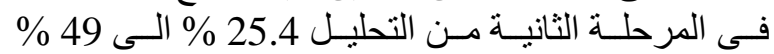

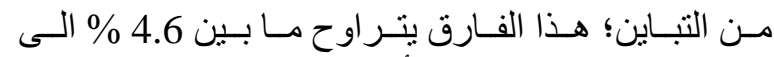

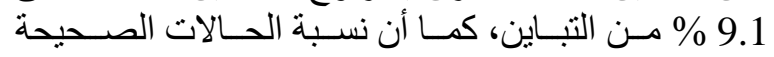

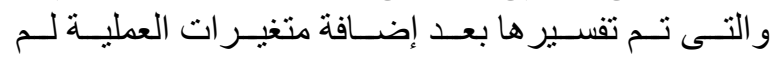

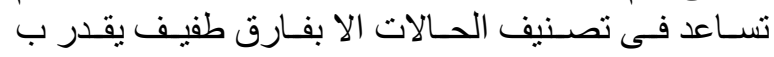

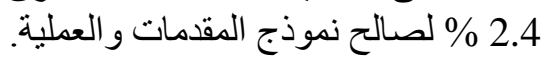

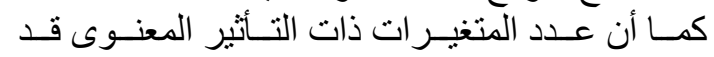

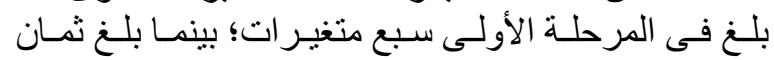

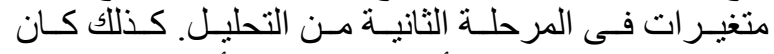

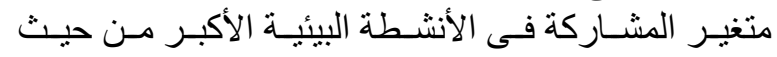

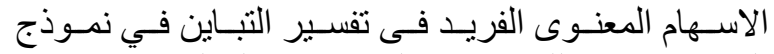

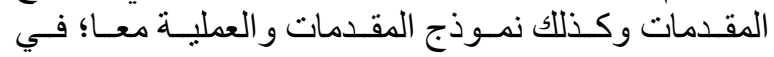

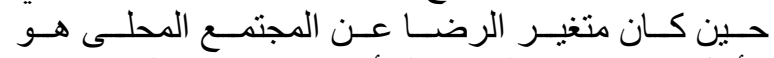

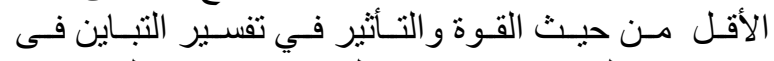

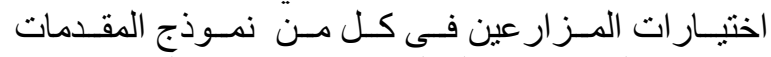

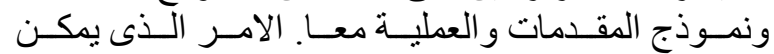

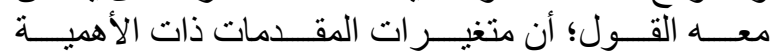

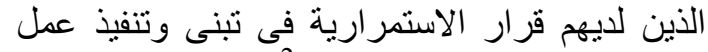

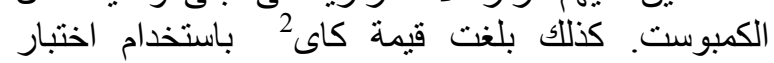
Hosmer and Lemeshow Test (Hosmer and (بدرجات حرية 8) 10.817 Lemenshow, 1980)

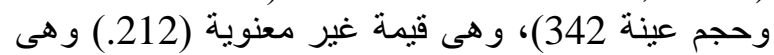

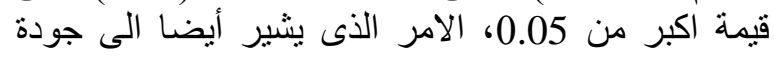

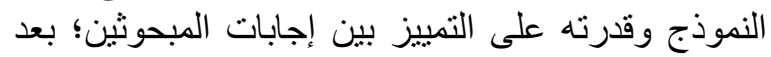
إضافة متغير ات العملية.

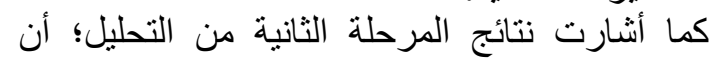

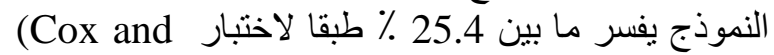
Snell Square (Cox and Snell, 1989)) (Nagelkerke R squared طبقا لاختبار (Negelkerke, 1991)) الاستمر ارية وقرار الاستمر ارية. كما أنشارت النتائج الى لى

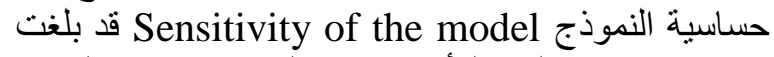
98.7 \% من الدقة للأفراد غير المستمرين فى التنبى؛

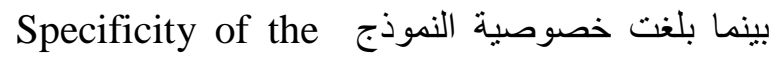
model

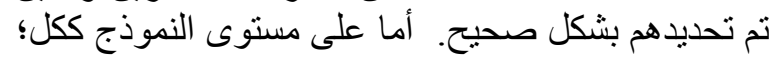

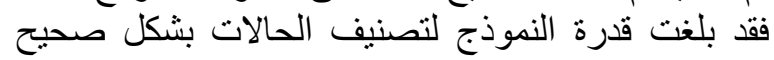
$\% 90.4$

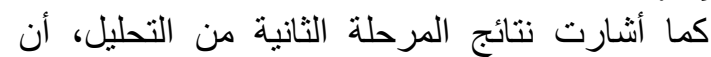
القيمة التنبؤية لحالات عدم الاستمر ارية و التى تم ملاحظتها

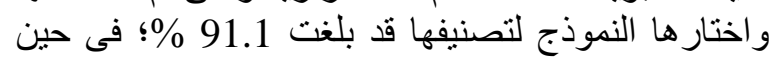

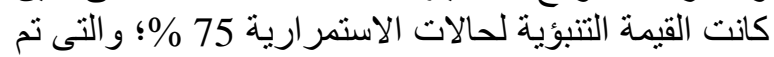

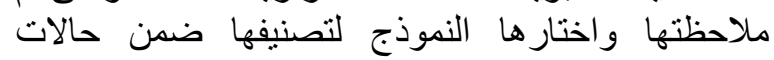

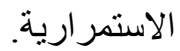

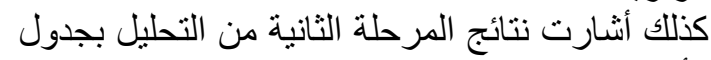

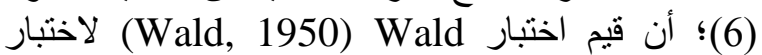

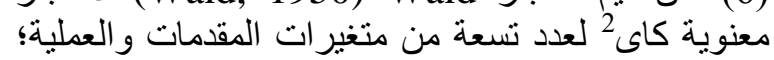

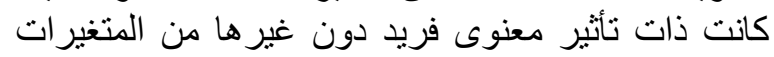

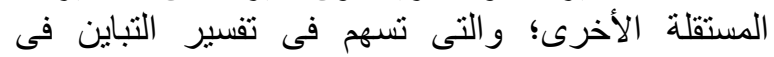

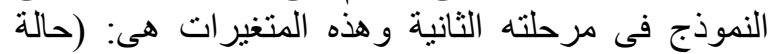

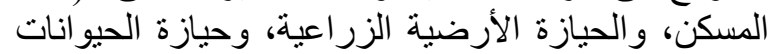

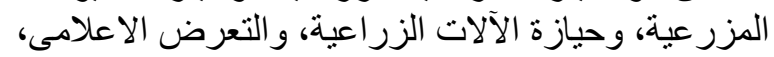

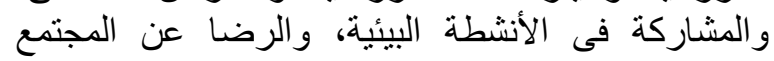

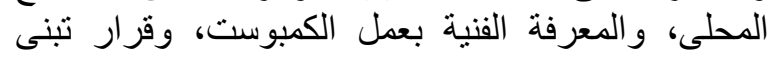

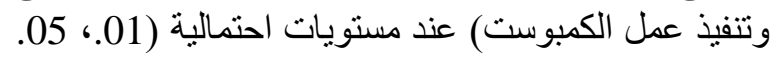

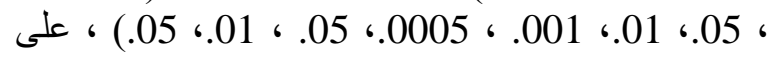
كما اشنارت النتائج بجدول (6)، أن اتجاه العلاقة لقيمة

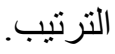

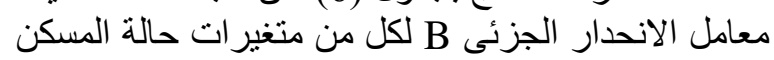
وحيازة الآلات الزراعية واليزئ والمشاركة في الأنشطة البيائية

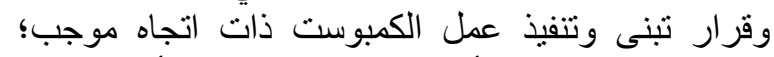

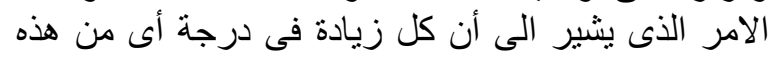

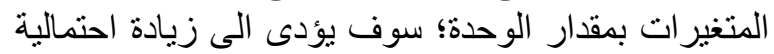

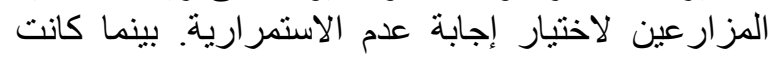

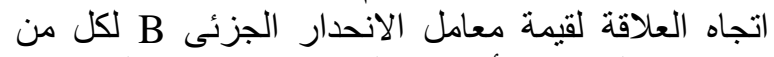

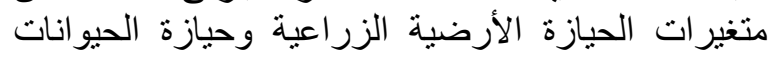

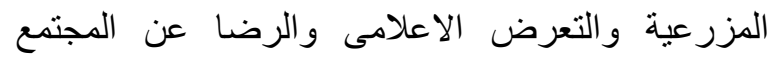




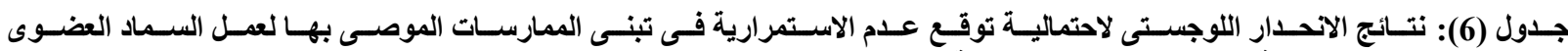
(الكمبوست) كدالة لمتغيرات المقدمات والعات العملية.

\begin{tabular}{|c|c|c|c|c|c|c|}
\hline \multicolumn{2}{|c|}{$\begin{array}{l}\text { نسبة الارجحية الاختلاف في 95 } \\
\text { ف5 C.I. } \\
\text { Odds Ratio } \\
\text { Od }\end{array}$} & \multirow{2}{*}{$\begin{array}{l}\text { الارجبة } \\
\text { Odds } \\
\text { Ratio }\end{array}$} & \multirow[t]{2}{*}{$\begin{array}{l}\text { معنوية قيمة } \\
\text { Sig. }\end{array}$} & \multirow[t]{2}{*}{ 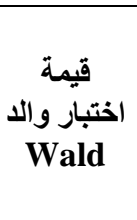 } & \multirow[t]{2}{*}{ الانحدار } & \multirow[t]{2}{*}{ مقدمات وعملية قرار التبنى والتنفيذ } \\
\hline Upper & Lower & & & & & \\
\hline 1.323 & 1.031 & 1.168 & .014 & 5.993 & .155 & حالة المسكن \\
\hline 1.082 & .900 & .987 & .784 & .075 & -.013 & مقتنيات المسكن \\
\hline .998 & .959 & .978 & .035 & 4.434 & -.022 & الحيازة الأرضية الزراعية \\
\hline 1.223 & 1.003 & 1.107 & .044 & 4.050 & .102 & حيازة الآلات الزر اعية \\
\hline .812 & .415 & .581 & .001 & 10.087 & -.544 & حبازة الحيو انات المزرعية \\
\hline 1.160 & .476 & .743 & .191 & 1.709 & -.297 & مستوى الطموح \\
\hline .904 & .671 & .779 & .001 & 10.821 & -.250 & التعرض الاعلامى \\
\hline 2.435 & 1.331 & 1.800 & .000 & 14.567 & .588 & المشاركة في الأنشطة البيئية \\
\hline 1.145 & .968 & 1.053 & .227 & 1.459 & .052 & قيادة الر أى \\
\hline .841 & .094 & .282 & .023 & 5.153 & -1.267 & الرضـا عن المجتمع المحلى \\
\hline 1.166 & .922 & 1.037 & .548 & .361 & .036 & 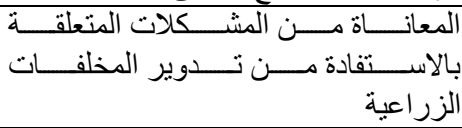 \\
\hline .815 & .337 & .524 & .004 & 8.235 & -.646 & المعرفة الفنية بعمل الكمبوست \\
\hline 2.207 & 1.014 & 1.496 & .042 & 4.117 & .403 & قر ار تبنى وتتفيذ عمل الكمبوست \\
\hline- & - & 1570655 & .056 & 3.649 & 14.267 & الثابت \\
\hline
\end{tabular}

ارتباطا سالبا ومعنويا بقرار عدم الاستمرارية فى تبنى الإنى الإنى

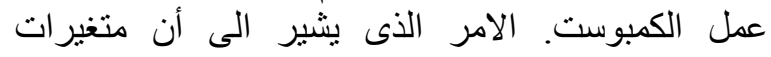
المقدمات متمثلة فى المؤشرات التى التى تعكس المكانة

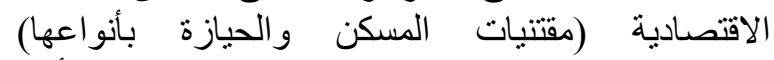

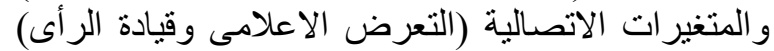

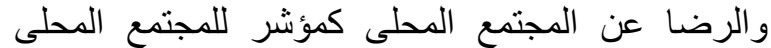

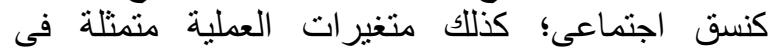

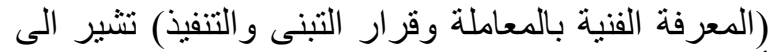

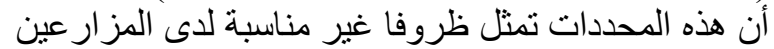

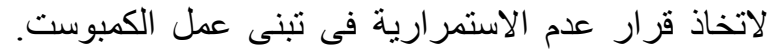

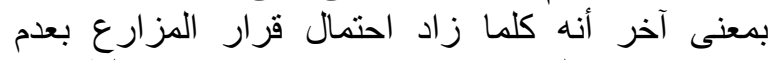

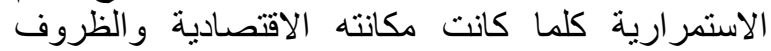
الاتصالية ورضاه عن مجتمعه المحلى كمكان للمعيشة اللفانة منخفضة. و هذه النتيجة قد تتفق مع المنطق النظرى ونتائج

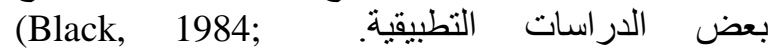
Deutschman and Havens 1964; Jorissen 1969; Leuthold 1965; Leuthold and Wilkening 1965; Leuthold 1967; Silverman and Bailey 1961; Wilkening 1952)

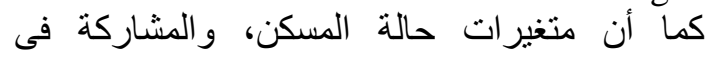

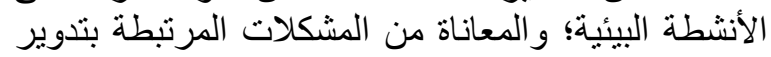

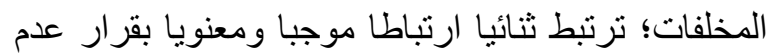

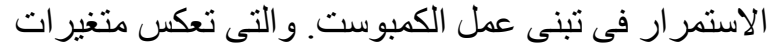

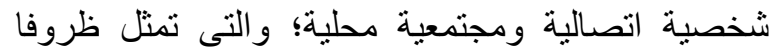

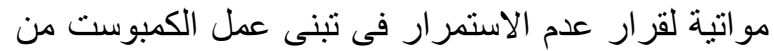

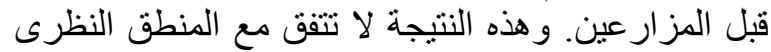

الأكبر فـى تفسير احتماليـة توفـع عدم اسـتمرارية عملـل الكمبوست.

\section{5 الاستنتاجات و المقترحات}

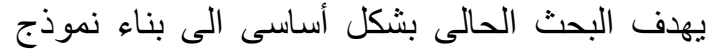

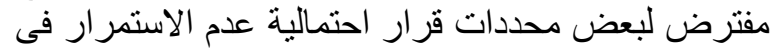

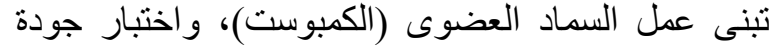

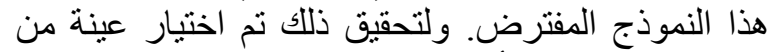

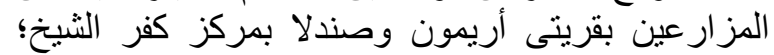

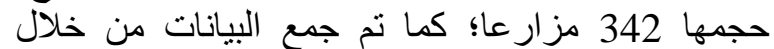

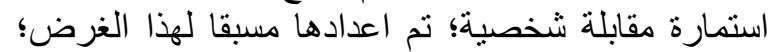

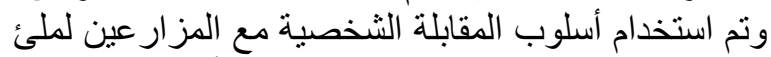
الاستمار ات؛ وذللك فى الفترة من مايو إلى أغسطس الفس الفر 2015

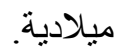

كما تم استخدام العديد من الأساليب الإحصائية لتحليل

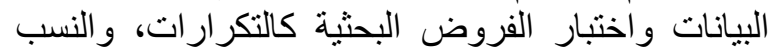

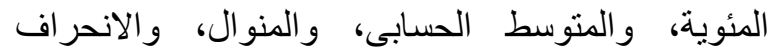

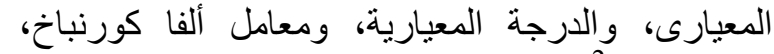
واختبار كاى2'، ومعامل Cramer'sV، ومعامل الإلة الارنباط النقطى المنسلسل، وأسلوب الانحدار اللوجستى الثنائى

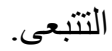

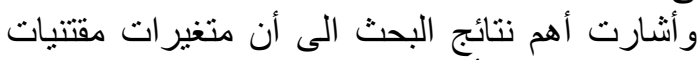

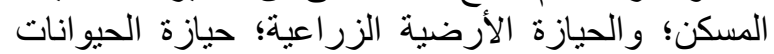

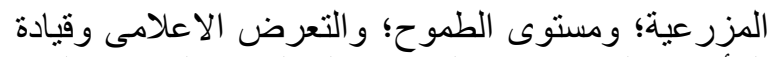

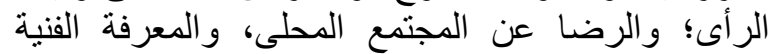
بالمعاملة؛ وقرار تبنى وتنفيذ المعاملة ، ترنبط ثنائيا 
و الاجتماعية الزراعية، جامعة المنصورة، مجلد 4، عدد 1: 107-122. إسماعيل، عبدالخالق على. 12204 (2004). الاحتباجات التدريبية للمرشدين الزراعيين فى مجال إنتاج

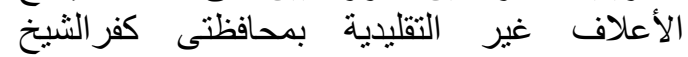
و الدقهلية، مجلة جامعة المنصورة للعلوم الزراعية،

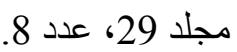
الخولى، حسين ذكى. (1977). الإرشاد الزر اعى ودئ الزوره فى تطوير الريف. دار الكتب الجامعية، القاهرة،

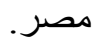

الإدارة المركزية للإرشاد الزراعى. (2011). تدوير اعلاعلاع المخلفات الزراعية لإنتاج أعلاف غير الزير تقليدية،

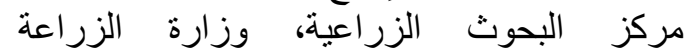
و استصلاح الأراضى، نشرة رقم (694)، الجيزة، مصر . معر الشيخ، عبد السلام. (1996). علم النفس الاجتماعى. دار الفكر الجامعى، الإسكندرية، مصر. (1998.

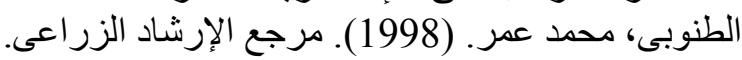

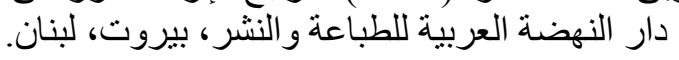

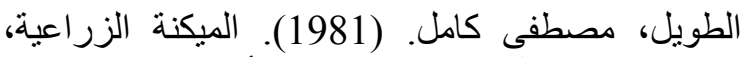

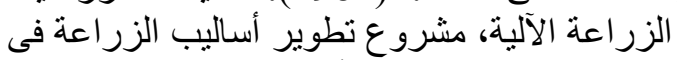

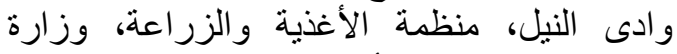

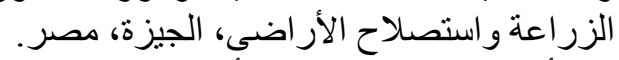

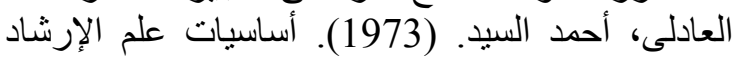
الزراعى. دار المطبو عات الجديدة، الإسكندرية، الإرئاد.

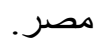
المليجى، محمد حازم عبد المقصود. (2006). استخدام

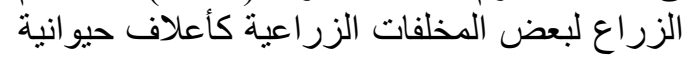
بمحافظة المنوفية، مجلة المنوفية للبحوث الزعاع كاعلاف الزر اعية، مجلد 31، عدد 1.

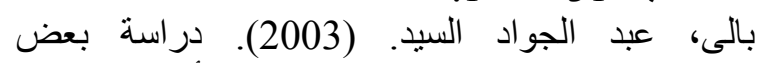

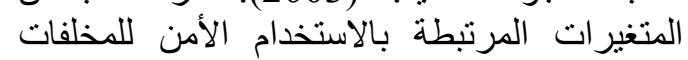

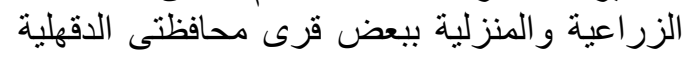
وكفرالشيخ، المجلة المصرية للبحوث الزئة الزراعية، النية

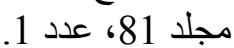
حمدان، داليا إسماعيل إبراهيه. (2005). تبنى الريفيات

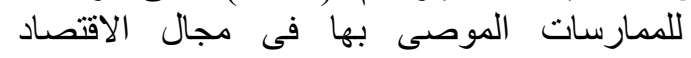

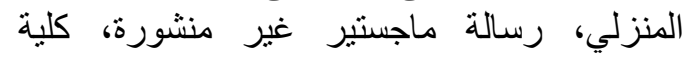

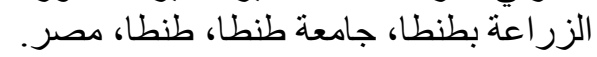

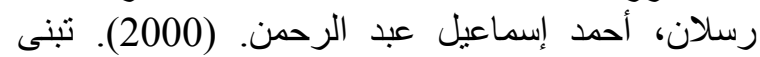

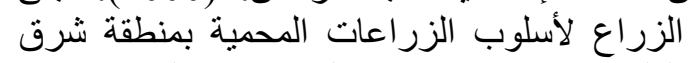

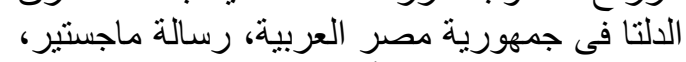

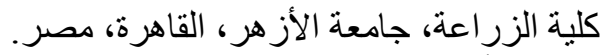

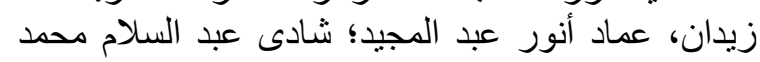

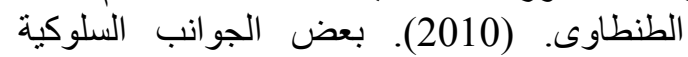
المرتبطة باستخدام وتصنيع الزراع للأعلاف غير البراف

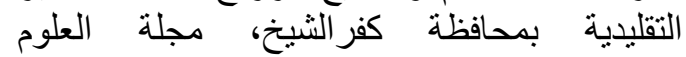
الاقتصادية و والاجتماعية الزية الزراعية، المنصورة، مجلد 1، عدد 5: 435- 458.

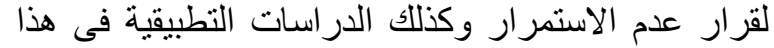

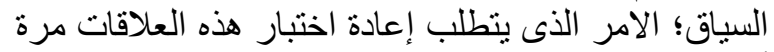

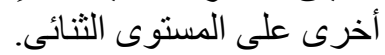

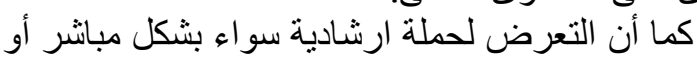

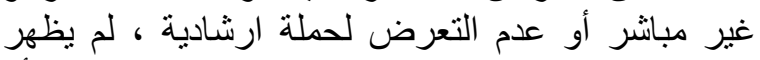

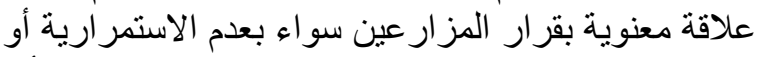

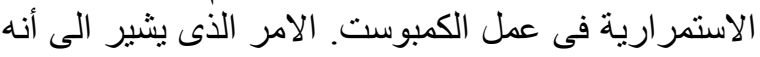

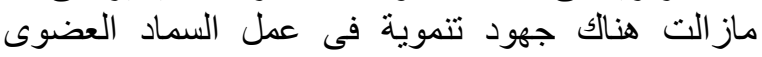

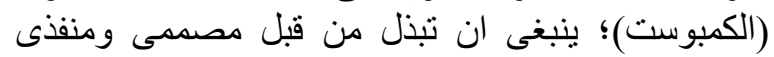

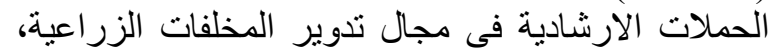

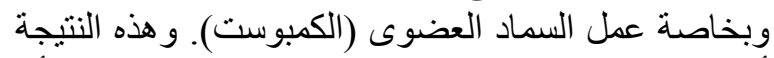

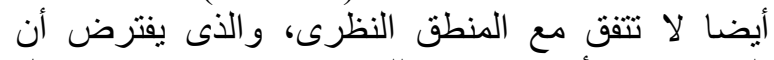

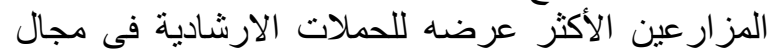

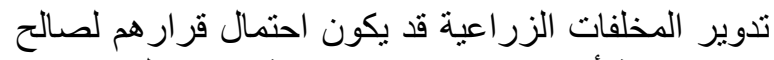

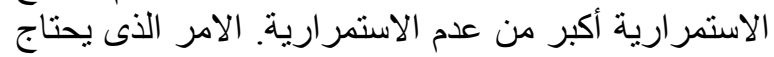

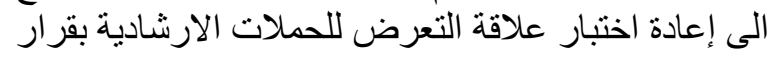

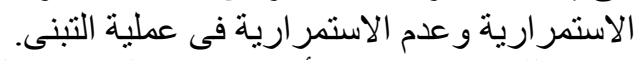

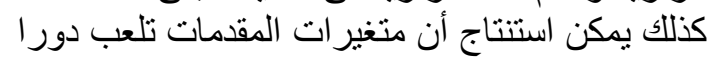

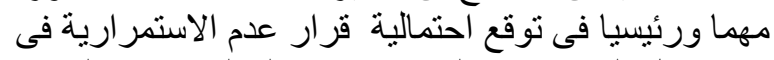

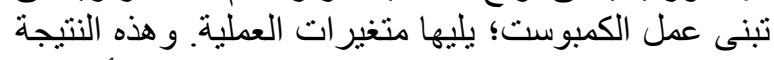

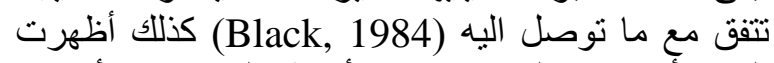

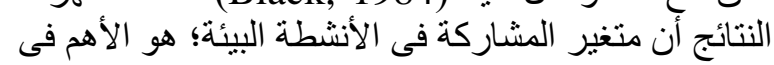

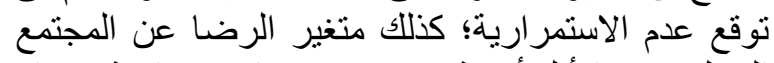

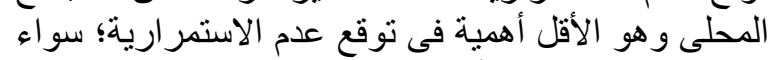

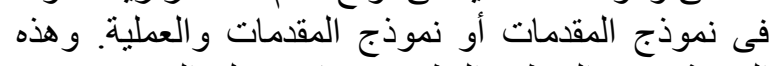

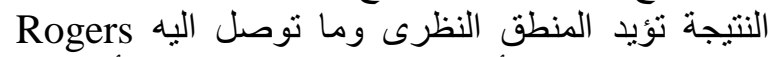

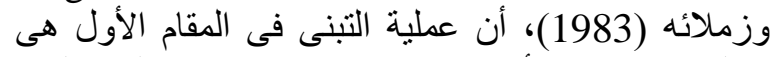

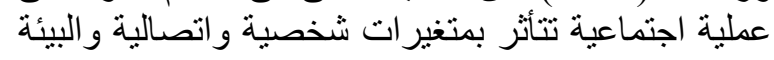

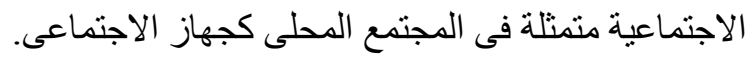

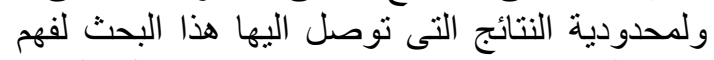

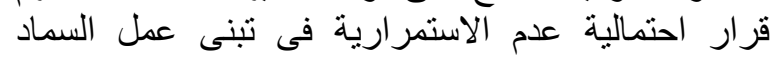

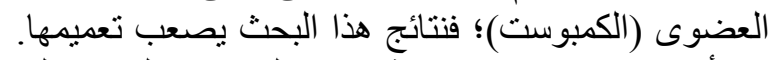

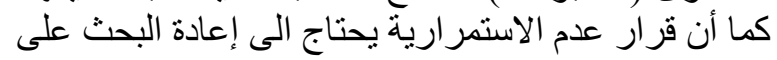

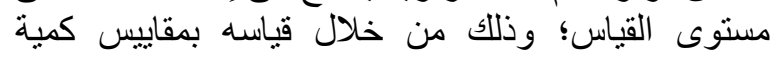

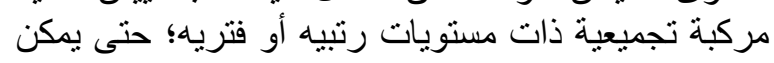

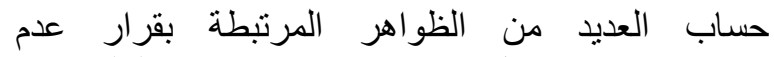

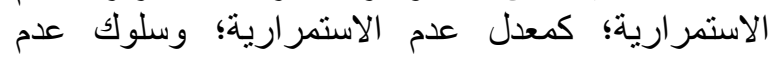

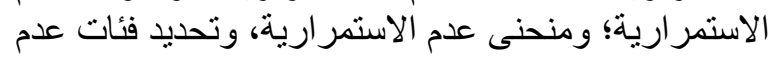

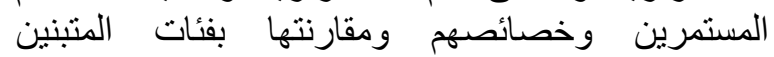

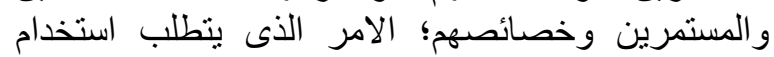

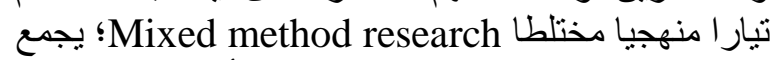
بين المنهج الكمى والمنهج النوعى؛ لفهم أفضل لقرار عدم

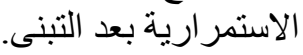

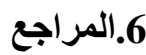

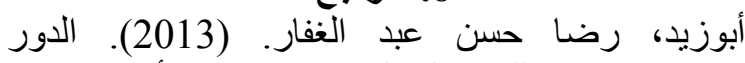
الإرشادى للقادة المحليين فى إنتاج الأعلاف غير الإن

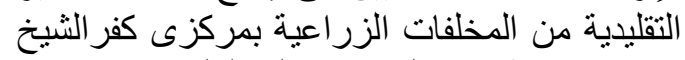

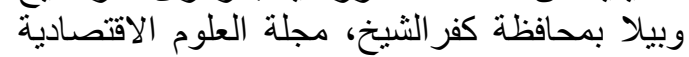


الزراعى، كلية الزراعةـ جامعة القاهرة، الجيزة، مصر.

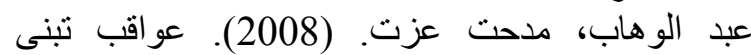

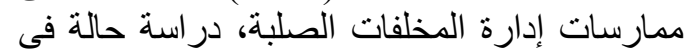

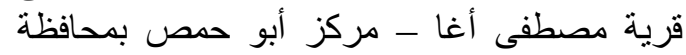

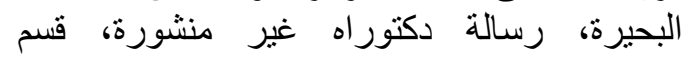

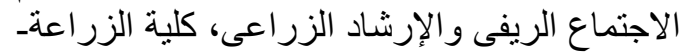
جامعة القاهرة، الجيزة، مصر. الإنشاد الزراعر عثمان، إيمان ماهر. (2009). تبنى الميزة المرأة الريفية

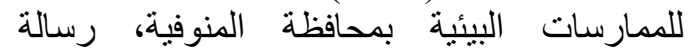
ماجستير، كلية الزراعة-جامعة المنوفية، شبية الكبين

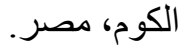
على، فكرى كمال كامل. (2005). الاحتياجات المعرفية لزراع محصول المشمش بقرية العمار بمحافظة المانة

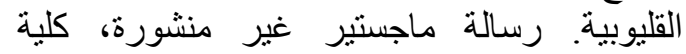

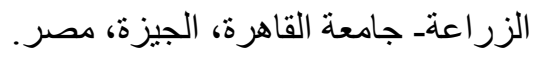

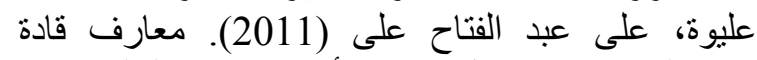

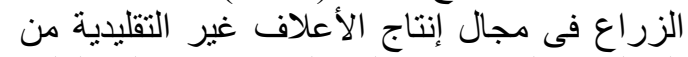

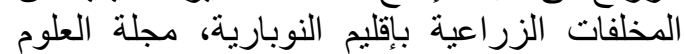

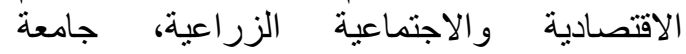
المنصورة، مجلد 2، العدد 5: 389-395.

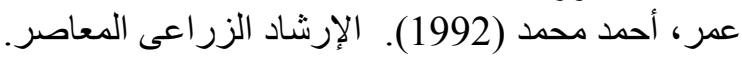

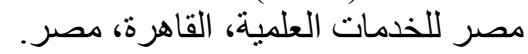

محمد، خديجة مصطفى، عبد الحليم ، حنانة القان كمال

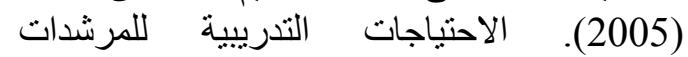

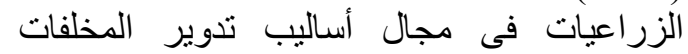

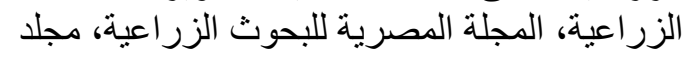

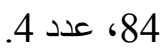

مدكور، طه منصور، و و أميل صبحى ميخائيل. (2001).

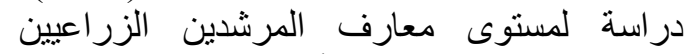

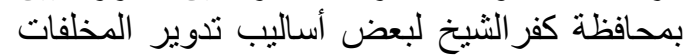

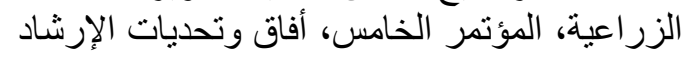

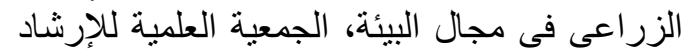
الزراعى، 24-25 إبريل، القاهرة، مصر.

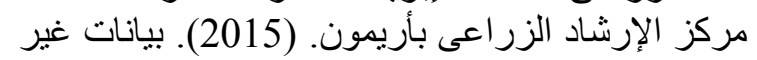

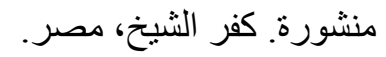

هليل، هدى مصطفى حماده. (2017). قرار لثنى استمرار

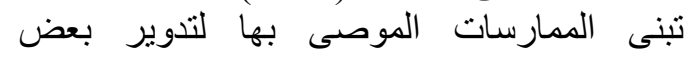

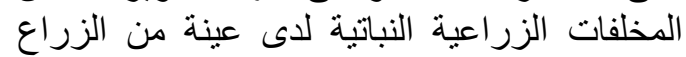

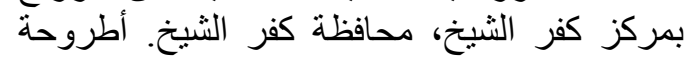

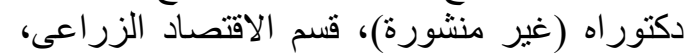
كلية الزر اعة - جامعة طنطا، طنطا، مصر. وهبة، أحمد جمال الدين. (1990). دراسة الزية اجتماعية

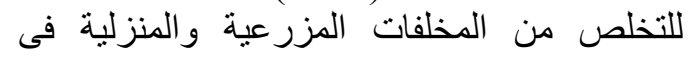

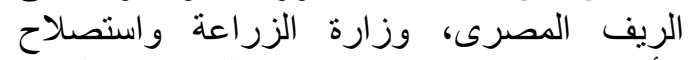

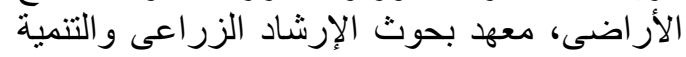

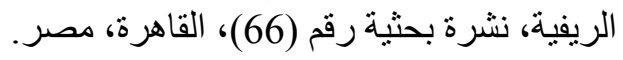

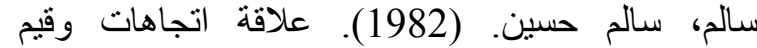

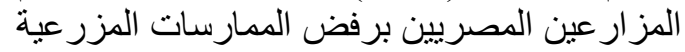

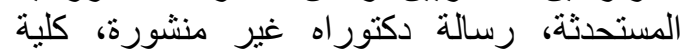

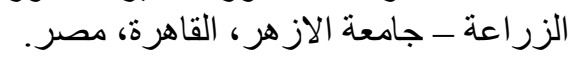

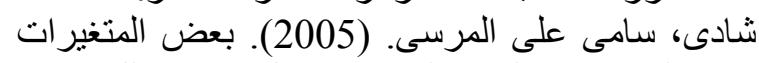

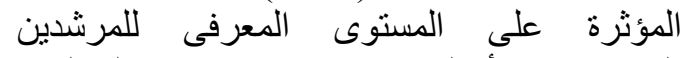

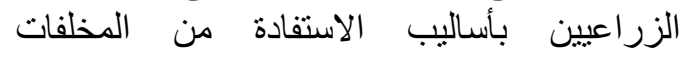

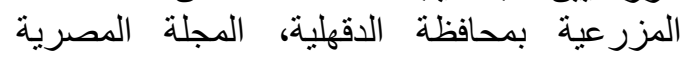
للبحوث الزر اعية، مجلد 83، عدة عدد 4.

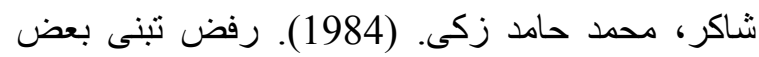

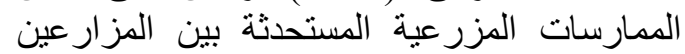

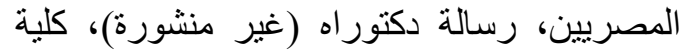

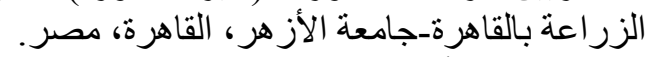

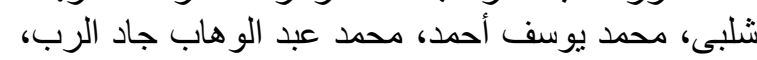

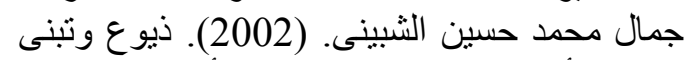

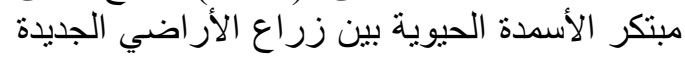

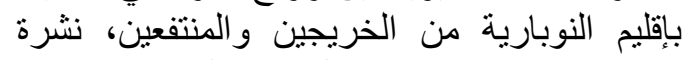

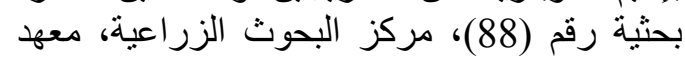
بحوث الإرشاد الزراعي والتركية البتمية الريفية، الجيزة،

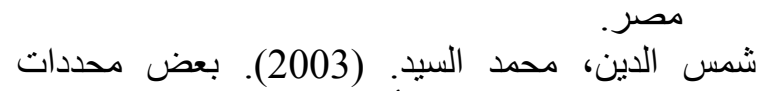
المستوى المعرفى بأساليب الاستفادة من تدوئ مندير

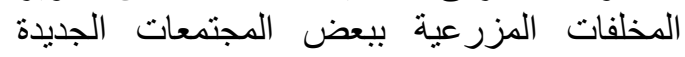

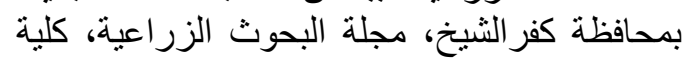
الزراعة بكفر الثيخ، جامعة طنطا، مجلد 29، لزعل، عدد . 2

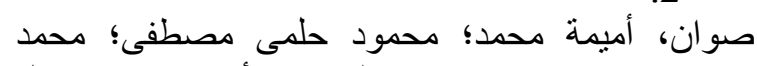

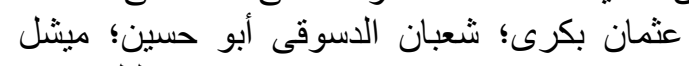

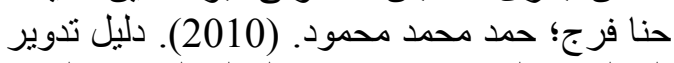

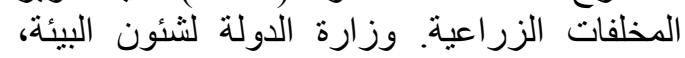

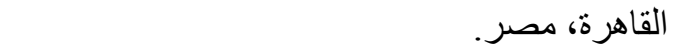

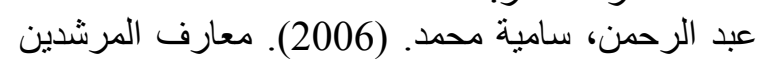

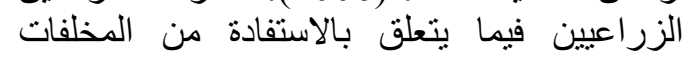

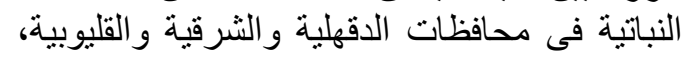
مجلة العلوم الزراعية، جامعة المنصورة النّة، مجلد

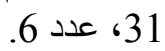

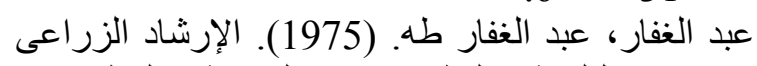

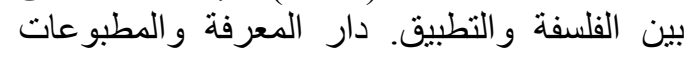
الجديدة، الإسكندرية، مصر. عبد اللا، مختار محمد. (2014). تبنى ولئى و انتشار المحدثات

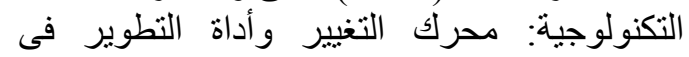

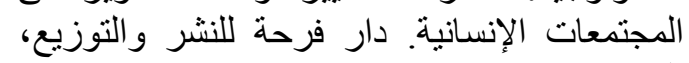

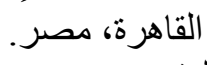
عبد المقصود، بهجت محمد. (1988). الإرشاد الزراعى. دار الوفا للطباعة والنشر و التوزيع، المنئ، المنصورة، عبد الوهاب، مدحت عزت. (2003). تبنى زراع الأرز

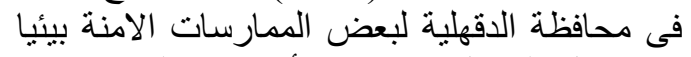

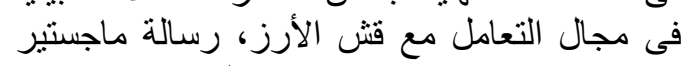

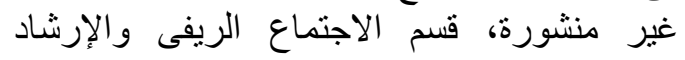




\section{REFERENCES}

Bishop R. and Coughenour C. M. (1964). Discontinuance of farm innovations. Department of Agricultural Economics and Rural Sociology, Ohio State University, Departmental Series, A.E. 361.

Black W. (1984). Discontinuance and diffusion: Examination of the post adoption decision process. Adv. Cons. Res., 10: 356-361.

Cox D.R. and E.J. Snell .(1989). Analysis of binary data. Second Edition. Chapman and Hall, London, UK.

DeFleur M. L. (1966). Mass communication and social changes. Soc. Forces, 44: 314-96.

Deutschman P. J. and Havens A. E. (1964). Discontinuance: A relatively uninvestigated aspect or diffusion (San Jose, Costa Rica: Programs InterAmericano de Information Popular).

Garson D. (2012). Logistic regression: Binary and multinomial. Statistical Associates Publishing. Blue Book Series.

Hosmer D. W. and Lemeshow S. (1980). Goodness-of-fit tests for the multiple logistic regression model. Communications in Statistics-Theory and Methods 9: 1043-1069.

IBM Corporation. (2013). IBM SPSS statistics for windows, Version 22.0. Armonk, New York, USA: IBM Corporation.

Johnson D. E. and van den Ban A. (1959). The dynamics or farm practice change. Paper presented to the Midwest Sociological Society, Lincoln, Nebraska, USA.

Jorissen M. W. (1969). Discontinuance of innovations by farmers in Minas Gerais. Brazil, unpublished M.A. thesis (Lansing: Michigan State University) .

Leagans J.P. (1961). Characteristics of teaching and learning in extension education, extension education in community development, Directorate of extension, Government of India, New Delhi, India.
Leuthold F. O. (1965). Communication and diffusion or improved farm practices in two northern Saskatchewan farm communities (Saskatoon, Canada, Saskatchewan: University Campus, Center for Community Studies.

Leuthold F. O. (1967). Discontinuance of improved farm innovations by Wisconsin farm operators (Ph.D. dissertation). Madison, RS(E): University of Wisconsin. Leuthold F. O. and Wilkening E. A. (1965). Measuring the dimensions or the adoption process and assessing the factors associated with the acceptance and continued ese of new farm technology. Paper presented at the Midwest Sociological Society, Minneapolis.

Nagelkerke N.J.D. (1991) "A note on a general definition of the coefficient of determination.” Biometrika 78: 691-692.

Rogers E.M. and Shomaker F.F. (1971). Communication of innovations, second edition, New York, USA: The Free Press, p. 102-117.

Rogers E.M. (1983). Diffusion of innovations. The Free Press. Third editions. A Division of Macmillan Publishing Co., Inc., New York, USA.

Ryan B. and Gross, N. (1943). The diffusion of hybrid seed corn in two Iowa communities. Rural Sociology, Vol. 8, Pp. $15-24$.

Silverman L. J. and Bailey, W. C. (1961). Trends in the Adoption of Recommended Farm Practices, Alcorn County, Mississippi, 1954-1957 (Mississippi Agricultural Experiment Station Bulletin 617, April.

Wald A. (1950). Statistical decision functions. John Wiley and Sons, New York, USA.

Wilkening E. A. (1952). Acceptance of improved farm practices. (Raleigh: North Carolina Agricultural Experiment Station Technical Bulletin 98). 